\title{
Click Synthesis, Anticancer Activity, and Molecular Docking Investigation of some Functional 1,2,3-triazole Derivatives
}

\author{
Meryem Hrimla ${ }^{1, *(\mathbb{C})}$, Ali Oubella ${ }^{2}(\mathbb{D})$, Yassine Laamari ${ }^{2}$, Lahoucine Bahsis ${ }^{1,3, * \mathbb{C}}$, Adib Ghaleb ${ }^{1}{ }^{(\mathbb{D}}, \mathrm{My}$ \\ Youssef Ait Itto $^{2(\mathbb{C})}$, Aziz Auhmani ${ }^{2(\mathbb{D})}$, Hamid Morjani ${ }^{4(\mathbb{C})}$, Miguel Julve ${ }^{5(\mathbb{1})}$, Salah-Eddine Stiriba ${ }^{5(\mathbb{D})}$
}

1 Laboratoire de Chimie Analytique et Moléculaire /LCAM, Université Cadi Ayyad, Faculté Polydisci-plinaire de Safi, Sidi Bouzid.B.P. 4162, 46000 Safi, Morocco; meryemhrimla.uca@gmail.com (M.H.); adib.ghaleb@gmail.com (A.G);

2 Laboratoire de Synthèse Organique et Physico-Chimie Moléculaire, Département de Chimie, Faculté des Sciences, Semlalia, B.P 2390, Marrakech, 40001, Morocco ; oubellaali1@gmail.com (A.O.); yassine.laamari@edu.uca.ac.ma (Y.L.); aititto@uca.ac.ma (M.Y.A.I); a.auhmani@uca.ac.ma (A.A.);

3 Laboratoire de Chimie de Coordination et d'Analytique, Département de Chimie, Faculté des Sciences d'El Jadida, Université Chouaïb Doukkali, B.P. :20, El Jadida 24000, Morocco; bahsis.lahoucine@ gmail.com (L.B.);

4 BioSpectroscopieTranslationnelle, BioSpecT - EA7506, UFR de Pharmacie, Université de Reims Cham-pagne-Ardenne, 51 Rue Cognacq Jay, 51096, Reims Cedex, France; hamid.morjani@univ-reims.fr (H.M.);

5 Instituto de Ciencia Molecular/ICMol, Universidad de Valencia, C/ Catedrático José Beltrán 2, 46980, Valencia, Spain; miguel.julve@uv.es (M.J.).; stiriba@uv.es (S.-E.S.);

* Correspondence: meryemhrimla.uca@gmail.com (M.H.); bahsis.lahoucine@gmail.com (L.B.);

Received: 11.09.2021; Revised: 10.11.2021; Accepted: 14.11.2021; Published: 27.11.2021

\begin{abstract}
: 1,2,3-triazole skeleton is a privileged building block for the discovery of new promising anticancer agents. In this report, new 1,4-disubstituted 1,2,3-triazoles with the bioisoster triazole moiety were straightforwardly prepared under copper-catalyzed azide-alkyne [3+2] cycloaddition reactions (CuAAC) regime using a variety of both functional organic azides and terminal alkynes. The resulting functional 1,4-disubstituted 1,2,3-triazole compounds were fully characterized and subsequently tested for their antiproliferative activity against four different cancer cell lines. The cytotoxicity tests carried out with these 1,2,3-triazole derivatives show average $\mathrm{IC}_{50}$ values ranging from 15 to $50 \mu \mathrm{M}$ by comparison with the standard reference drug, namely doxorubicin. The phosphonate 1,2,3-triazole derivative was found to exhibit the best antiproliferative activity among the studied compounds against the HT-1080 cell lines. It was chosen to evaluate its mode of action in these cancer cell lines. The cell cycle study showed that the phosphonate derivative, compound 8 , is the most active inhibitor of the cell cycle at the G0/G1 phase, inducing apoptosis independently of Caspase-3 and causing an increase in the mitochondrial membrane potential $(\Delta \Psi \mathrm{m})$ in the HT-1080 cell lines. Molecular docking studies of this phosphonate derivative into the MMP-2 and MMP-9 metalloproteinases receptors demonstrated the relevance of triazole scaffolds and the pendant phosphonate group in establishing $\pi$-anion, $\pi$-alkyl and hydrogen bonding type interactions with residual components in the active MMP pocket.
\end{abstract}

Keywords: click chemistry; 1,2,3-triazole; phosphonate; anticancer; molecular docking.

(C) 2021 by the authors. This article is an open-access article distributed under the terms and conditions of the Creative Commons Attribution (CC BY) license (https://creativecommons.org/licenses/by/4.0/).

\section{Introduction}

Cancer is considered the most common cause of human deaths worldwide due to the uncontrolled growth of abnormal cells [1], responsible for almost 9.6 million deaths in 2018 [2]. In this respect, the World Health Organization has declared that cancer diseases cause about 1 in over 6 deaths worldwide. In recent decades, great advancements have been made in 
the search for chemotherapeutics as anticancer agents, but unfortunately, these chemical agents are still causing serious health problems such as organ damage, hair and weight loss, as well as side effects that include off-target toxicity and drug resistance with receptors $[3,4]$. Global spending on cancer medicines continues to rise tremendously with therapeutic and supportive care [5]. Consequently, the discovery of new cancer drugs based on the description of the properties of cancer cells for the achievement of stronger inhibitory effectiveness without disturbing normal cells urges the need to explore new drugs with low side effects and high efficiency [6].

1,2,3-Triazole is one of the most important classes of nitrogen-rich heterocyclic scaffolds, which can be regioselectively prepared by copper-catalyzed azide-alkyne cycloaddition reactions (CuAAC) under click chemistry regime through [7]. This heterocycle compound class is considered amide bioisostere that could form diverse non-covalent interactions, such as van der Waals forces and hydrogen bonds with various proteins, enzymes, and receptors with high resistance to enzymatic degradation, which enables their potential use in medicinal chemistry [8]. For example, 1,2,3-triazoles-containing carboxyamidotriazole (see Figure 1) has been proven to be a potential anticancer agent via the cell cycle arrest of cancer cells. This study suggests that 1,2,3-triazole moiety may improve anti lung cancer drug effects with low toxicity and high efficiency [9].

Many heterocyclic compounds containing 1,4-disubstituted 1,2,3-triazole derivatives have increasingly used as biologically active drugs, such as anti-malarial [10,11], -microbial [12,13], -tubercular [14], -epileptic [15], -viral [16], -inflammatory [17], -HIV [18], -diabetic $[19,20]$, -oxidant [21], and -allergic ones [22]. Actually, the 1,2,3-triazole core is an excellent building block in the discovery of potent anticancer agents, some of them such as Cefatrizine, and 1,2,3-triazole-dithiocarbamate (see Figure 1) were already utilized as anticancer agent against human cell lines such as colon, lung, prostate, and breast cancers [23,24].
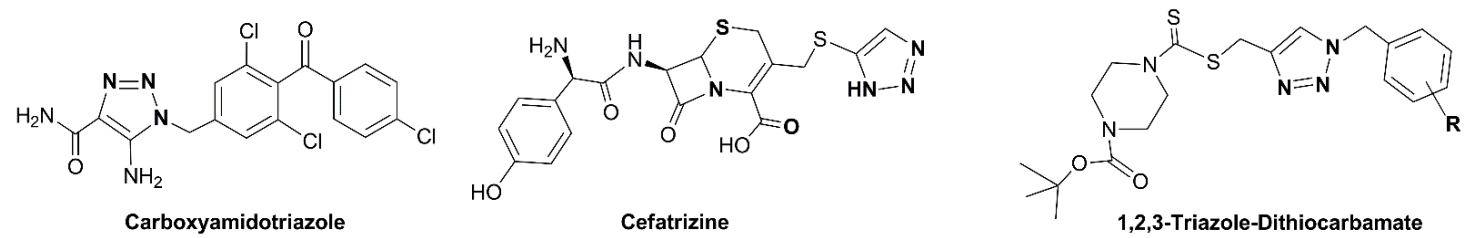

Figure 1. Some of the biologically active 1,2,3-triazole-containing drugs.

In the framework of our efforts for the development of new functional 1,2,3-triazole compounds with anticancer potential and particularly 1,2,3-triazole-containing hybrids that possess anticancer pharmacophore moieties on the triazole core, we carried out the synthesis of a variety of functional 1,4-disubstituted 1,2,3-triazole-based anticancer pharmacophores, with sterically demanding or electron-withdrawing/donating groups at 1,4-positions on triazole moiety, via copper-catalyzed azide-alkyne [3+2] cycloaddition reaction by using a variety of functional organic azides and terminal alkynes.

The molecular structures of the newly prepared 1,2,3-triazoles were investigated using ${ }^{1} \mathrm{H}$ NMR, ${ }^{13} \mathrm{C}$ NMR, FTIR spectroscopies, and HRMS analysis. The evaluation of the cytotoxic effect and the antiproliferative activity of the subject compounds, including newly prepared and other reported 1,2,3-triazoles, on various human cancers, such as those of lung (A-549), fibrosarcoma (HT-1080), and breast (MCF-7 and MDA-MB-231), were conducted.

Molecular docking calculations were performed to explain the biological activity of the most active compound at the molecular level by using the active metalloproteinase receptors 
of the cancer cells. The ProtoMol is a Molecular Dynamics Framework that optimizes the interactions of ligands into the receptor pocket in order to predict all binding modes. ProtoMol is generally established by three methods: (i) the automatic one that relies on figuring out the largest cavity in the protein; (ii) the coordinate space of ligand as the receptor; (iii) the residues specifying the protein $[25,26]$. In the present study, automatic docking was applied.

\section{Materials and Methods}

\subsection{Chemicals and techniques.}

The reagents were purchased from Aldrich and Across. The melting points (MP) of the prepared products were determined by the Kofler bench. High-resolution mass spectrometry (HRMS) was carried out on a Q-TOF micro mass spectrometer. ${ }^{1} \mathrm{H}$ and ${ }^{13} \mathrm{C}$ NMR analyses were investigated in $\mathrm{CDCl}_{3}$ with a $300 \mathrm{MHz}$ Bruker Avance III spectrometer. Chemical shifts $(\delta)$ are expressed in ppm, and coupling constants $(J)$ are given in Hz. They were recorded relative to the solvent $\mathrm{CDCl}_{3}$ signal $\left(7.26\right.$ and $77.1 \mathrm{ppm}$ for ${ }^{1} \mathrm{H} \mathrm{NMR}$ and ${ }^{13} \mathrm{C} \mathrm{NMR}$, respectively). FTIR spectra were carried out on a Thermo Nicolet FTIR Nexus spectrophotometer using $\mathrm{KBr}$ pellets.

\subsubsection{Synthesis of 1,2,3-triazoles (1-10).}

Compounds 7-10 were synthesized according to the previously reported method 2729].

\subsubsection{General procedure for the preparation of 1-4.}

One equivalent of the alkyne $(1 \mathrm{mmol})$ and 1.2 equivalent of azide $(1.2 \mathrm{mmol})$ were placed in a vial equipped with a magnetic stirrer; then $1 \mathrm{~mol} \%$ of $\mathrm{CuSO}_{4} \cdot 5 \mathrm{H}_{2} \mathrm{O} 5 \mathrm{~mol} \%$ of sodium ascorbate were added together with $5 \mathrm{~mL}$ of water. The mixture was allowed to react under continuous stirring at room temperature for eight hours while TLC monitored the reaction. After removing the copper species by simple filtration, the reaction product was extracted three times using $\mathrm{CH}_{2} \mathrm{Cl}_{2}$, and each organic phase was dried over $\mathrm{Na}_{2} \mathrm{SO}_{4}$. After filtration, $\mathrm{CH}_{2} \mathrm{Cl}_{2}$ was evaporated under reduced pressure, affording the corresponding 1,2,3triazole compound, purified by recrystallization using hexane/ethyl acetate mixtures, if needed.

\subsubsection{General procedure for the preparation of 5 and 6.}

One equivalent of styrene oxide $(1 \mathrm{mmol})$, one equivalent of the alkyne $(1 \mathrm{mmol})$ was introduced into a $25 \mathrm{~mL}$ round-bottom flask containing $10 \mathrm{~mL}$ of water; then sodium azide (72 $\mathrm{mg}, 1.1 \mathrm{mmol})$ was added, followed by $\mathrm{Cu}(\mathrm{OAc})_{2} \cdot \mathrm{H}_{2} \mathrm{O}(5 \mathrm{~mol} \%)$. The reaction mixture was heated to $60{ }^{\circ} \mathrm{C}$ and monitored by TLC until complete reaction. Once the reaction was completed, the mixture was diluted with water, and the product was extracted with ethyl acetate $(4 \times 10 \mathrm{~mL})$. The organic phases were combined and dried over $\mathrm{Na}_{2} \mathrm{SO}_{4}$, and the solvent was removed under reduced pressure to yield the desired 1,4-disubstituted 1,2,3-triazole derivative, which was purified by recrystallization in hexane/ethyl acetate mixed solvent if needed. The prepared compounds were characterized by NMR, FI-IR and HRMS analyses (see supplementary materials Figures S1-S30).

Caution! Sodium azide is a highly toxic chemical and should be handled with extreme care. 
2.1.2. Characterization of 1-6.

\subsubsection{4-Phenyl-1-(p-tolyl)-1H-1,2,3-triazole (1).}

Yield: $91 \%$; white solid. $R_{F}=0.61$ (hexane/ethyl acetate $(2: 1 \mathrm{v} / \mathrm{v}) . \mathrm{MP} 172-174{ }^{\circ} \mathrm{C}$ (Lit. [30] MP 169-171 $\left.{ }^{\circ} \mathrm{C}\right)$. FTIR ( $\left.\mathrm{KBr}, v / \mathrm{cm}^{-1}\right): 3419$ (O-H stretch, water); 3050 (C-H stretching, $\mathrm{sp}^{2}$ ); 2916, 2855 and 1453 (C-H stretch, $\left.\mathrm{sp}^{3}\right) ; 1610$ (C=C stretch); 1520 (C-C stretch, aromatic); 1232 and 1032 (C-N stretch). ${ }^{1} \mathrm{H}$ NMR: $\delta(\mathrm{ppm}): 2.46$ (s, 3H, $\left.\mathrm{CH}_{3}\right), 7.36$ (d, $2 \mathrm{H}, J=8.1 \mathrm{~Hz}$, $\mathrm{CH}_{\mathrm{ar}}$ ), 7.40 (t, $\left.1 \mathrm{H}, J=7.3 \mathrm{~Hz}, \mathrm{CH}_{\mathrm{ar}}\right), 7.49$ (t, 2H, $\left.J=7.3 \mathrm{~Hz}, \mathrm{CH}_{\mathrm{ar}}\right), 7.69$ (d, 2H, $J=8.4 \mathrm{~Hz}$, $\left.\mathrm{CH}_{\mathrm{ar}}\right), 7.94$ (d, $\left.2 \mathrm{H}, J=7.1 \mathrm{~Hz}, \mathrm{CH}_{\mathrm{ar}}\right), 8.19$ (s, 1H, $\left.\mathrm{CH}_{\text {triazole }}\right) .{ }^{13} \mathrm{C} \mathrm{NMR}: \delta(\mathrm{ppm}): 21.1\left(\mathrm{CH}_{3}\right)$, 112.7 ( $\left.\mathrm{HC}_{\mathrm{ar}}\right), 120.4\left(2 \mathrm{HC}_{\mathrm{ar}}\right), 125.8\left(2 \mathrm{HC}_{\mathrm{ar}}\right), 128.9$ ( $\left.\mathrm{HC}_{\text {triazole }}\right), 128.4\left(2 \mathrm{HC}_{\mathrm{ar}}\right), 130.3\left(2 \mathrm{HC}_{\mathrm{ar}}\right)$, $134.8\left(\mathrm{C}_{\mathrm{ar}}\right), 138.9\left(\mathrm{C}_{\mathrm{ar}}\right), 153.1\left(\mathrm{C}_{\mathrm{ar}}\right), 153.1\left(\mathrm{C}_{\mathrm{ar}}\right)$. HRMS: $m / z[\mathrm{M}+\mathrm{H}]^{+}$Calcd. For $\mathrm{C}_{15} \mathrm{H}_{14} \mathrm{~N}_{3}$ : 236.1182 Found: 236.1175.

\subsubsection{1-(4-Methoxyphenyl)-4-phenyl-1H-1,2,3-triazole (2).}

Yield: $89 \%$; white solid. $R_{F}=0.53$ (hexane/ethyl acetate $(2: 1 \mathrm{v} / \mathrm{v})$. MP $171-173{ }^{\circ} \mathrm{C}$ (Lit. [30] MP 162-164 $\left.{ }^{\circ} \mathrm{C}\right)$. FTIR ( $\left.\mathrm{KBr}, v / \mathrm{cm}^{-1}\right): 3411$ (O-H stretch, water); 3119 (C-H stretching, $\left.\mathrm{sp}^{2}\right) ; 2953,2839$ (C-H stretch, $\left.\mathrm{sp}^{3}\right) ; 1655$ (C=C stretch); 1242-1106 (C-N stretch); 1038 (C-O stretch); 828 (=C-H stretch). ${ }^{1} \mathrm{H}$ NMR: $\delta(\mathrm{ppm}): 3.91\left(\mathrm{~s}, 3 \mathrm{H}, \mathrm{CH}_{3}\right), 7.07(\mathrm{~d}, 2 \mathrm{H}, J=9.0 \mathrm{~Hz}$, $\left.\mathrm{CH}_{\mathrm{ar}}\right), 7.38$ (t, 1H, J = 7.4 Hz, $\left.\mathrm{CH}_{\mathrm{ar}}\right), 7.49$ (t, $\left.2 \mathrm{H}, J=7.0 \mathrm{~Hz}, \mathrm{CH}_{\mathrm{ar}}\right), 7.72(\mathrm{~d}, 2 \mathrm{H}, J=9.0 \mathrm{~Hz}$, $\left.\mathrm{CH}_{\mathrm{ar}}\right), 7.95\left(\mathrm{~d}, 2 \mathrm{H}, J=6.8 \mathrm{~Hz}, \mathrm{CH}_{\mathrm{ar}}\right), 8.20\left(\mathrm{~s}, 1 \mathrm{H}, \mathrm{CH}_{\text {triazole }}\right) .{ }^{13} \mathrm{C} \mathrm{NMR:} \delta(\mathrm{ppm}): 55.6\left(\mathrm{CH}_{3}\right)$, $114.8\left(2 \mathrm{HC}_{\mathrm{ar}}\right), 122.2\left(2 \mathrm{HC}_{\mathrm{ar}}\right), 125.8\left(2 \mathrm{HC}_{\mathrm{ar}}\right), 128.3\left(\mathrm{HC}_{\mathrm{ar}}\right), 128.9\left(3 \mathrm{HC}_{\mathrm{ar}}\right), 131.3\left(\mathrm{C}_{\mathrm{ar}}\right), 134.8$ $\left(\mathrm{C}_{\mathrm{ar}}\right), 138.9\left(\mathrm{C}_{\mathrm{ar}}\right), 159.8$ (HC triazole $)$. HRMS: $m / z[\mathrm{M}+\mathrm{H}]^{+}$Calcd. for $\mathrm{C}_{15} \mathrm{H}_{14} \mathrm{~N}_{3} \mathrm{O}: 252.1131$ Found: 252.1122.

\subsubsection{1-(4-Methoxyphenyl)-4-phenylsulfanylmethyl-1H-1,2,3-triazole (3).}

Yield: 92\%; white solid. $R_{F}=0.39$ (hexane/ethyl acetate $(2: 1 \mathrm{v} / \mathrm{v}) . \mathrm{MP} 100-102{ }^{\circ} \mathrm{C}$. FTIR (KBr, v/ $\left.\mathrm{cm}^{-1}\right)$ : 3417 (O-H stretch, water); 3130-3077 (C-H stretch, sp $\left.{ }^{2}\right)$; 3007, 2833, 1470-1442 $\mathrm{cm}^{-1}\left(\mathrm{CH}_{3}\right.$ stretch); 1514 (C=C stretch); 1246 (C-N stretch); 1038 (C-O stretch). ${ }^{1} \mathrm{H}$ NMR: $\delta(\mathrm{ppm}): 3.88\left(\mathrm{~s}, 3 \mathrm{H}, \mathrm{CH}_{3}\right), 4.34\left(\mathrm{~s}, 2 \mathrm{H}, \mathrm{CH}_{2}\right), 7.02\left(\mathrm{~d}, 2 \mathrm{H}, J=8.8 \mathrm{~Hz}, \mathrm{CH}_{\mathrm{ar}}\right), 7.22(\mathrm{t}$, $\left.2 \mathrm{H}, J=7.1 \mathrm{~Hz}, \mathrm{CH}_{\mathrm{ar}}\right), 7.30\left(\mathrm{t}, J=7.8 \mathrm{~Hz}, 1 \mathrm{H}, \mathrm{CH}_{\mathrm{ar}}\right), 7.41\left(\mathrm{~d}, 2 \mathrm{H}, J=7.5 \mathrm{~Hz}, \mathrm{CH}_{\mathrm{ar}}\right), 7.59$ (d, $\left.2 \mathrm{H}, J=8.8 \mathrm{~Hz}, \mathrm{CH}_{\mathrm{ar}}\right), 7.68\left(\mathrm{~s}, 1 \mathrm{H}, \mathrm{CH}_{\text {triazole }}\right) .{ }^{13} \mathrm{CNMR}: \delta(\mathrm{ppm}): 28.9\left(\mathrm{CH}_{2}\right), 55.6\left(\mathrm{CH}_{3}\right), 114.7$ $\left(2 \mathrm{HC}_{\mathrm{ar}}\right), 122.2\left(2 \mathrm{HC}_{\mathrm{ar}}\right), 126.6(\mathrm{HC}), 129.1\left(2 \mathrm{HC}_{\mathrm{ar}}\right), 129.6\left(2 \mathrm{HC}_{\mathrm{ar}}\right), 132.1\left(\mathrm{HC}_{\text {triazole }}\right), 135.1$ $\left(\mathrm{C}_{\mathrm{ar}}\right), 135.4\left(\mathrm{C}_{\mathrm{ar}}\right), 151.5\left(\mathrm{C}_{\mathrm{ar}}\right), 159.8\left(\mathrm{C}_{\mathrm{ar}}\right)$. HRMS: $m / z[\mathrm{M}+\mathrm{H}]^{+}$. Calcd. for $\mathrm{C}_{16} \mathrm{H}_{16} \mathrm{~N}_{3} \mathrm{OS}$ : 298.1008 Found: 298.0998.

\subsubsection{4-Phenylsulfanylmethyl-1-p-tolyl-1H-1,2,3-triazole (4).}

Yield: 95\%; yellow solid. $R_{F}=0.50$ (hexane/ethyl acetate $(2: 1 \mathrm{v} / \mathrm{v})$. MP 93-95 ${ }^{\circ} \mathrm{C}$. FTIR $\left(\mathrm{KBr}, v / \mathrm{cm}^{-1}\right): 3421$ (O-H stretch, water); 3052, 1627-1582, 733 (C-H stretch, $\left.\mathrm{sp}^{2}\right)$; 1475-1435 $\left(\mathrm{CH}_{3}\right.$ stretch); 1518 (C=C, stretch); 1225-1039 (C-N stretch). ${ }^{1} \mathrm{H}$ NMR: $\delta$ (ppm): 2.34 (s, 3H, $\left.\mathrm{CH}_{3}\right), 4.24$ (s, $\left.2 \mathrm{H}, \mathrm{CH}_{2}\right), 7.00-7.17$ (m, 2H, $\mathrm{HC}_{\mathrm{ar}}$ ), 7.18-7.25 (m, 3H, $\left.\mathrm{HC}_{\mathrm{ar}}\right), 7.27-7.34(\mathrm{~m}, 2 \mathrm{H}$, $\mathrm{HC}_{\mathrm{ar}}$ ), 7.43-7.50 (m, 2H, HC $\left.\mathrm{ar}\right), 7.66$ (s, 1H, HC triazole). ${ }^{13} \mathrm{C} \mathrm{NMR:} \delta(\mathrm{ppm}): 21.1\left(\mathrm{CH}_{3}\right), 28.9$ $\left(\mathrm{CH}_{2}\right), 120.4$ (2 $\left.\mathrm{HC}_{\mathrm{ar}}\right), 126.6\left(2 \mathrm{HC}_{\mathrm{ar}}\right), 129.1\left(\mathrm{HC}_{\mathrm{ar}}\right), 129.6\left(2 \mathrm{HC}_{\mathrm{ar}}\right), 130.2\left(\mathrm{HC}_{\mathrm{ar}}\right), 132.1$ $\left(\mathrm{HC}_{\text {triazole }}\right), 134.7\left(\mathrm{C}_{\mathrm{ar}}\right), 135.4\left(\mathrm{C}_{\mathrm{ar}}\right), 138.9\left(\mathrm{C}_{\mathrm{ar}}\right), 145.1\left(\mathrm{C}_{\mathrm{ar}}\right) . \mathrm{HRMS}: m / z[\mathrm{M}+\mathrm{H}]^{+} \mathrm{Calcd}$. for $\mathrm{C}_{16} \mathrm{H}_{16} \mathrm{~N}_{3} \mathrm{~S}$ : 282.1059 found: 282.1049. 


\subsubsection{2-Phenyl-2-(4-phenyl-1H-1,2,3-triazol-1-yl)ethan-1-ol (5).}

Yield: 92\%; white solid. $R_{F}=0.54$ (hexane/ethyl acetate $(2: 1 \mathrm{v} / \mathrm{v}) . \mathrm{MP} 119-120^{\circ} \mathrm{C}$ (Lit. [31] MP 125-127 $\left.{ }^{\circ} \mathrm{C}\right)$. FTIR (KBr, v/cm $\left.{ }^{-1}\right): 3383$ (O-H stretch); 3094-2925 (C-H stretch, sp ${ }^{2}$ ); 1607-1459, 756 (C=C, =C-H stretch); 1065 (C-O stretch); 1214 (C-N stretch). ${ }^{1} \mathrm{H}$ NMR: $\delta$ (ppm): $4.16\left(\mathrm{dd}, 1 \mathrm{H}, J=12.4,3.7 \mathrm{~Hz}, \mathrm{CH}_{2}\right), 4.57\left(\mathrm{dd}, 1 \mathrm{H}, J=12.4,8.2 \mathrm{~Hz}, \mathrm{CH}_{2}\right), 5.61(\mathrm{dd}$, $1 \mathrm{H}, J=8.2,3.7 \mathrm{~Hz}, \mathrm{CH}), 7.18-7.20\left(\mathrm{~m}, 3 \mathrm{H}, \mathrm{CH}_{\mathrm{ar}}\right), 7.26-7.29\left(\mathrm{~m}, 2 \mathrm{H}, \mathrm{CH}_{\mathrm{ar}}\right), 7.31-7.37(\mathrm{~m}, 3 \mathrm{H}$, $\left.\mathrm{CH}_{\mathrm{ar}}\right)$, 7.71-7.74 (m, 2H, $\left.\mathrm{CH}_{\mathrm{ar}}\right), 7.63\left(\mathrm{~s}, 1 \mathrm{H}, \mathrm{CH}_{\text {triazole }}\right) .{ }^{13} \mathrm{C} \mathrm{NMR}: \delta(\mathrm{ppm}): 65.3\left(\mathrm{CH}_{2}\right), 67.3$ $(\mathrm{CH}), 125.7\left(\mathrm{HC}_{\mathrm{ar}}\right), 127.1\left(\mathrm{HC}_{\mathrm{ar}}\right), 128.3$ ( $\left.\mathrm{HC}_{\mathrm{ar}}\right), 128.9$ ( $\left.\mathrm{HC}_{\text {triazole }}\right), 129.1\left(\mathrm{HC}_{\mathrm{ar}}\right), 129.2\left(\mathrm{HC}_{\mathrm{ar}}\right)$, $130.2\left(\mathrm{HC}_{\mathrm{ar}}\right), 136.0\left(\mathrm{C}_{\mathrm{ar}}\right), 141.2\left(\mathrm{C}_{\mathrm{ar}}\right), 148.1\left(\mathrm{C}_{\mathrm{ar}}\right)$. HRMS: $m / z$ [M+H] ${ }^{+}$Calcd. for $\mathrm{C}_{16} \mathrm{H}_{16} \mathrm{~N}_{3} \mathrm{O}$ : 266.1288 Found: 266.1295.

\subsubsection{2-(4-(Phenoxymethyl)-1H-1,2,3-triazol-1-yl)-2-phenylethan-1-ol (6).}

Yield: 90\%; yellow solid. $R_{F}=0.51$ (hexane/ethyl acetate $(2: 1 \mathrm{v} / \mathrm{v}) . \mathrm{MP} 90-92{ }^{\circ} \mathrm{C}$. FTIR $\left(\mathrm{KBr}, \mathrm{v} / \mathrm{cm}^{-1}\right)$ : $3415\left(\mathrm{O}-\mathrm{H}\right.$ stretch); 3094-2872 (C-H stretch, $\left.\mathrm{sp}^{2}\right) ; 1593,853,(\mathrm{C}=\mathrm{C},=\mathrm{C}-\mathrm{H}$ stretch); 1234 (C-N stretch); 1060 (C-O stretch). ${ }^{1} \mathrm{H}$ NMR: $\delta$ (ppm): 3.46 (s, 1H, OH), 4.22 (d, $\left.1 \mathrm{H}, J=10.9 \mathrm{~Hz}, \mathrm{CH}_{2}\right), 4.61(\mathrm{dd}, 1 \mathrm{H}, J=12 \mathrm{~Hz}, J=8.5 \mathrm{~Hz}, \mathrm{CH}), 5.20\left(\mathrm{~s}, 1 \mathrm{H}, \mathrm{CH}_{2}\right), 5.68(\mathrm{~d}$, $\left.1 \mathrm{H}, J=10.9 \mathrm{~Hz}, \mathrm{CH}_{2}\right), 6.99\left(\mathrm{~d}, 2 \mathrm{H}, J=7.8 \mathrm{~Hz}, \mathrm{CH}_{\mathrm{ar}}\right), 7.05-7.25\left(\mathrm{~m}, 5 \mathrm{H}, \mathrm{CH}_{\mathrm{ar}}\right), 7.26(\mathrm{~d}, 2 \mathrm{H}, J$ $\left.=3.7 \mathrm{~Hz}, \mathrm{CH}_{\mathrm{ar}}\right), 7.32\left(\mathrm{t}, 1 \mathrm{H}, J=7.8 \mathrm{~Hz}, \mathrm{CH}_{\mathrm{ar}}\right), 7.67$ (s, $\left.1 \mathrm{H}, \mathrm{CH}_{\text {triazole }}\right) .{ }^{13} \mathrm{C} \mathrm{NMR:} \delta(\mathrm{ppm}): 61.9$ $\left(\mathrm{CH}_{2}\right), 65.0\left(\mathrm{CH}_{2}\right), 67.4(\mathrm{CH}), 114.2\left(2 \mathrm{HC}_{\mathrm{ar}}\right), 121.3\left(\mathrm{HC}_{\mathrm{ar}}\right), 126.8\left(\mathrm{HC}_{\text {triazole }}\right), 127.1\left(\mathrm{HC}_{\mathrm{ar}}\right)$, 129.2 (2 $\left.\mathrm{HC}_{\mathrm{ar}}\right), 129.6\left(2 \mathrm{HC}_{\mathrm{ar}}\right), 135.9\left(\mathrm{C}_{\mathrm{ar}}\right), 157.4\left(\mathrm{C}_{\mathrm{ar}}\right), 158.2\left(\mathrm{C}_{\mathrm{ar}}\right)$. HRMS: $m / z[\mathrm{M}+\mathrm{H}]^{+} \mathrm{Calcd}$. for $\mathrm{C}_{17} \mathrm{H}_{18} \mathrm{~N}_{3} \mathrm{O}_{2}$ : 296.1393 Found: 296.1387.

2.1.2.7. 3-(4-(4-Dimethylaminophenyl)-1H-1,2,3-triazol-1-yl)-propylphosphonic acid diethyl ester (7).

Yield: $88 \%$; brown oil. $R_{F}=0.6$ (hexane/ethyl acetate $(1: 6 \mathrm{v} / \mathrm{v})$. FTIR $\left(\mathrm{KBr}, \mathrm{v} / \mathrm{cm}^{-1}\right)$ : $3448 \mathrm{~cm}^{-1}$ (O-H stretch, water); 3122 (C-H stretch, sp $\left.)^{2}\right)$ 1507-1450 (C=C stretch); 818 (=C-H stretch). ${ }^{1} \mathrm{H}$ NMR: $\delta$ (ppm): 1.21-1.27 (t, $\left.J=7.2 \mathrm{~Hz}, 6 \mathrm{H}, 2 \mathrm{CH}_{3}\right), 1.64-1.75\left(\mathrm{~m}, 2 \mathrm{H}, \mathrm{CH}_{2}\right)$, 2.16-2.26 (m, $\left.2 \mathrm{H}, 2 \mathrm{CH}_{2}\right), 3.03\left(\mathrm{~s}, 6 \mathrm{H}, 2 \mathrm{CH}_{3}\right), 3.99-4.16\left(\mathrm{~m}, 4 \mathrm{H}, 2 \mathrm{CH}_{2}\right), 4.42-4.47(\mathrm{t}, J=6.6$ $\left.\mathrm{Hz}, 2 \mathrm{H}, \mathrm{CH}_{2}\right), 7.24-7.38$ (s, $\left.2 \mathrm{H}, 2 \mathrm{CH}_{\mathrm{ar}}\right), 7.74$ (s, $\left.1 \mathrm{H}, \mathrm{CH}\right), 7.77-7.78$ (s, $\left.2 \mathrm{H}, 2 \mathrm{CH}_{\mathrm{ar}}\right) .{ }^{13} \mathrm{C}$ NMR: $\delta$ (ppm): 16.4-16.4 $\left(2 \mathrm{CH}_{3}\right), 20.8\left(2 \mathrm{CH}_{3}\right), 23.4-23.7\left(\mathrm{CH}_{2}\right), 21.5\left(\mathrm{CH}_{2}\right), 49.9-50.1$ $\left(\mathrm{CH}_{2}\right), 61.9-62.0\left(2 \mathrm{CH}_{2}\right), 120.0\left(\mathrm{C}_{\mathrm{ar}}\right), 125.7-128.8$ (4 $\left.\mathrm{HC}_{\mathrm{ar}}\right), 130.4\left(\mathrm{HC}_{\text {triazole }}\right), 144.7\left(\mathrm{C}_{\text {triazole }}\right)$, $147.8\left(\mathrm{C}_{\mathrm{ar}}\right)$. HRMS (ESI) $[\mathrm{M}+\mathrm{H}]^{+}$found $\mathrm{m} / z$ : Calcd for $\mathrm{C}_{17} \mathrm{H}_{28} \mathrm{~N}_{4} \mathrm{O}_{3} \mathrm{P}$ : 367.1894. Found 367.1897 .

\subsubsection{8. (3-(4-Phenyl-1H-1,2,3-triazol-1-yl)-propyl)phosphonic acid diethyl ester (8).}

Yield: $86 \%$, brown oil. $R_{F}=0.71$ (hexane/ethyl acetate $(1: 6 \mathrm{v} / \mathrm{v})$. FTIR $\left(\mathrm{KBr}, \mathrm{v} / \mathrm{cm}^{-1}\right)$ : $3449 \mathrm{~cm}^{-1}\left(\mathrm{O}-\mathrm{H}\right.$ stretch, water); $3132\left(\mathrm{C}-\mathrm{H}\right.$ stretch, sp $\left.{ }^{2}\right) ; 1456(\mathrm{C}=\mathrm{C}$ stretch$) ; 771$ (=C-H stretch); 2980 (C-H stretching, sp $\left.{ }^{3}\right) ; 1384\left(\mathrm{CH}_{3}\right.$ stretch); 1233 (C-N stretch); 1023 (C-O stretch). ${ }^{1} \mathrm{H}$ NMR: $\delta$ (ppm): $1.24\left(\mathrm{t}, J=7.2 \mathrm{~Hz}, 6 \mathrm{H}, 2 \mathrm{CH}_{3}\right), 1.64-1.75\left(\mathrm{~m}, 2 \mathrm{H}, \mathrm{CH}_{2}\right), 2.16-$ $2.26\left(\mathrm{~m}, 2 \mathrm{H}, \mathrm{CH}_{2}\right), 4.00-4.06\left(\mathrm{~m}, 4 \mathrm{H}, 2 \mathrm{CH}_{2}\right), 4.44\left(\mathrm{t}, J=6.6 \mathrm{~Hz}, 2 \mathrm{H}, \mathrm{CH}_{2}\right), 7.20-2.38$ (s, 3 $\left.\mathrm{H}, 3 \mathrm{CH}_{\mathrm{ar}}\right), 7.74(\mathrm{~s}, 1 \mathrm{H}, \mathrm{CH}), 7.76-7.77\left(\mathrm{~s}, 2 \mathrm{H}, 2 \mathrm{CH}_{\mathrm{ar}}\right) .{ }^{13} \mathrm{C} \mathrm{NMR}: \delta(\mathrm{ppm}): 16.4-16.4\left(2 \mathrm{CH}_{3}\right)$, $21.5\left(\mathrm{CH}_{2}\right), 23.4-23.6\left(2 \mathrm{CH}_{2}\right), 49.8-50.1\left(\mathrm{CH}_{2}\right), 61.9-62.0\left(\mathrm{CH}_{2}\right), 119.0\left(\mathrm{C}_{\mathrm{ar}}\right), 125.7-128.8(4$ $\left.\mathrm{HC}_{\mathrm{ar}}\right), 130.5\left(\mathrm{HC}_{\text {triazole }}\right), 147.8\left(\mathrm{C}_{\mathrm{ar}}\right), 173.9\left(\mathrm{C}_{\text {triazole }}\right), \mathrm{HRMS}(\mathrm{ESI})[\mathrm{M}+\mathrm{H}]^{+}$found $m / z$ : Calcd for $\mathrm{C}_{15} \mathrm{H}_{23} \mathrm{~N}_{3} \mathrm{O}_{3} \mathrm{P}: 324.1472$. Found: 324.1477 . 


\subsubsection{9. (1-Benzyl-1H-1,2,3-triazol-4-yl) methyl benzoate (9).}

Yield: $97 \%$, white solid. $R_{F}=0.23$ (hexane/ethyl acetate $(3: 1 \mathrm{v} / \mathrm{v})$. MP $122.5^{\circ} \mathrm{C}$ (Lit. [32] mp 122-123 ${ }^{\circ} \mathrm{C}$ ). FTIR ( $\left.\mathrm{KBr}, v / \mathrm{cm}^{-1}\right): 3443 \mathrm{~cm}^{-1}$ (O-H stretch, water); 3132 (C-H stretch, $\left.\mathrm{sp}^{2}\right) ; 2980\left(\mathrm{C}-\mathrm{H}\right.$ stretching, sp $\left.{ }^{3}\right) ; 1597(\mathrm{C}=\mathrm{O}$ stretch$) ; 1486(\mathrm{C}=\mathrm{C}$ stretch$) ; 1239$ (C-N stretch); 1120 (C-O stretch). ${ }^{1} \mathrm{H}$ NMR: $\delta$ (ppm): 5.47 (s, 2H, $\left.\mathrm{CH}_{2}\right) ; 5.54$ (s, 2H, $\left.\mathrm{CH}_{2}\right) ; 7.28-7.38$ (m, 5H, $\left.\mathrm{CH}_{\mathrm{ar}}\right) ; 7.40\left(\mathrm{~s}, 1 \mathrm{H}, \mathrm{CH}_{\mathrm{ar}}\right) ; 7.43\left(\mathrm{~s}, 1 \mathrm{H}, \mathrm{CH}_{\mathrm{ar}}\right) ; 7.46\left(\mathrm{~s}, 1 \mathrm{H}, \mathrm{CH}_{\text {triazole }}\right) ; 7.57$ (s, 1H, $\left.\mathrm{CH}_{\mathrm{ar}}\right) ; 8.03-$ $8.05\left(\mathrm{~d}, 2 \mathrm{H}, \mathrm{CH}_{\mathrm{ar}}\right) \cdot{ }^{13} \mathrm{C}$ NMR: $\delta(\mathrm{ppm}): 54.8\left(\mathrm{CH}_{2}\right) ; 58.4\left(\mathrm{CH}_{2}\right) ; 128.6\left(\mathrm{CH}_{\text {triazole }}\right) ; 128.7(2$ $\left.\mathrm{CH}_{\mathrm{ar}}\right) ; 129.3\left(2 \mathrm{CH}_{\mathrm{ar}}\right) ; 129.6\left(2 \mathrm{CH}_{\mathrm{ar}}\right) ; 130.1\left(4 \mathrm{CH}_{\mathrm{ar}}\right) ; 133.6\left(\mathrm{C}_{\mathrm{ar}}\right) ; 134.7\left(\mathrm{C}_{\text {triazole }}\right) ; 153.2\left(\mathrm{C}_{\mathrm{ar}}\right)$; $166.8\left(\mathrm{C}_{\text {carbonyl }}\right)$. HRMS (ESI) $[\mathrm{M}+\mathrm{H}]{ }^{+}$found $m / z$ : Calcd for $\mathrm{C}_{17} \mathrm{H}_{16} \mathrm{~N}_{3} \mathrm{O}_{2}=294.1237$. Found: 294.1241.

\subsubsection{0. (1-(4-Fluorobenzyl)-1H-1,2,3-triazol-4-yl) methyl benzoate (10).}

Yield: $95 \%$, White solid. $R_{F}=0.13$ (hexane/ethyl acetate $(3: 1 \mathrm{v} / \mathrm{v})$. MP $149-150^{\circ} \mathrm{C}$. FTIR $\left(\mathrm{KBr}, v / \mathrm{cm}^{-1}\right): 3419 \mathrm{~cm}^{-1}(\mathrm{O}-\mathrm{H}$ stretch, water $) ; 3141\left(\mathrm{C}-\mathrm{H}\right.$ stretch, sp $\left.{ }^{2}\right) ; 3077(\mathrm{C}-\mathrm{H}$ stretching, $\left.\mathrm{sp}^{3}\right) ; 1708(\mathrm{C}=\mathrm{O}$ stretch); $1501(\mathrm{C}=\mathrm{C}$ stretch$) ; 1271$ (C-N stretch); 1095 (C-O stretch). ${ }^{1} \mathrm{H}$ NMR: $\delta$ (ppm): $5.46\left(\mathrm{~s}, 2 \mathrm{H}, \mathrm{CH}_{2}\right) ; 5.51\left(\mathrm{~s}, 2 \mathrm{H}, \mathrm{OCH}_{2}\right) ; 7.04-7.10\left(\mathrm{~m}, 2 \mathrm{H}, \mathrm{CH}_{\mathrm{ar}}\right)$; 7.27-7.32 (m, 2H, $\left.\mathrm{CH}_{\mathrm{ar}}\right) ; 7.40-7.45\left(\mathrm{~m}, 2 \mathrm{H}, \mathrm{CH}_{\mathrm{ar}}\right) ; 7.57\left(\mathrm{t}, J=8.0 \mathrm{~Hz}, 1 \mathrm{H}, \mathrm{CH}_{\mathrm{ar}}\right) ; 7.59(\mathrm{~s}, 1 \mathrm{H}$, $\mathrm{CH}_{\text {triazole }}$ ); 8.02-8.05 (dd, $\left.J=4.0 \mathrm{~Hz}, J=1.6 \mathrm{~Hz} ; 2 \mathrm{H}, \mathrm{CH}_{\mathrm{ar}}\right) .{ }^{13} \mathrm{C} \mathrm{NMR}: \delta(\mathrm{ppm}): 53.8\left(\mathrm{CH}_{2}\right)$; $58.4\left(\mathrm{OCH}_{2}\right) ; 116.4\left(2 \mathrm{CH}_{\mathrm{ar}}\right) ; 116.7\left(\mathrm{CH}_{\text {triazole }}\right) ; 124.1\left(2 \mathrm{CH}_{\mathrm{ar}}\right) ; 128.8\left(2 \mathrm{CH}_{\mathrm{ar}}\right) ; 139.1\left(\mathrm{C}_{\mathrm{ar}}\right)$; $130.4\left(2 \mathrm{CH}_{\mathrm{ar}}\right) ; 130.6\left(\mathrm{C}_{\mathrm{ar}}\right) ; 133.6\left(\mathrm{CH}_{\mathrm{ar}}\right) ; 161.6\left(\mathrm{C}_{\text {triazole }}\right) ; 164.9\left(\mathrm{C}_{\mathrm{ar}}\right) ; 166.8\left(\mathrm{C}_{\text {ester }}\right)$. HRMS (ESI) $[\mathrm{M}+\mathrm{H}]^{+}$found $m / z$ : Calcd for $\mathrm{C}_{17} \mathrm{H}_{15} \mathrm{FN}_{3} \mathrm{O}_{2}$ : 312.1143; Found: 312.1142.

\subsection{Biology assay.}

\subsubsection{Cell culture.}

Fibrosarcoma lung carcinoma A-549, HT-1080, breast adenocarcinoma (MCF-7, and MDA-MB-231) cancer lines were kindly provided by Dr. P. Cours from INSERM (Tours, France). The Modified Eagle Medium (DMEM) was used to culture the MCF-7, A-549, and MDA-MB-231 cells, and (MEM) for HT-1080 with supplement $10 \%$ (v/v) fetal bovine serum (FBS) and $1 \%$ penicillin-streptomycin. The humidified atmosphere was used to incubate these cells at $+37{ }^{\circ} \mathrm{C}$ with $5 \% \mathrm{CO}_{2}$.

\subsubsection{Cytotoxicity and antiproliferative activity.}

A-549, MCF-7, HT-1080, and MDA-MB-231 cell lines were sowed in 96-well microculture plates using a density of $\left(5 \times 10^{3}\right.$ cells/well, cultured) for $24 \mathrm{~h}$ at $+37{ }^{\circ} \mathrm{C}$. Then, cells were treated with a concentration gradient of 1,2,3-triazole derivatives $(100,50,25,12.5$, and $6.25 \mu \mathrm{M}$ ) for $24 \mathrm{~h}$. Doxorubicin (TEVA Pharma S.A., Courbevoie, France) was used as a reference. For each treatment interval, viable cells were evaluated by 3-(4,5-dimethylthiazol2-yl)-2,5-diphenyl tetrazolium bromide (MTT) assays. Thereby, $5 \mathrm{mg} / \mathrm{mL}$ of MTT was used to incubate prepared cells for $4 \mathrm{~h}$ at $+37{ }^{\circ} \mathrm{C}$. The supernatant liquid was then discarded before dissolving formazan (the product of the reaction) by using $150 \mu \mathrm{L}$ of dimethyl sulfoxide (DMSO). A microplate reader (Thermo Scientific, Paris, France) was used to measure the absorbance at $570 \mathrm{~nm}$, and the $\mathrm{IC}_{50}$ was estimated using Graph Pad Prism7. 


\subsubsection{Annexin $\mathrm{V}$ binding assay.}

The HT-1080 cells were prepared at a density of $2 \times 10^{5} /$ wells followed by their incubation at $+37^{\circ} \mathrm{C}, 5 \% \mathrm{CO}_{2}$ overnight. The prepared cells were then treated with $\mathbf{8}$ at a concentration of 15 and $20 \mu \mathrm{M}$ for $24 \mathrm{~h}$. Further, these cells were harvested and washed twice with cold phosphate-buffered saline (PBS). Cells were detached and centrifuged for $5 \mathrm{~min}$, followed by their washing twice with cold PBS and before re-suspension in $100 \mu \mathrm{L}$ of Annexin V Binding Buffer (Annexin V Apoptosis Detection KIT with 7-AAD). Afterward, the incubation of the prepared cells was carried out at room temperature for $20 \mathrm{~min}$ in the dark. After staining, apoptotic cells were evaluated utilizing a Muse Cell Analyzer (Millipore).

\subsubsection{Caspase-3 activity.}

The caspase-3 activity was analyzed using the manufacturer's instructions. The different concentrations of $8(15$ and $20 \mu \mathrm{M})$ were used to treat the prepared cells. After $24 \mathrm{~h}$, the cells were harvested and washed with PBS, scrapped with the ice-cold lysis buffer Promega (Caspase assay kit). After staining, the apoptotic cells were examined by using a Muse Cell Analyzer (Millipore).

\subsubsection{Cell cycle assay.}

The treatment of cells was performed with 15 and $20 \mu \mathrm{M}$ of 8 for $24 \mathrm{~h}$, then harvested and washed with cold PBS. Ice-cold ethanol $70 \%$ was used to suspend the collected cells $\left(10^{6}\right.$ cells) for $12 \mathrm{~h}$ at $-20^{\circ} \mathrm{C}$. After washing, a quick centrifugation was used to pellet these cells and then were suspended once again in $1 \mathrm{~mL}$ of staining buffer $(100 \mathrm{mM}$ Tris, $\mathrm{pH}=7.4,150$ $\mathrm{mM} \mathrm{NaCl}, 1 \mathrm{mM} \mathrm{CaCl} 2,0.5 \mathrm{mM} \mathrm{MgCl}_{2}, 0.1 \%$ Nonidet $\mathrm{P}-40$ ) containing $3 \mu \mathrm{M}$ propidium iodide. The incubation of the prepared cells was performed $15 \mathrm{~min}$ at room temperature. Flow cytometry FACS Calibur (Becton-Dickinson, San Jose, CA) was used to analyze the DNA histograms and cell cycle phase distribution. The obtained data from 10,000 cells per sample were recorded and analyzed.

\subsubsection{Mitochondrial membrane potential measurement.}

The lipophilic cationic probe was used to investigate the mitochondrial membrane potential using JC-1 (Molecular Probes, Eugene, OR). Green fluorescence at $527 \mathrm{~nm}$ was obtained in monomeric forms of the dye in mitochondria with depolarized membranes. $10 \mu \mathrm{M}$ JC-1 reagent was added to the HT- 1080 cells seeded and treated with 15 and $20 \mu \mathrm{M}$ of 8 for $24 \mathrm{~h}$. Subsequently, these cells were incubated for $20 \mathrm{~min}$ at $+37{ }^{\circ} \mathrm{C}$ under the dark. Cells were then harvested and washed with PBS and centrifuged at $1500 \mathrm{rpm}$ for $5 \mathrm{~min}$, then suspended once again in $1 \mathrm{~mL}$ of cold PBS. The measurements were carried out using the Spectrofluorometer (RF-5301PC, Shimadzu, Tokyo, Japan).

\subsection{Docking and molecular modeling.}

The SYBYL-X 2.0 software (Tripos Inc., St. Louis, MO, USA) package installed on Windows 10 workstations was used to prepare the protein and ligands [33]. The crystal structure of human pro-matrix metalloproteinase-2 (PDB code: 1CK7) and metalloproteinase9 (PDB Code: 2OVZ) were obtained from Protein Data Bank [34], the protein and cocrystallized ligands were isolated from the complex. Each protein extracted from the complex 
was treated by removing all of the substructures, removing all of the water molecules, and adding hydrogen atoms without any conformation change. The prepared protein was used as the receptor for the docking experiment. Hydrogen atoms were added to ligands isolated from the complex and geometrically optimized with three steps: Firstly, optimization using Steepest Descent with Gasteiger-Marsili charges and Tripos force field; then optimization using conjugate gradient; and finally, optimization using BFGS [35]. The structures of all other molecules were built using the SKETCH model in sybyl-X 2.0, and geometrical optimizations were carried out using the above procedure. All the minimized compounds were docked into the active site with the created protomol derived from the co-crystallized ligand to generate the proposal binding pose of ligands. The ligand-receptor complex with the highest total score was considered the most stable binding conformation, which was selected to explore the possible binding mechanisms relying on several key factors, such as hydrogen bonds, hydrophobic interactions, and root-mean-square deviation (RMSD) values by SYBYL applications.

\section{Results and Discussion}

\subsection{Synthesis and characterization.}

The first step of our synthetic approach consisted of the preparation of organic azide derivatives. As reported earlier [36], the diazotization of aromatic amines by using $\mathrm{NaNO}_{2}$ followed by the addition of $\mathrm{NaN}_{3}$ affords the corresponding aromatic azides with yields ranging from 69 to $90 \%$. In the case of the benzyl azides, the corresponding benzyl bromide derivative reacted with $\mathrm{NaN}_{3}$ in water/acetone $(1: 3 \mathrm{v} / \mathrm{v})$ at room temperature under vigorous stirring to afford the desired benzyl azide derivatives as yellow oils. The diethyl (3azidopropyl)phosphonate was prepared by refluxing diethyl (3-bromopropyl)phosphonate with $\mathrm{NaN}_{3}$ in acetone/water solvent mixtures overnight. The chemical structures of the prepared azide derivatives were confirmed by analyzing the crude product using FTIR spectroscopy, and they were used directly in the next step without any further purification. They all exhibit a strong absorption band at $2070-2110 \mathrm{~cm}^{-1}$ which is attributed to the $v_{\text {as }}\left(\mathrm{N}_{3}\right)$ stretching vibration of the azide group. Terminal alkyne derivatives were prepared either by simple alkylation of commercially available phenol using propargyl bromide and $\mathrm{K}_{2} \mathrm{CO}_{3}$ in acetone at room temperature or by esterification of benzoyl chloride with propargyl alcohol in the presence of triethylamine ( $\left.\mathrm{NEt}_{3}\right)$ as a base in dichloromethane [37] (see Scheme 1). The resulting terminal alkynes were obtained in excellent yields.

The synthesis of the 1,2,3-triazole derivatives 1-4 and 7-10 was accomplished through the copper-catalyzed [3+2] cycloaddition reaction between terminal alkynes and azides using $\mathrm{CuSO}_{4} \cdot 5 \mathrm{H}_{2} \mathrm{O}$ as precatalyst and sodium ascorbate as a reduction agent in water at room temperature. The 1,4-disubstituted 1,2,3-triazole derivatives were obtained in good to excellent yields. The remaining 1,4-disubstituted $\beta$-hydroxytriazoles 5 and 6 were prepared by slightly modifying the described protocol using a one-pot reaction from an epoxide, sodium azide, and alkynes the presence of $\mathrm{Cu}(\mathrm{OAc})_{2} \cdot \mathrm{H}_{2} \mathrm{O}$ in water [38-40]. The structures of all products were characterized using ${ }^{1} \mathrm{H}$ NMR, ${ }^{13} \mathrm{C}$ NMR, FTIR spectroscopies, and HRMS analysis (see Figures 1S-S30 in supplementary materials). The FTIR spectrum of 6 taken as an example, shows absorption bands at $3415,1234,1060 \mathrm{~cm}^{-1}$ indicating the presence of $-\mathrm{OH}, \mathrm{C}-\mathrm{N}$, and C-O groups, respectively. The ${ }^{1} \mathrm{H}$ NMR spectrum of compound 10 shows two distinctive singlet signals at around 5.47 and $5.54 \mathrm{ppm}$, showing the attachment of two methylene groups $\left(\mathrm{CH}_{2}\right)$ to the 1,2,3-triazole moiety. Moreover, the presence of the triazole moiety was confirmed by 
the occurrence of the most informative singlet signal at $7.59 \mathrm{ppm}$. All hydrogen atoms of the aromatic rings of the prepared 1,2,3-triazoles are displayed in the ranges 7.04-7.57 and 8.02$8.05 \mathrm{ppm}$. The ${ }^{13} \mathrm{C}$ NMR spectrum of 10 indicates the presence of two methylene carbons bonded to the phenolate ring's oxygen atom and the nitrogen atom of the triazole moiety, respectively. The most prominent carbon signals $\left(\mathrm{CH}_{\text {triazole }}\right)$ were observed around $116.7 \mathrm{ppm}$. The ${ }^{1} \mathrm{H}$ NMR spectrum of compound 9 shows a slight shifting of the characteristics peaks compared with compound 10. The signals for methylene groups were found at 5.21 and 5.55 $\mathrm{ppm}$, respectively. The triazole moiety was confirmed by the presence of a singlet at $7.46 \mathrm{ppm}$. The characteristic carbon signal assigned to the $\mathrm{CH}$ group of 1,2,3-triazole ring was shifted at 128.6 compared to compound 9, $116.7 \mathrm{ppm}$. Furthermore, high-resolution mass spectrometry of 6 reveals a molecular ion peak $[\mathrm{M}+\mathrm{H}]^{+}$at $m / z=296.1387$, which coincides with the expected molecular formula $\mathrm{C}_{17} \mathrm{H}_{15} \mathrm{~N}_{3} \mathrm{O}_{2}$.

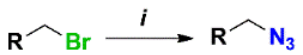<smiles>[R]c1ccc(C)cc1</smiles>

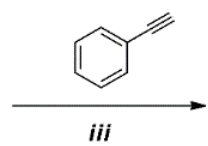<smiles>C#CCSc1ccccc1</smiles>
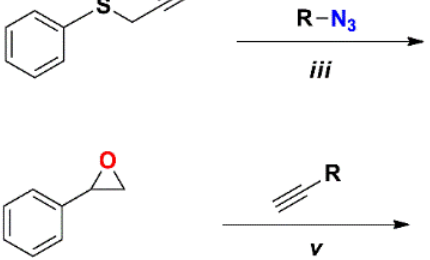<smiles>[R]c1cn(C(CO)c2ccccc2)nn1</smiles>

3: $\mathbf{R =}$<smiles>COc1ccc(C(C)(C)C)cc1</smiles><smiles>[R]C#CCC#CC</smiles>

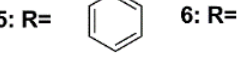

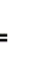<smiles>CCOc1ccccc1</smiles><smiles>O=C(Cl)c1ccccc1</smiles><smiles>[R]n1cc(COC(=O)c2ccccc2)nn1</smiles>

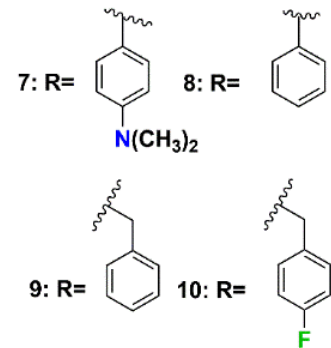

Scheme 1. Synthetic route of the 1,2,3-triazole derivatives 1-10 under study. Reagents and conditions: (i) $\mathrm{NaN}_{3}$, acetone, $56{ }^{\circ} \mathrm{C}, 24 \mathrm{~h}$, hexane/ethyl acetate $(9: 1 \mathrm{v} / \mathrm{v})$; (ii) Conc. $\mathrm{HCl}, \mathrm{H}_{2} \mathrm{O}, \mathrm{NaNO}_{2}, \mathrm{NaN}_{3}, 0{ }^{\circ} \mathrm{C}$; (iii) sodium ascorbate (5 mol\%), $\mathrm{CuSO}_{4} \cdot 5 \mathrm{H}_{2} \mathrm{O}(1 \mathrm{~mol} \%), \mathrm{H}_{2} \mathrm{O}(5 \mathrm{~mL})$, r.t., 8 h. (iv) $\mathrm{NEt}_{3}$, propargyl alcohol, $\mathrm{CH}_{2} \mathrm{Cl}_{2}, 0-10{ }^{\circ} \mathrm{C}$; (v) $\mathrm{NaN}_{3}$ (1.1 equiv), $\mathrm{Cu}(\mathrm{OAc})_{2} \cdot \mathrm{H}_{2} \mathrm{O}(5 \mathrm{~mol} \%), \mathrm{H}_{2} \mathrm{O}(10 \mathrm{~mL}), 60^{\circ} \mathrm{C}$.

\subsection{Anticancer activity.}

\subsubsection{In vitro cytotoxic activity.}

Antiproliferative activity was used to analyze the effects of the 1,2,3-triazole derivatives 1-10 on the cell growth of four cancer cell lines, using breast adenocarcinoma (MCF-7 and MDA-MB-231), lung carcinoma A-549, and fibrosarcoma HT-1080. The targeted cells were treated with a wide range of concentrations [41,42] of 1-10 for $24 \mathrm{~h}$. The MTT assay was used to detect the cytotoxic activity of the synthesized compounds, and the $\mathrm{IC}_{50}$ values 
(concentration required to inhibit tumor cell proliferation by 50\%) are presented in Table 1 with doxorubicin as the standard reference drug.

Table 1. Cytotoxic activities of 1-10 against human MDA-MB-231, A-549, MCF-7, and HT-1080 cells for $24 \mathrm{~h}$. Compound

\begin{tabular}{|c|c|c|c|c|}
\hline \multirow{2}{*}{ ompound } & \\
\hline & HT1080 & A549 & MCF-7 & MDA-MB-231 \\
\hline 1 & $>50$ & $>50$ & 47.28 & $>50$ \\
\hline 2 & $>50$ & $>50$ & 39.96 & $>50$ \\
\hline 3 & $>50$ & $>50$ & 35.21 & $>50$ \\
\hline 4 & $>50$ & $>50$ & $>50$ & 46.19 \\
\hline 5 & 18.32 & 22.59 & 31.65 & 25.61 \\
\hline 6 & $>50$ & 45.29 & $>50$ & 49.02 \\
\hline 7 & 25.64 & 24.05 & 19.34 & 28.38 \\
\hline 8 & 15.13 & 21.25 & 18.06 & 16.32 \\
\hline 9 & 22.54 & 28.32 & 31.82 & 20.01 \\
\hline 10 & 21.72 & 35.00 & 28.75 & 31.25 \\
\hline Doxorubicin & 4.96 & 6.36 & 5.46 & 5.13 \\
\hline
\end{tabular}

The results indicate that most compounds exhibit lower to moderate antiproliferative activities against the four selected cancer lines by comparison with the known anticancer chemotherapy drug doxorubicin. Compound 8 with the phosphonate group linked to the triazole moiety is the most active compound, among the evaluated series of 1,2,3-triazoles 110 , for cell growth inhibition against the four tested cancer cell lines, HT-1080 = 15.13, A-549 $=21.25, \mathrm{MCF}-7=18.06$, and MDA-MB-231 = $16.32 \mu \mathrm{M}$. Besides, 1,2,3-triazole derivatives 5 and 7 have revealed interesting $\mathrm{IC}_{50}$ values between 18.32 and $31.65 \mu \mathrm{M}$ versus all the selected cells.

\subsubsection{Annexin V-binding.}

Cell death is an important factor in determining the potential mechanism of action for the investigated compounds. To analyze apoptosis, we chose the most active compound 8 to determine its mode of action in the HT-1080 cells. These cells were treated with 8 (15 and 20 $\mu \mathrm{M}$ ), and the selected cancer lines were analyzed using Annexin V-FITC/PI labeling by flow cytometry. As shown in Fig. 2, 8 induced cell apoptosis in a dose-dependent manner with a slight increase in early and late stages of apoptosis from 1.34 (Control) to $11.22 \%$ for $15 \mu \mathrm{M}$ and $18.60 \%$ for $20 \mu \mathrm{M}$.

\subsubsection{Caspase-3 activity assay.}

Caspase-3, or executioner caspase, is a family of conserved cysteine-aspartic acid proteases that plays a fundamental role in the execution phase of apoptosis by involving one or more caspases $[43,44]$. To confirm whether caspase- 3 activation indicates an apoptotic mode of cell death, we investigated the activation of caspase- 3 in the presence of phosphonatecontaining 1,2,3-triazole 8 treated HT-1080 cells with 15 and $20 \mu \mathrm{M}$ for $24 \mathrm{~h}$. The obtained data shown in Fig. 3 confirm no involvement of caspase- 3 in the activation process of apoptosis induced in HT-1080 cells by compound 8 . In statistical terms, we notice a very small proportion of caspase- 3 activity $(5.07 \%)$ after $24 \mathrm{~h}$ of treatment $(15 \mu \mathrm{M})$. A slight increase has been noted in the same time incubation with $20 \mu \mathrm{M}(+0.48 \%)$. These results indicate that compound 8 apoptosis appeared by the apoptotic pathway independently on the caspase-3. 


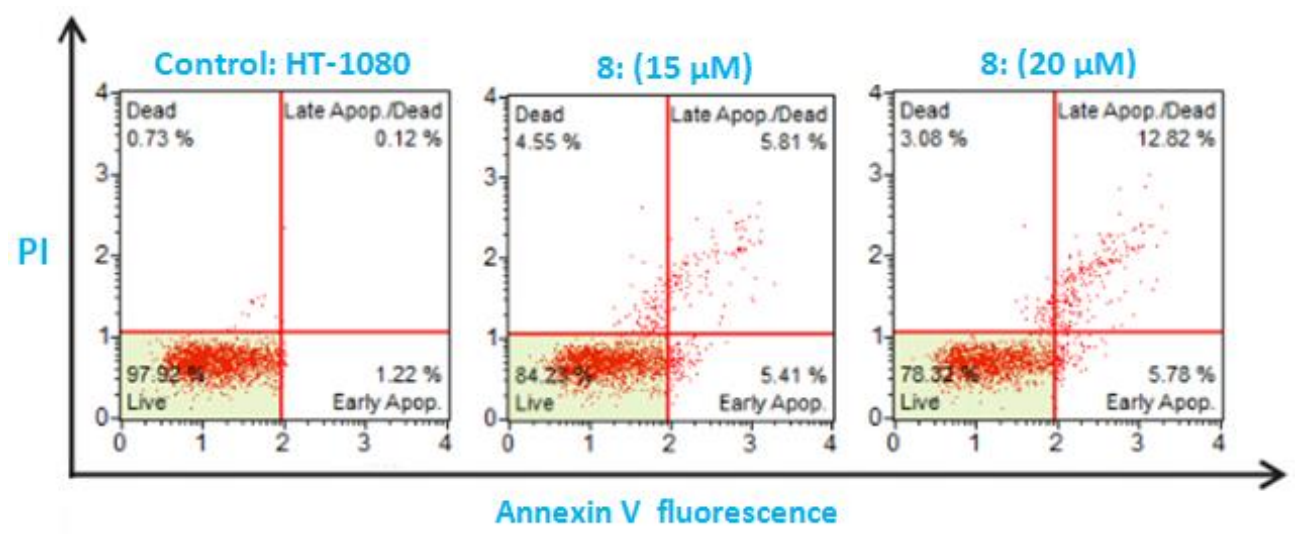

Figure 2. Detection and analysis of Annexin V-FITC/PI staining of the treated HT-1080 cells with 15 and 20 $\mu \mathrm{M}$ of 8 for $24 \mathrm{~h}$.
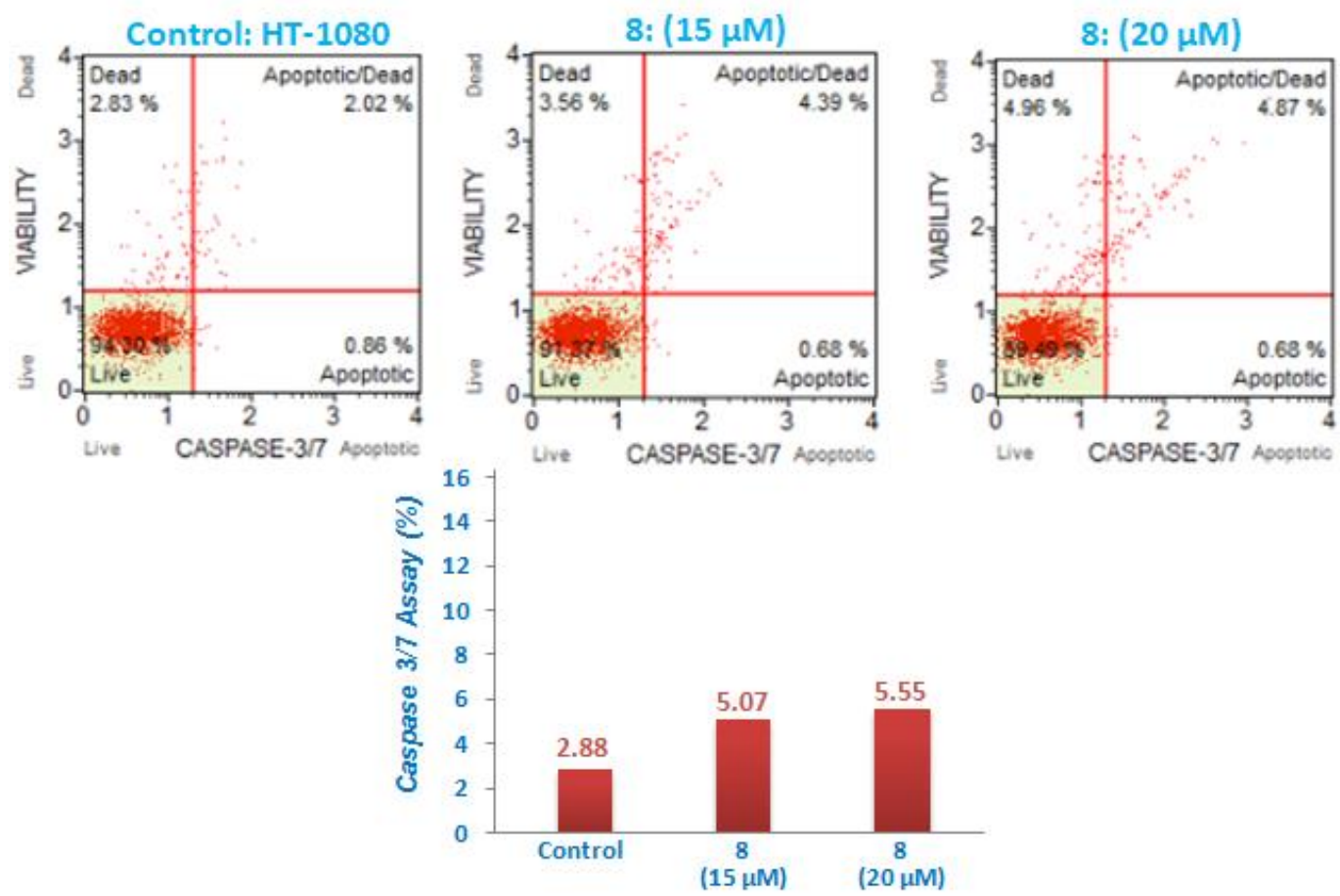

Figure 3. Colorimetric assay of the caspase-3 activity. HT-1080 cells were treated with 15 and $20 \mu \mathrm{M}$ of 8 for $24 \mathrm{~h}$.

3.2.4. Investigation of cell cycle distribution.

Appearances of two new indistinguishable cells come from a cell division through several phases of the cell cycle progression, such as G1 (cell enlargement), S (DNA replication), G2 (repairing of new DNA), and $\mathrm{M}$ phases (nuclear division). Further, we evaluated the effect of 8 on the cell cycle distribution to determine whether a selected product could cause alterations in the cell cycle progression of the HT-1080 cells by using flow cytometric analysis after treatment with 15 and $20 \mu \mathrm{M}$ for $24 \mathrm{~h}$ (Fig. 4). We observed an increase in the proportion of cells in the G0/G1 phase by increasing concentrations of 8 (55.80 to $64.40 \%$ ); on the other hand, the percentage of cells in the $\mathrm{S}$ and $\mathrm{G} 2 / \mathrm{M}$ phases decreased marginally after treatment ( $\mathrm{S}: 11.50$ to $9.10 \%$ \& G2/M: 24.80 to $20.70 \%$ ), by comparison to the control cells. These data revealed that when treating HT-1080 with compound 8, the arrest of the cell cycle at the G0/G1 phase occurs in a dose-dependent manner. 


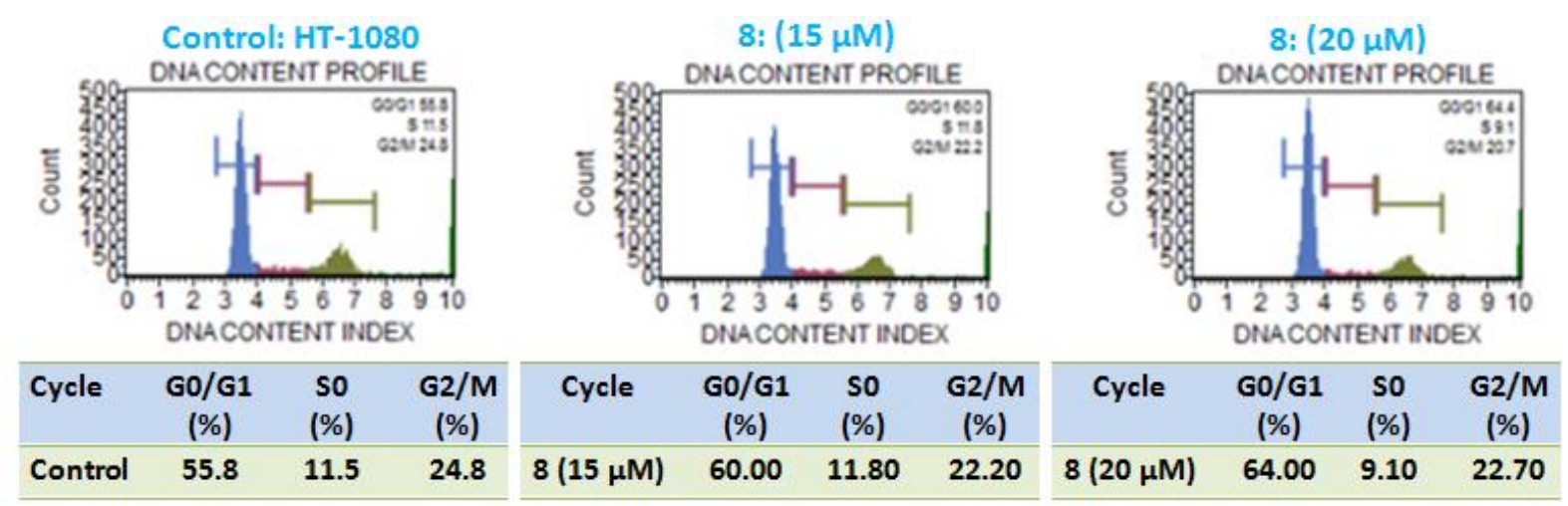

Figure 4. Effects of compound 8 on the cell cycle phase distribution in HT-1080 cells after treatment with 15 and $20 \mu \mathrm{M}$ during $24 \mathrm{~h}$ by using propidium iodide to determine the DNA fluorescence.

\subsubsection{Mitochondrial membrane potential $(\Delta \Psi \mathrm{m})$ depolarization.}

Dysfunction of the mitochondria membrane potential (MMP, $\Delta \Psi \mathrm{m}$ ) of the involved cells in apoptotic cell death occurs by releasing various specific proteins to trigger apoptosis [41]. To this end, mitochondrial disfunction was investigated based on the measurement of the MMP index through flow cytometry using JC-1 dye as a fluorescent probe. HT-1080 cells were treated with compound 8 at 15 and $20 \mu \mathrm{M}$ concentrations for $24 \mathrm{~h}$. As shown in Fig. 5, this compound induces a mitochondrial membrane potential and an increase in a concentrationdependent manner. As a consequence, it causes apoptosis independent of the mitochondrial pathway.

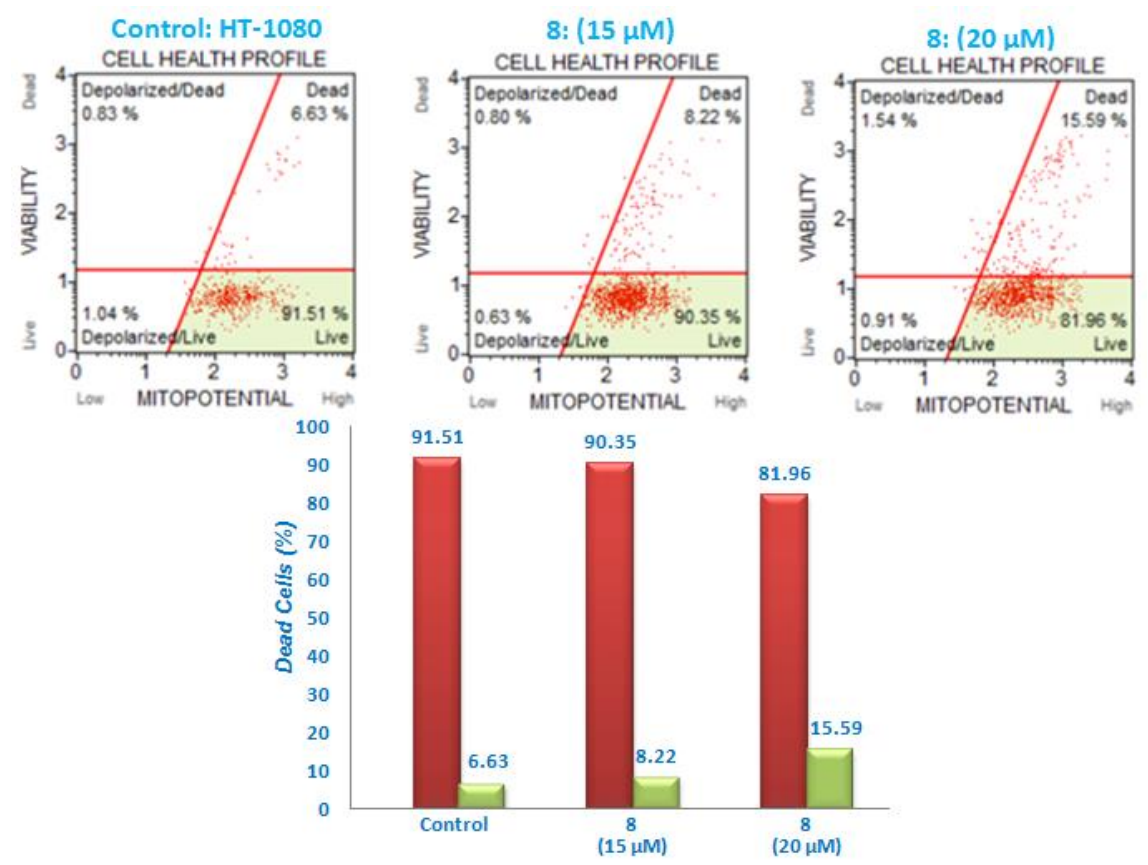

Figure 5. Compound 8 induces a potential mitochondrial loss in the HT-1080 fibrosarcoma cells after treatment of various concentrations ( 15 and $20 \mu \mathrm{M})$ during $24 \mathrm{~h}$.

\subsection{Molecular docking study.}

MMP-2 and MMP-9 matrix metalloproteinases are considered models for tumor development and angiogenesis, which means that the set-up of potent MMP-2/MMP-9 inhibitors should be the major goal in cancer drug discovery. To explain the potential inhibition activity of the 1,2,3-triazole derivative 8 as anticancer agent, the molecular docking study was 
applied using Surflex-Docking and Discovery studio package for visualization [33]. Compound 8 docked to the crystallographic structures of PDB ID:1CK7 for MMP-2, and PDB ID:2OVZ for MMP-9 downloaded from Protein Data Bank [34]. The docking protocol was investigated by using the co-crystallized ligand into the active site with an RMSD of $1.42 \AA$ and $0.46 \AA$ for both MMP-2 and MMP-9 receptors, respectively (Fig. 6). The binding affinities were confirmed by the total scores expressed in $-\log 10\left(K_{\mathrm{d}}\right)$ units. The protein structure optimization occurred by adding hydrogen and eliminating the water molecules using the Sybyl-x 2.0 software [45].

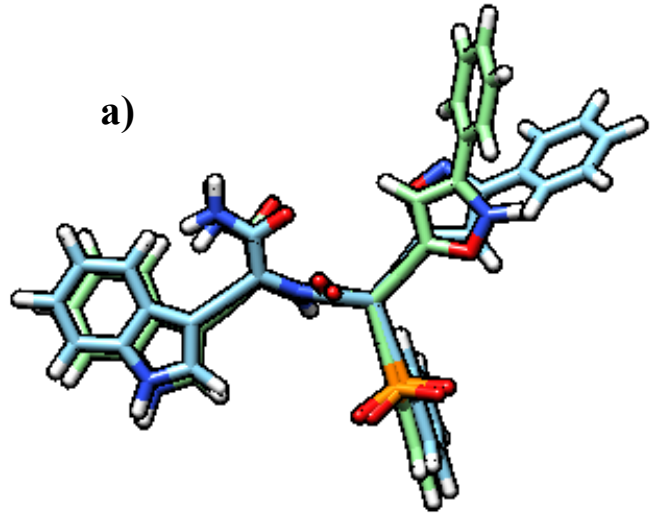

b)

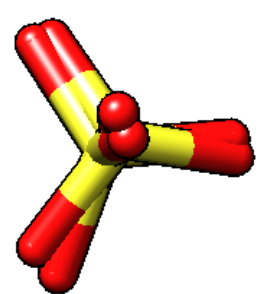

Figure 6. The superimposed image of the redocked and co-crystal ligand of both MMP-9 receptor (a) and MMP-2 receptor (b).
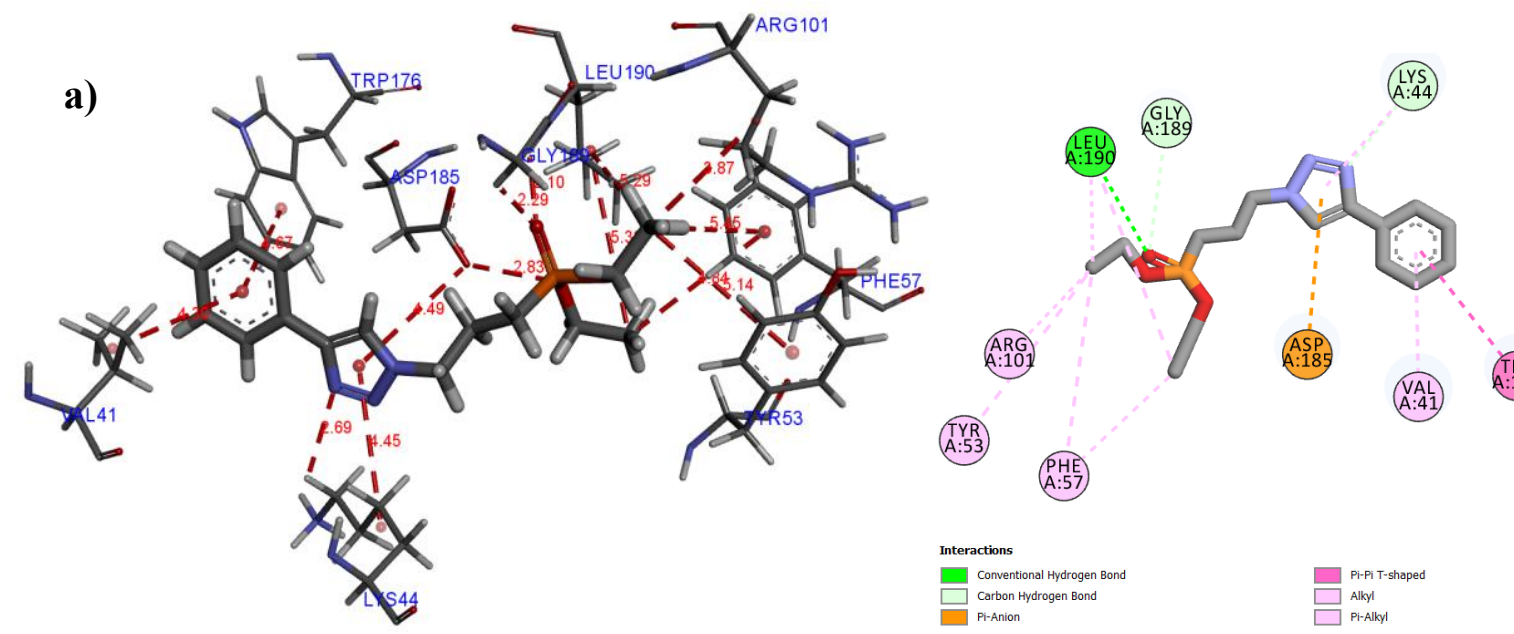

b)

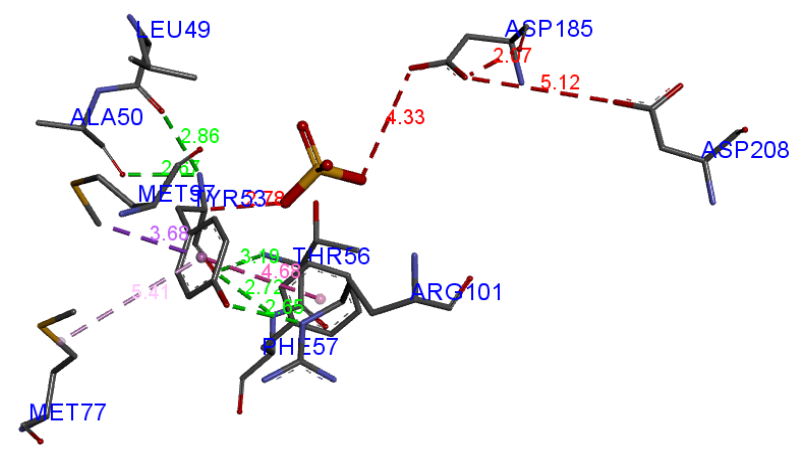

Figure 7. The interactions of compound 8 (a) and co-crystallized structure (b) with MMP-2 receptor (PDB ID: 1CK7). 
The in-silico results of molecular docking molecular compound 8 into the MMP-2 receptor (PDB ID: 1CK7) showed that the phenyl group stabilizes molecule 8 by alkyl and $\pi-\pi$ interactions with VAL A:41 and TRP A:176 residues with a distance of 4.3 and $4.67 \AA$, respectively. In addition, the triazole ring establishes $\pi$-anion and carbon-hydrogen bond interactions with the ASP A:185 and LYS A:44 residues with distances of 4.49 and $4.45 \AA$, respectively. Remarkably, the presence of the phosphonate group stabilizes compound 8 by an $\pi$-alkyl interaction with the ARG A:101; TYR A:53, PHE A:57 residues with distances of 3.87; 5.14 and $4.84 \AA$, respectively, as well as carbon-hydrogen bond and hydrogen bonding interactions with the GLY A:189 and LEU A:190 residues, with distances of 2.29 and $2.10 \AA$, respectively (Fig. 7). At the same time, the co-crystallized structure of the MMP-2 receptor (sulfate) shows two interactions, namely $\pi$-anion interaction with ASP A:185 with a distance of $4.33 \AA$, and carbon-hydrogen interaction with TYR A:53 with a distance of $2.78 \AA$. The molecule 8 and co-crystallized structure are stabilized by carbon-hydrogen bond interactions with ASP A:185 and TYR A:53 residues, showing score functions of 3.2 and 1.4, respectively.
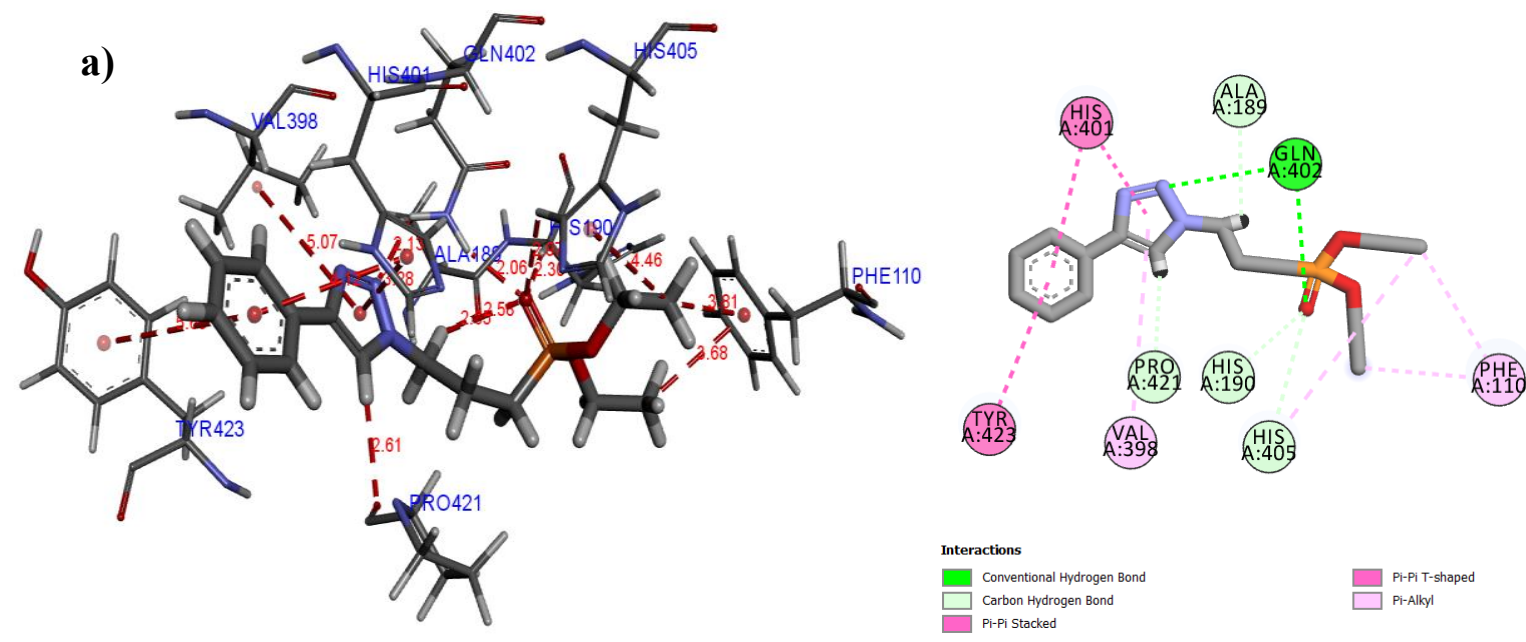

b)
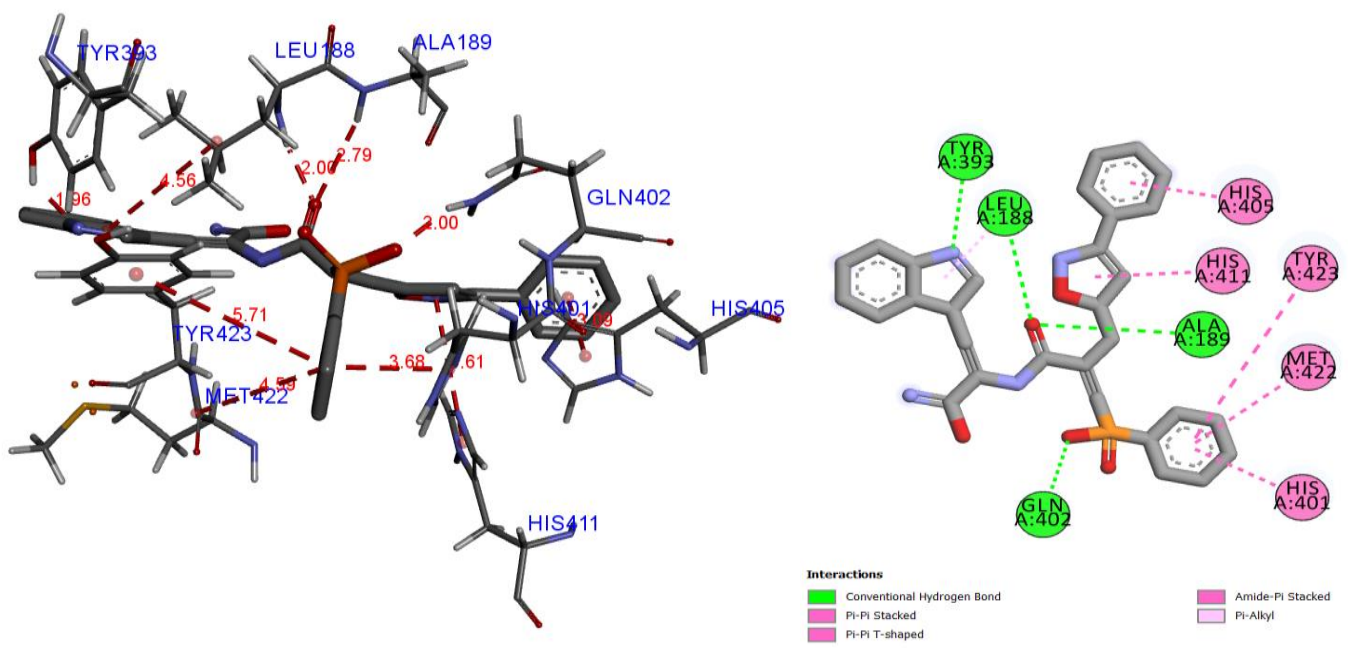

Figure 8. The interactions of compound 8 (a) and co-crystallized structure (b) with the MMP-9 receptor (PDB ID: 2OVZ).

The molecular docking of 8 into the MMP-9 receptor presented in Fig. 8 shows $\pi-\pi$ interactions between the phenyl group and HIS A:401 and TYR A:423 residues with distances of 4.12 and $5.69 \AA$, respectively. The triazole ring stabilizes the docking of 8 by different types of interactions with the HIS A:401, VAL A:398, PRO A:421, and GLN A:402 residues with 
distances of 3.28; 5.07; 2.61 and $2.06 \AA$, respectively. The presence of the phosphonate group in 8 leads to $\pi$-alkyl interactions with the PHE A: 110 residue with a distance of $3.68 \AA$, carbonhydrogen bonds with the HIS A:190 and HIS A: 405 residues with distances of 2.30 and 4.46 $\AA$, respectively, and also hydrogen bonds with the GLN A: 402 residues with a distance of 2.13 $\AA$, causing the stabilization of 8 into the receptor pocket and explaining the inhibition observed experimentally. While the co-crystallized structure of the MMP-9 receptor is stabilized by four hydrogen bonds, including TYR A:393; LEU A:188; ALA A:189, and GLN A:402 residues, with a distance of $1.96 ; 2.00 ; 2.79$, and $2.00 \AA$, respectively. The compound 8 and cocrystallized structure are stabilized by hydrogen bonding with GLN A:402 residue showing a score function of 3.7 and 5.1, respectively.

The blue and green colors around the phosphonate group shown in Fig. 9 for both MMP-2 and MMP-9 receptors indicate this fragment's hydrophilic and hydrogen bond acceptor characters, which stabilizes this molecule in the MMP receptors pocket. The blue and green contours indicate that hydrophilic groups with hydrogen bond acceptor character stabilize ligand into receptor pocket; this indicates the relevance of triazole moiety in stabilizing the studied 1,2,3-triazole compound.

A)
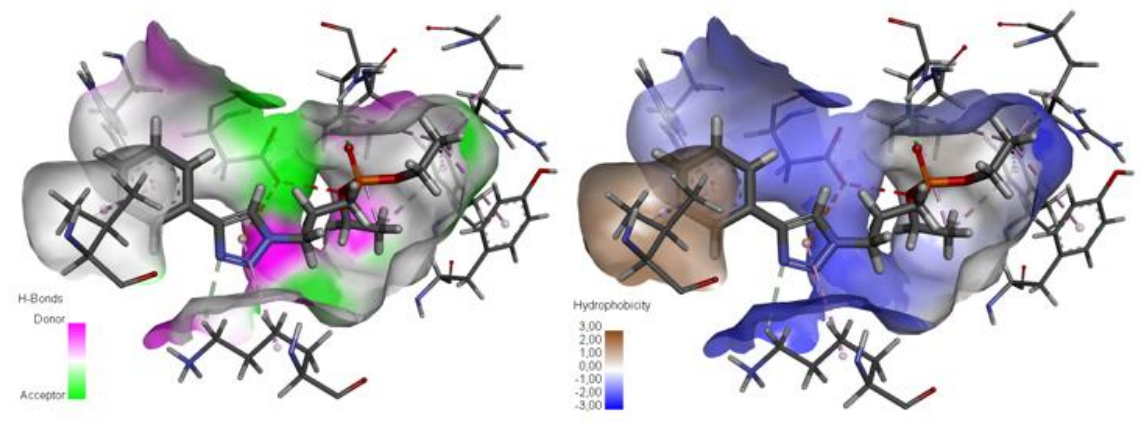

B)
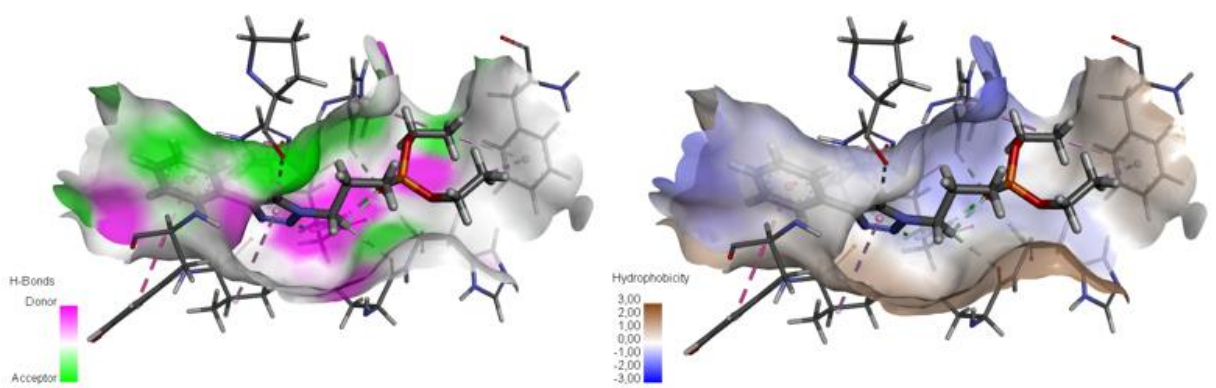

Figure 9. Molecular docking of compound 8 with (A) 1CK7 (MMP-2) and (B) 2OVZ (MMP-9).

\section{Conclusions}

A series of 1,2,3-triazole derivatives were straightforwardly synthesized by click chemistry using copper-catalyzed azide-alkyne [3+2] cycloaddition reactions of various functional organic azides and terminal alkynes and followed by the evaluation of their anticancer activity against certain human cancer cell lines. The preliminary tests of cytotoxicity showed that the prepared 1,2,3-triazole derivatives exhibit moderate anticancer activity. Among them, the 1,2,3-triazole derivative 8 bearing phosphonate group exhibits the best activity against HT- 1080 cells with a value for $\mathrm{IC}_{50}$ of $15.13 \mu \mathrm{M}$. The phosphonate derivative was selected for the study of its mechanism of action against HT-1080 cells. The results obtained revealed that this derivative could induce apoptosis by an independent pathway of the 
caspase-3 associated with increasing the mitochondrial membrane potential and arresting the cell cycle at the G0/G1 phase. Molecular docking studies of 8 into the MMP-2 and MMP-9 metalloproteinases receptors demonstrated the relevance of the triazole scaffolds and the pendant phosphonate group in establishing $\pi$-anion, $\pi$-alkyl, and hydrogen bonding type interactions with residual components in the active MMP pocket. Although moderate in terms of anticancer activities, these results may help in understanding the inhibition action of the triazole framework against the cancer cell lines, in synergy with the two functional pendent groups at the 1- and 4-positions at the 1,2,3-triazole moiety, especially when they are potentially anticancer pharmacophores.

\section{Funding}

This research received no external funding.

\section{Acknowledgments}

The Ministerio Español de Economia y Competitividad (MINECO) (Project CTQ201675068P) and Université de Reims Champagne-Ardenne France are gratefully acknowledged for their generous support.

\section{Conflicts of Interest}

The authors declare no conflict of interest.

\section{References}

1. Mingli, Y.; Hailin, L.; Yazhou, Z.; Xiujun, W.; Zhi, X. Moxifloxacin-Isatin Hybrids Tethered by 1,2,3Triazole and Their Anticancer Activities. Current Topics in Medicinal Chemistry 2020, 20, 1461-1467, https://doi.org/10.2174/1568026620666200128144825.

2. Bray, F.; Ferlay, J.; Soerjomataram, I.; Siegel, R.L.; Torre, L.A.; Jemal, A. Global Cancer Statistics 2018: GLOBOCAN Estimates of Incidence and Mortality Worldwide for 36 Cancers in 185 Countries. CA Cancer J Clin 2018, 68, 394-424, https://doi.org/10.3322/caac.21492.

3. Nurgali, K.; Jagoe, R.T.; Abalo, R. Editorial: Adverse Effects of Cancer Chemotherapy: Anything New to Improve Tolerance and Reduce Sequelae? Front Pharmacol 2018, 9, 245, https://doi.org/10.3389/fphar.2018.00245.

4. Pilleron, S.; Soto-Perez-de-Celis, E.; Vignat, J.; Ferlay, J.; Soerjomataram, I.; Bray, F.; Sarfati, D. Estimated Global Cancer Incidence in the Oldest Adults in 2018 and Projections to 2050. International Journal of Cancer 2021, 148, 601-608, https://doi.org/10.1002/ijc.33232.

5. Lorscheider, M.; Gaudin, A.; Nakhlé, J.; Veiman, K.-L.; Richard, J.; Chassaing, C. Challenges and Opportunities in the Delivery of Cancer Therapeutics: Update on Recent Progress. Therapeutic Delivery 2021, 12, 55-76, https://doi.org/10.4155/tde-2020-0079.

6. Lauria, A.; La Monica, G.; Bono, A.; Martorana, A. Quinoline Anticancer Agents Active on DNA and DNAInteracting Proteins: From Classical to Emerging Therapeutic Targets. European Journal of Medicinal Chemistry 2021, 220, https://doi.org/10.1016/j.ejmech.2021.113555.

7. Thirumurugan, P.; Matosiuk, D.; Jozwiak, K. Click Chemistry for Drug Development and Diverse ChemicalBiology Applications. Chem. Rev. 2013, 113, 4905-4979, https://doi.org/10.1021/cr200409f.

8. Katerina, I.S.; Lozan, T.T.; Nataliya, P.B.; Mauricio, A.P.; Irena, P.K. Developments in the Application of 1,2,3-Triazoles in Cancer Treatment. Recent Patents on Anti-Cancer Drug Discovery 2020, 15, 92-112, https://doi.org/10.2174/1574892815666200717164457.

9. Liang, T.; Sun, X.; Li, W.; Hou, G.; Gao, F. 1,2,3-Triazole-Containing Compounds as Anti-Lung Cancer Agents: Current Developments, Mechanisms of Action, and Structure-Activity Relationship. Frontiers in Pharmacology 2021, 12, https://doi.org/10.3389/fphar.2021.661173.

10. Brandão, G.C.; Rocha Missias, F.C.; Arantes, L.M.; Soares, L.F.; Roy, K.K.; Doerksen, R.J.; Braga de Oliveira, A.; Pereira, G.R. Antimalarial Naphthoquinones. Synthesis via Click Chemistry, in Vitro Activity, Docking to PfDHODH and SAR of Lapachol-Based Compounds. Eur J Med Chem 2018, 145, 191-205, https://doi.org/10.1016/j.ejmech.2017.12.051. 
11. Huang, G.; Solano, C.M.; Melendez, J.; Yu-Alfonzo, S.; Boonhok, R.; Min, H.; Miao, J.; Chakrabarti, D.; Yuan, Y. Discovery of Fast-Acting Dual-Stage Antimalarial Agents by Profiling Pyridylvinylquinoline Chemical Space via Copper Catalyzed Azide-Alkyne Cycloadditions. European Journal of Medicinal Chemistry 2021, 209, https://doi.org/10.1016/j.ejmech.2020.112889.

12. Kaushik, C.P.; Kumar, K.; Lal, K.; Narasimhan, B.; Kumar, A. Synthesis and Antimicrobial Evaluation of 1,4-Disubstituted 1,2,3-Triazoles Containing Benzofused N-Heteroaromatic Moieties. Monatsh Chem 2016, 147, 817-828, https://doi.org/10.1007/s00706-015-1544-2.

13. Kumar, S.; Prasad, S.; Kumar, B.; Gautam, H.K.; Sharma, S.K. Synthesis of Novel Triazolyl Pyranochromen2(1H)-Ones and Their Antibacterial Activity Evaluation. Med Chem Res 2016, 25, 1057-1073, https://doi.org/10.1007/s00044-016-1549-3.

14. Nandikolla, A.; Srinivasarao, S.; Khetmalis, Y.M.; Kumar, B.K.; Murugesan, S.; Shetye, G.; Ma, R.; Franzblau, S.G.; Sekhar, K.V.G.C. Design, Synthesis and Biological Evaluation of Novel 1,2,3-Triazole Analogues of Imidazo-[1,2-a]-Pyridine-3-Carboxamide against Mycobacterium Tuberculosis. Toxicology in Vitro 2021, 74, https://doi.org/10.1016/j.tiv.2021.105137.

15. Nejadshafiee, V.; Naeimi, H.; Zahraei, Z. Efficient Synthesis and Antibacterial Evaluation of Some Substituted $\quad \beta$-Hydroxy-1,2,3-Triazoles. Chemical Data Collections 2020, 28, https://doi.org/10.1016/j.cdc.2020.100443.

16. Scarim, C.B.; Pavan, F.R. Thiazole, Triazole, Thio- and Semicarbazone Derivatives - Promising Moieties for Drug Development for the Treatment of Tuberculosis. European Journal of Medicinal Chemistry Reports 2021, 1, https://doi.org/10.1016/j.ejmcr.2021.100002.

17. Bozorov, K.; Zhao, J.; Aisa, H.A. 1,2,3-Triazole-Containing Hybrids as Leads in Medicinal Chemistry: A Recent Overview. Bioorganic \& Medicinal Chemistry 2019, 27, 3511-3531, https://doi.org/10.1016/j.bmc.2019.07.005.

18. Feng, L.-S.; Zheng, M.-J.; Zhao, F.; Liu, D. 1,2,3-Triazole Hybrids with Anti-HIV-1 Activity. Archiv der Pharmazie 2021, 354, https://doi.org/10.1002/ardp.202000163.

19. da Rocha, D.R.; Santos, W.C.; Lima, E.S.; Ferreira, V.F. Synthesis of 1,2,3-Triazole Glycoconjugates as Inhibitors of $\alpha$-Glucosidases. Carbohydrate Research 2012, 350, 14-19, https://doi.org/10.1016/j.carres.2011.12.026.

20. Jabeen, F.; Shehzadi, S.A.; Fatmi, M.Q.; Shaheen, S.; Iqbal, L.; Afza, N.; Panda, S.S.; Ansari, F.L. Synthesis, in Vitro and Computational Studies of 1,4-Disubstituted 1,2,3-Triazoles as Potential $\alpha$-Glucosidase Inhibitors. Bioorg Med Chem Lett 2016, 26, 1029-1038, https://doi.org/10.1016/j.bmcl.2015.12.033.

21. Kaur, J.; Saxena, M.; Rishi, N. An Overview of Recent Advances in Biomedical Applications of Click Chemistry. Bioconjugate Chem. 2021, 32, 1455-1471, https://doi.org/10.1021/acs.bioconjchem.1c00247.

22. Dixit, D.; Verma, P.K.; Marwaha, R.K. A Review on 'Triazoles': Their Chemistry, Synthesis and Pharmacological Potentials. J Iran Chem Soc 2021, 18, 2535-2565, https://doi.org/10.1007/s13738-02102231-X.

23. Xu, Z.; Zhao, S.-J.; Liu, Y. 1,2,3-Triazole-Containing Hybrids as Potential Anticancer Agents: Current Developments, Action Mechanisms and Structure-Activity Relationships. Eur J Med Chem 2019, 183, https://doi.org/10.1016/j.ejmech.2019.111700.

24. Bourakadi, K.E.; Mekhzoum, M.E.M.; Saby, C.; Morjani, H.; Chakchak, H.; Merghoub, N.; Qaiss, A.; Kacem, E.; Bouhfid, R. Synthesis, Characterization and in Vitro Anticancer Activity of ThiabendazoleDerived 1,2,3-Triazole Derivatives. New J. Chem. 2020, 44, 12099-12106, https://doi.org/10.1039/C9NJ05685H.

25. Jain, A.N. Surflex: Fully Automatic Flexible Molecular Docking Using a Molecular Similarity-Based Search Engine. J Med Chem 2003, 46, 499-511, https://doi.org/10.1021/jm020406h.

26. Sun, J.; Mei, H. Docking and 3D-QSAR Investigations of Pyrrolidine Derivatives as Potent Neuraminidase Inhibitors. Chem Biol Drug Des 2012, 79, 863-868, https://doi.org/10.1111/j.1747-0285.2012.01330.x.

27. Bahsis, L.; Ayouchia, H.B.E.; Anane, H.; Pascual-Álvarez, A.; Munno, G.D.; Julve, M.; Stiriba, S.-E. A Reusable Polymer-Supported Copper(I) Catalyst for Triazole Click Reaction on Water: An Experimental and Computational Study. Applied Organometallic Chemistry 2019, 33, https://doi.org/10.1002/aoc.4669.

28. Ben El Ayouchia, H.; ElMouli, H.; Bahsis, L.; Anane, H.; Laamari, R.; Gómez-García, C.J.; Julve, M.; Stiriba, S.-E. Hyperbranched Polyethylenimine-Supported Copper(II) Ions as a Macroliganted Homogenous Catalyst for Strict Click Reactions of Azides and Alkynes in Water. Journal of Organometallic Chemistry 2019, 898, https://doi.org/10.1016/j.jorganchem.2019.120881.

29. Hrimla, M.; Bahsis, L.; Boutouil, A.; Laamari, M.R.; Julve, M.; Stiriba, S.-E. A Combined Computational and Experimental Study on the Mild Steel Corrosion Inhibition in Hydrochloric Acid by New Multifunctional Phosphonic Acid Containing 1,2,3-Triazoles. Journal of Adhesion Science and Technology 2020, 34, 17411773, https://doi.org/10.1080/01694243.2020.1728177.

30. Chen, Z.; Yan, Q.; Liu, Z.; Xu, Y.; Zhang, Y. Copper-Mediated Synthesis of 1,2,3-Triazoles from NTosylhydrazones and Anilines. Angewandte Chemie International Edition 2013, 52, 13324-13328, https://doi.org/10.1002/anie.201306416. 
31. Alonso, F.; Moglie, Y.; Radivoy, G.; Yus, M. Multicomponent Click Synthesis of 1,2,3-Triazoles from Epoxides in Water Catalyzed by Copper Nanoparticles on Activated Carbon. J. Org. Chem. 2011, 76, 83948405, https://doi.org/10.1021/jo2016339.

32. Ramanjaneyulu, B.T.; Reddy, V.; Arde, P.; Mahesh, S.; Anand, R.V. Combining Oxidative N-Heterocyclic Carbene Catalysis with Click Chemistry: A Facile One-Pot Approach to 1,2,3-Triazole Derivatives. Chemistry - An Asian Journal 2013, 8, 1489-1496, https://doi.org/10.1002/asia.201300138.

33. BIOVIA Studio Modeling Environment Dassault Systèmes BIOVIA; San Diego, 2017.

34. Tochowicz, A.; Maskos, K.; Huber, R.; Oltenfreiter, R.; Dive, V.; Yiotakis, A.; Zanda, M.; Pourmotabbed, T.; Bode, W.; Goettig, P. Crystal Structures of MMP-9 Complexes with Five Inhibitors: Contribution of the Flexible Arg424 Side-Chain to Selectivity. J Mol Biol 2007, 371, 989-1006, https://doi.org/10.1016/j.jmb.2007.05.068.

35. Hu, R.; Barbault, F.; Delamar, M.; Zhang, R. Receptor- and Ligand-Based 3D-QSAR Study for a Series of Non-Nucleoside HIV-1 Reverse Transcriptase Inhibitors. Bioorganic \& Medicinal Chemistry 2009, 17, 2400-2409, https://doi.org/10.1016/j.bmc.2009.02.003.

36. Zarei, A.; Hajipour, A.R.; Khazdooz, L.; Aghaei, H. A Fast and Efficient Method for the Preparation of Aryl Azides Using Stable Aryl Diazonium Silica Sulfates under Mild Conditions. Tetrahedron Letters 2009, 50, 4443-4445, https://doi.org/10.1016/j.tetlet.2009.05.049.

37. Kaushik, C.P.; Kumar, K.; Singh, S.K.; Singh, D.; Saini, S. Synthesis and Antimicrobial Evaluation of 1,4Disubstituted 1,2,3-Triazoles with Aromatic Ester Functionality. Arabian Journal of Chemistry 2016, 9, 865871, https://doi.org/10.1016/j.arabjc.2013.09.023.

38. Bahsis, L.; Ben El Ayouchia, H.; Anane, H.; Triki, S.; Julve, M.; Stiriba, S.-E. Copper(II)-DipicolinateMediated Clickable Azide-Alkyne Cycloaddition in Water as Solvent. Journal of Coordination Chemistry 2018, 71, 633-643, https://doi.org/10.1080/00958972.2018.1435870.

39. Wang, Y.; Liu, J.; Xia, C. Insights into Supported Copper(II)-Catalyzed Azide-Alkyne Cycloaddition in Water. Advanced Synthesis \& Catalysis 2011, 353, 1534-1542, https://doi.org/10.1002/adsc.201000868.

40. Kuang, G.-C.; Michaels, H.A.; Simmons, J.T.; Clark, R.J.; Zhu, L. Chelation-Assisted, Copper(II)-AcetateAccelerated Azide-Alkyne Cycloaddition. J. Org. Chem. 2010, 75, 6540-6548, https://doi.org/10.1021/jo101305m.

41. Gupta, S.; Kass, G.E.; Szegezdi, E.; Joseph, B. The Mitochondrial Death Pathway: A Promising Therapeutic Target in Diseases. J Cell Mol Med 2009, 13, 1004-1033, https://doi.org/10.1111/j.1582-4934.2009.00697.x.

42. Ma, N.; Wang, Y.; Zhao, B.-X.; Ye, W.-C.; Jiang, S. The Application of Click Chemistry in the Synthesis of Agents with Anticancer Activity. Drug Des Devel Ther 2015, 9, 1585-1599, https://doi.org/10.2147/dddt.s56038.

43. Cohen, J.J. Apoptosis. Immunology Today 1993, 14, 126-130, https://doi.org/10.1016/0167-5699(93)902146.

44. Hengartner, M.O. The Biochemistry of Apoptosis. Nature 2000, 407, 770-776, https://doi.org/10.1038/35037710.

45. Ghaleb, A.; Aouidate, A.; Bouachrine, M.; Lakhlifi, T.; Sbai, A. In Silico Exploration of Aryl Halides Analogues as Checkpoint Kinase 1 Inhibitors by Using 3D QSAR, Molecular Docking Study, and ADMET Screening. Adv Pharm Bull 2019, 9, 84-92, https://doi.org/10.15171/apb.2019.011. 


\section{Supplementary Materials}

${ }^{1} \mathrm{H},{ }^{13} \mathrm{C}$ NMR, FTIR and HRMS spectra of 1,2,3-triazole derivatives 7-10 were assigned as reported in previously published studies.
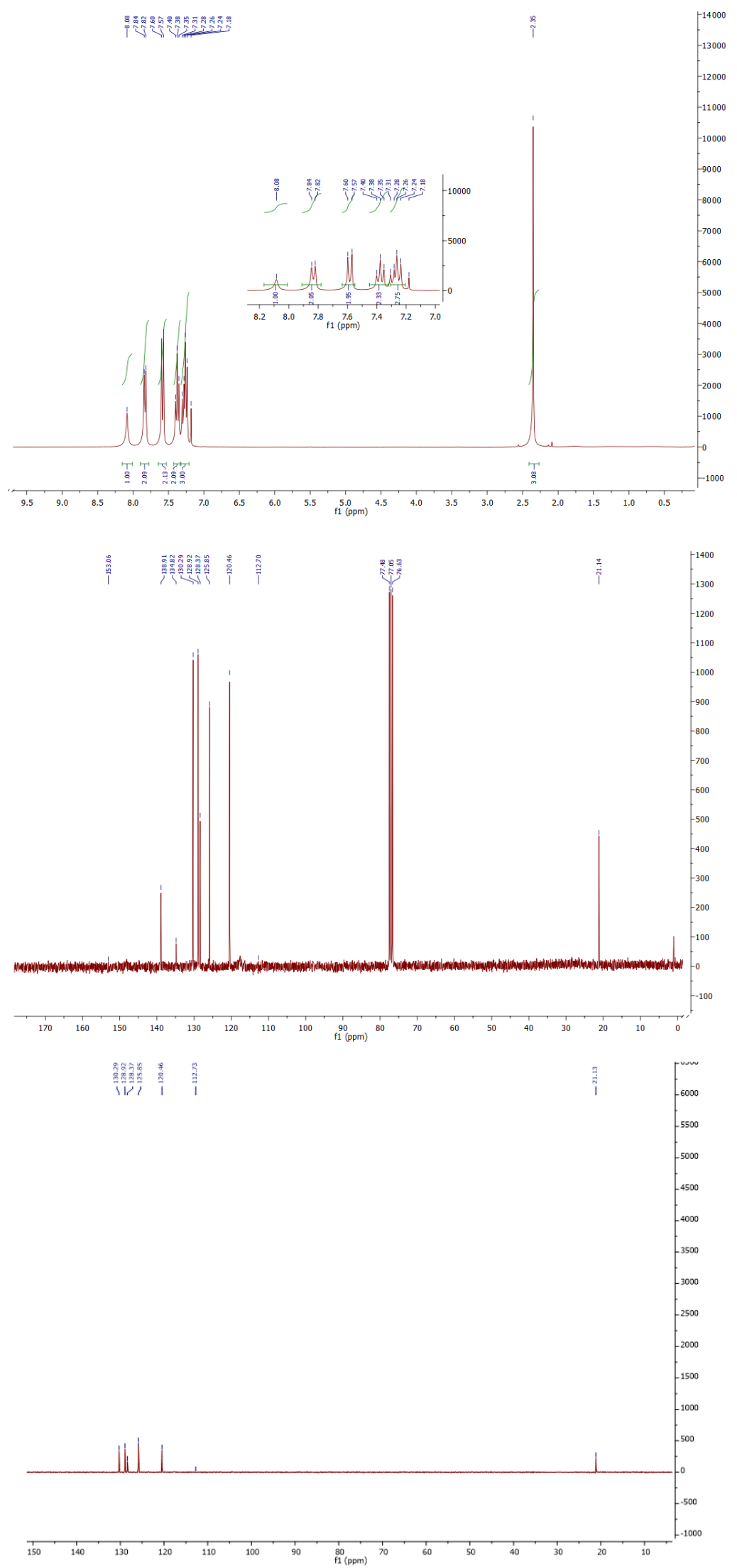

Figure S1. The spectrums NMR proton, Carbone, and Dept 135 of Product 1. 


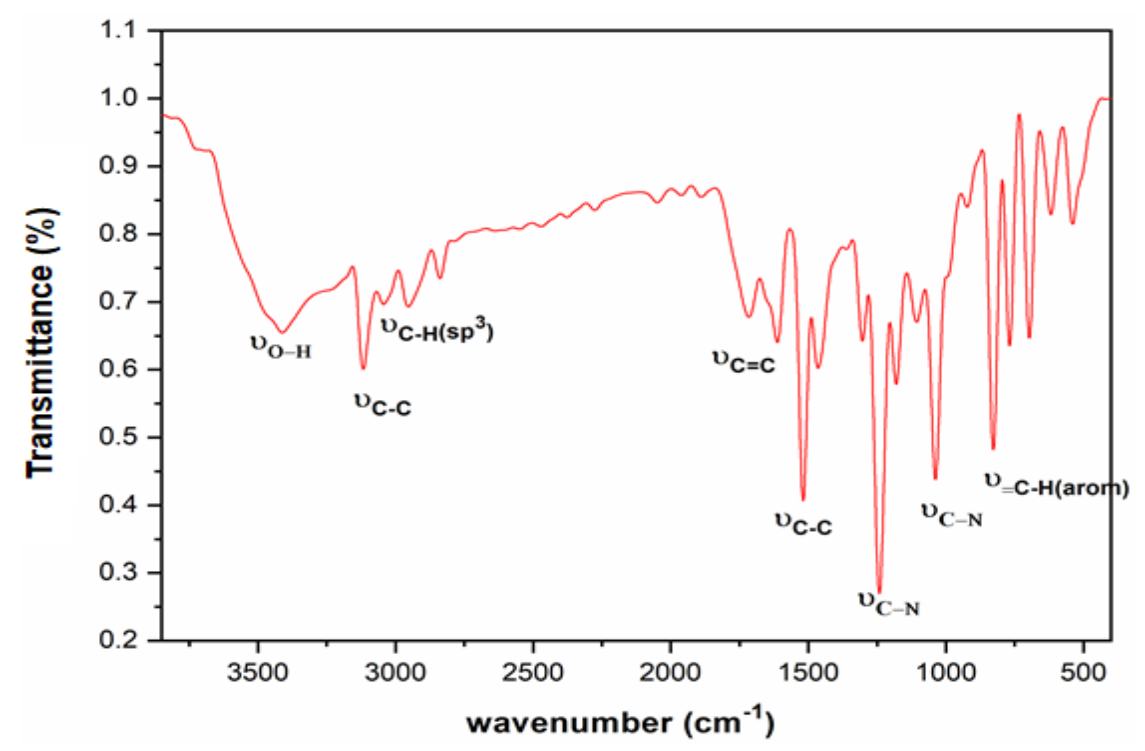

Figure S2. FT-IR absorption spectrum of Product 1.

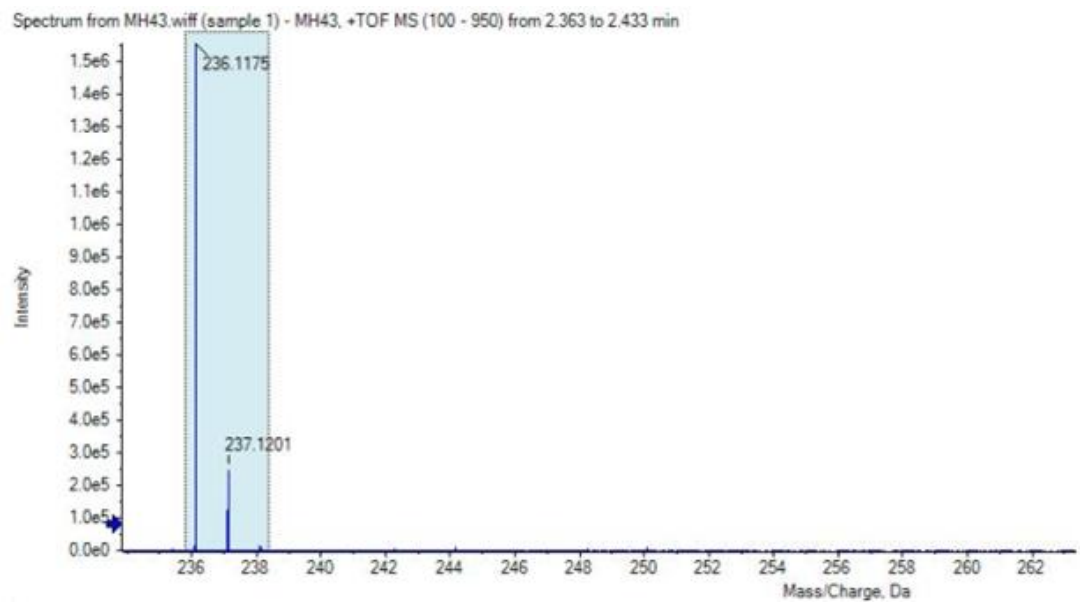

Figure S3. The spectrum HRMS of Product 1.

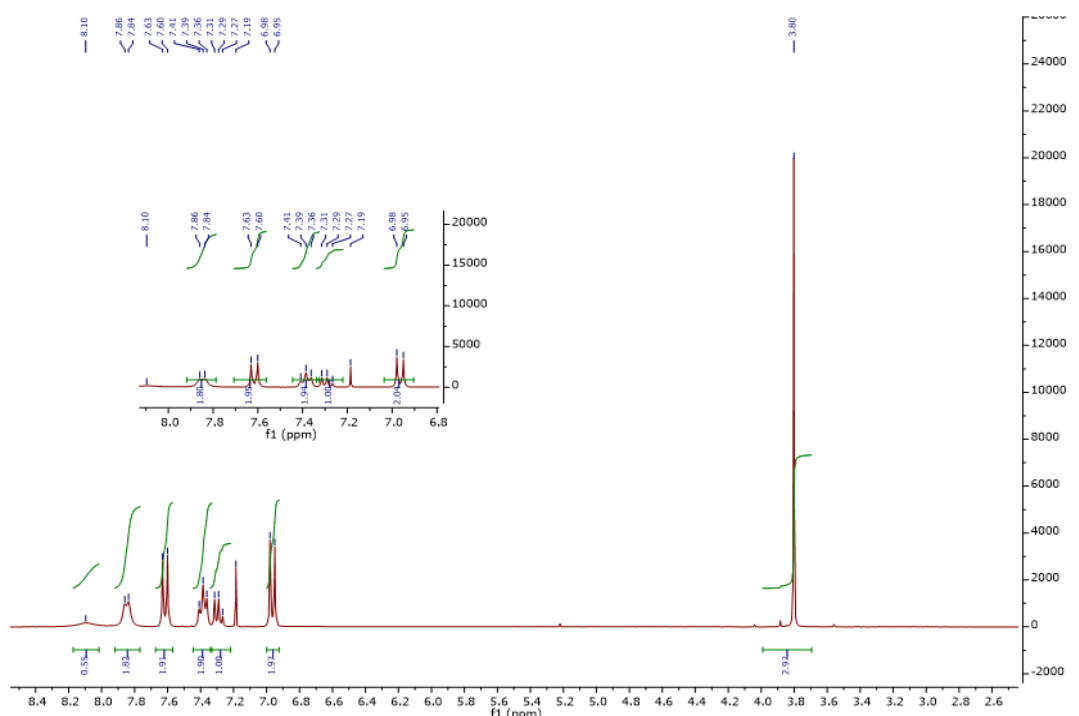




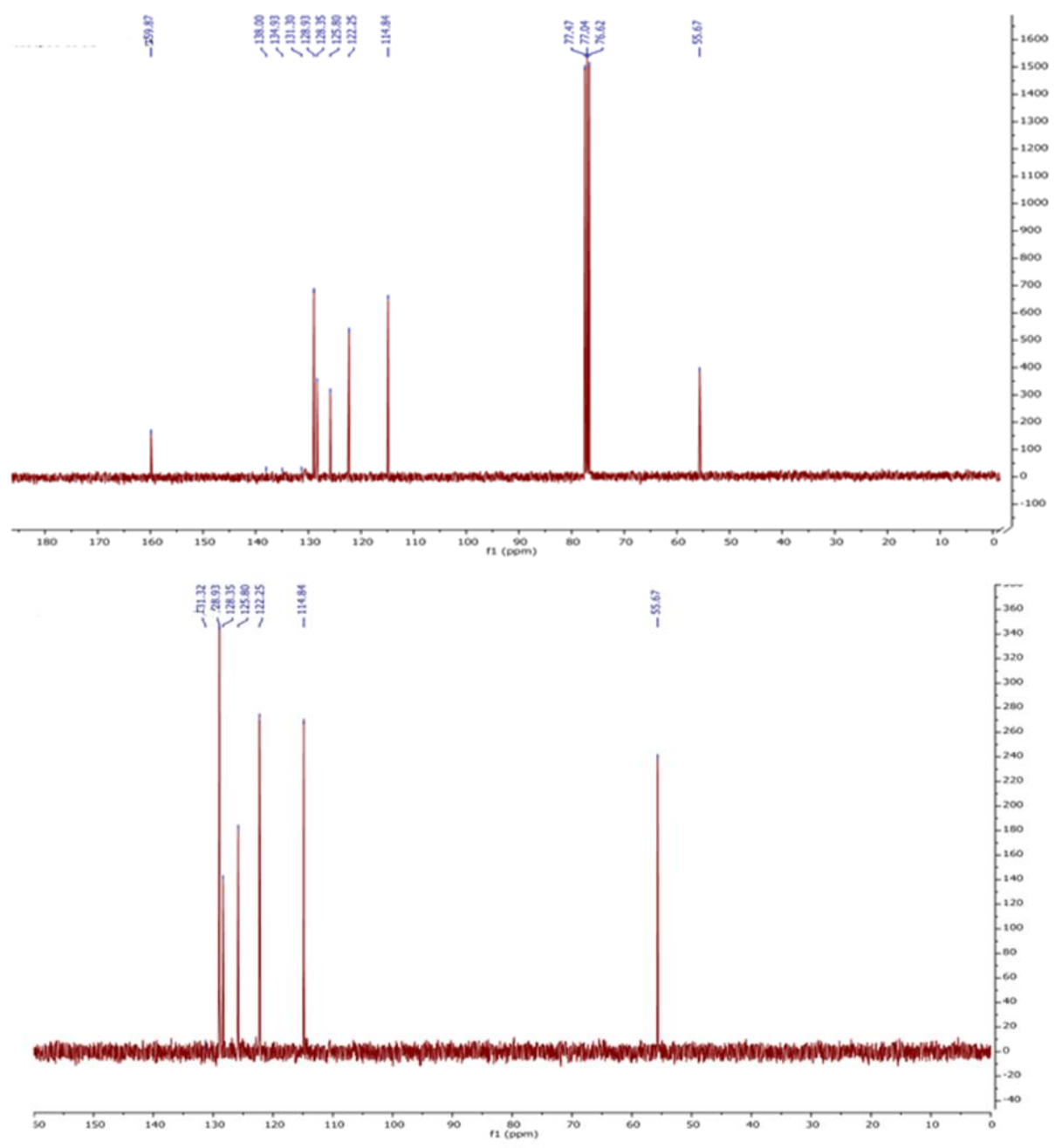

Figure S4. The spectrums NMR proton, Carbone, and Dept 135 of Product 2.

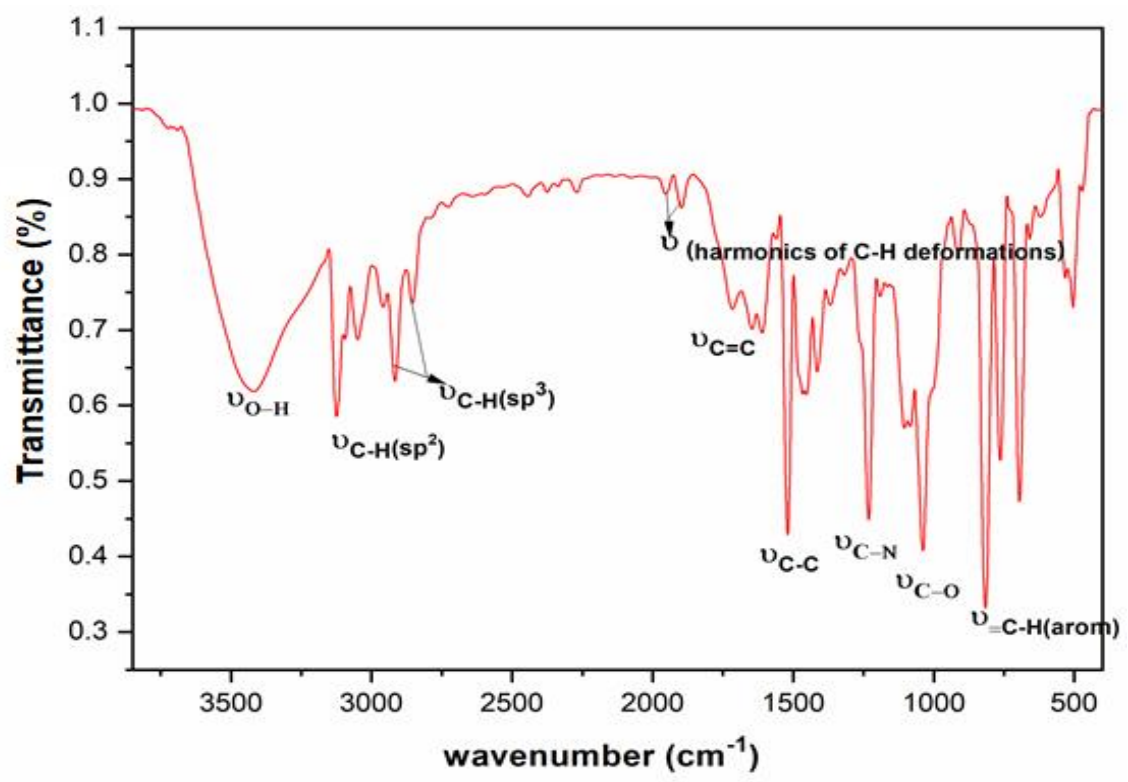

Figure S5. FT-IR absorption spectrum of Product 2. 


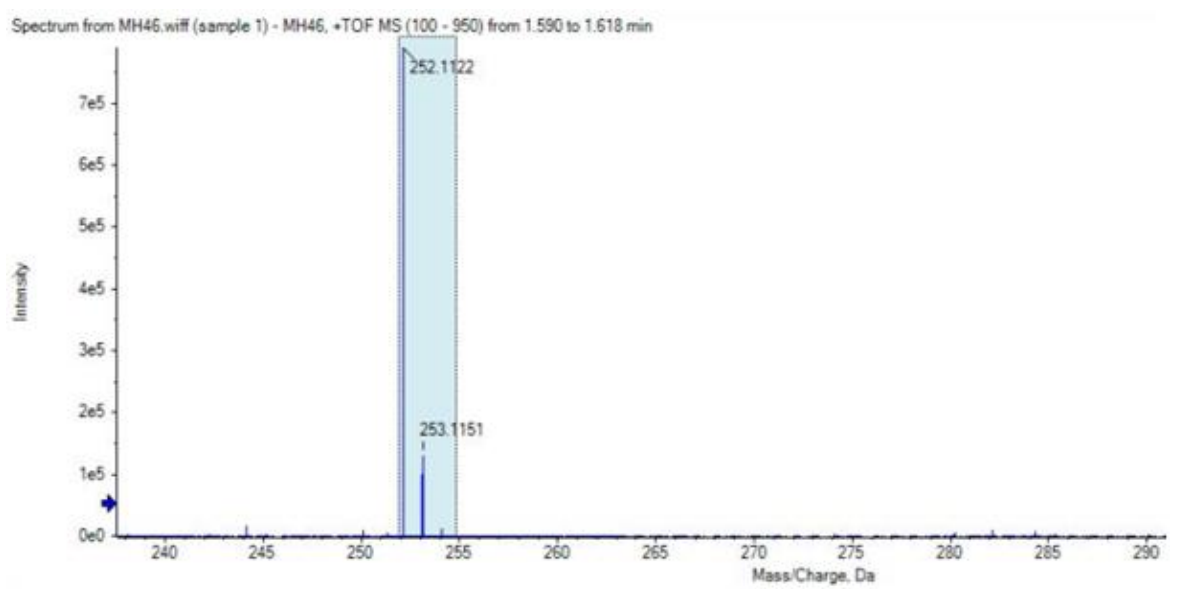

Figure S6. The spectrum HRMS of Product 2.

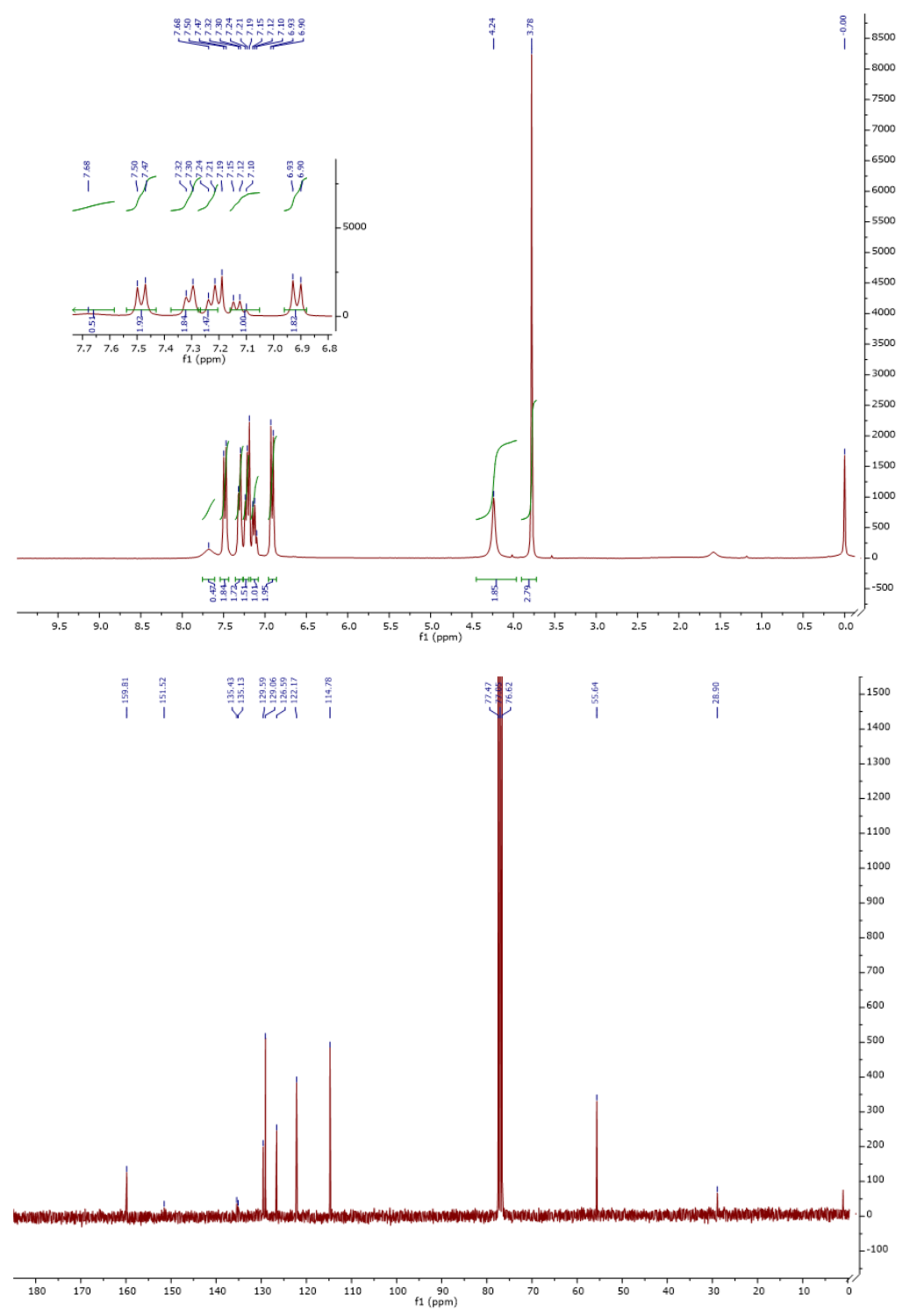




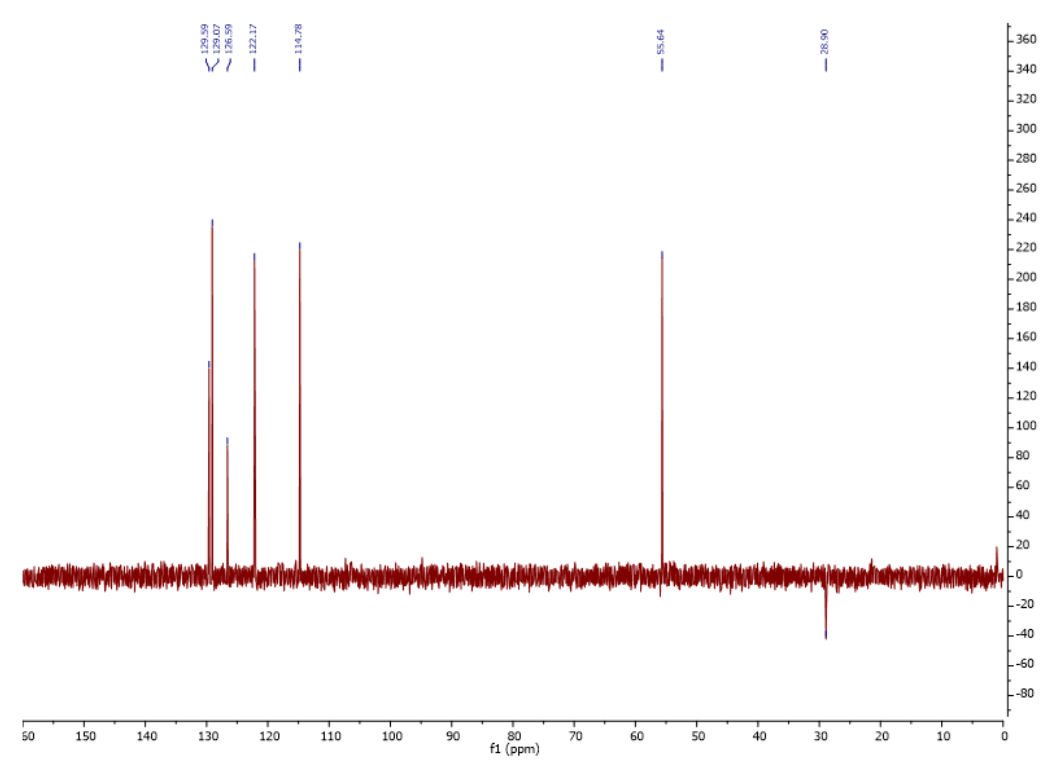

Figure S7. The spectrums NMR proton, Carbone, and Dept 135 of Product 3.

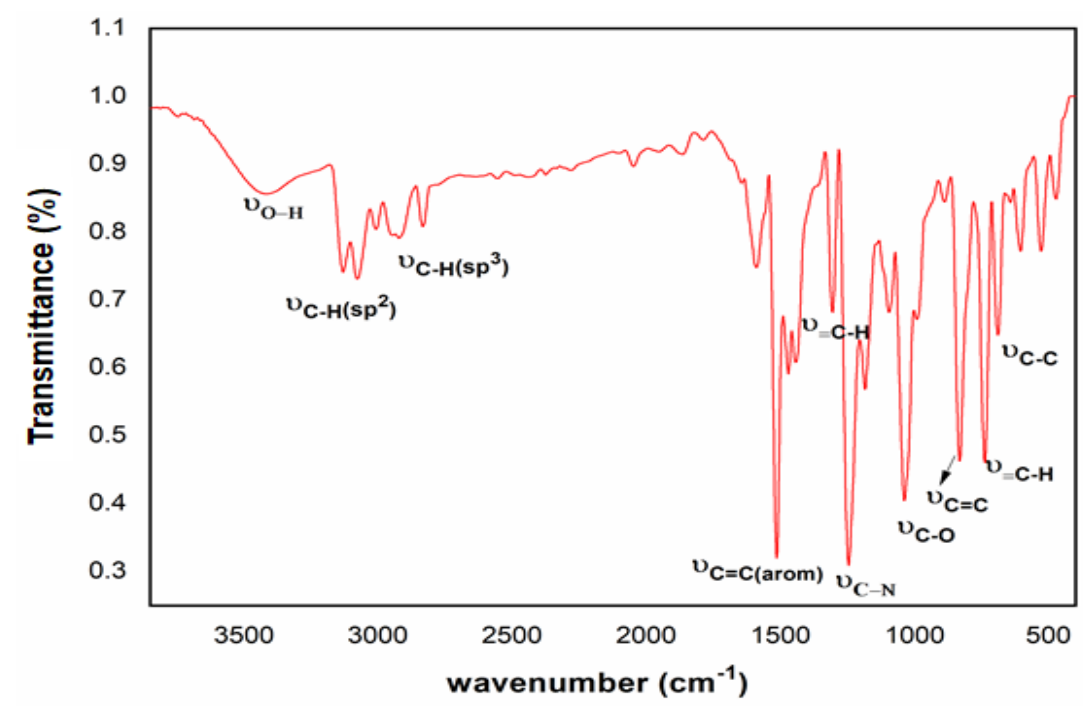

Figure S8. FT-IR absorption spectrum of Product 3.

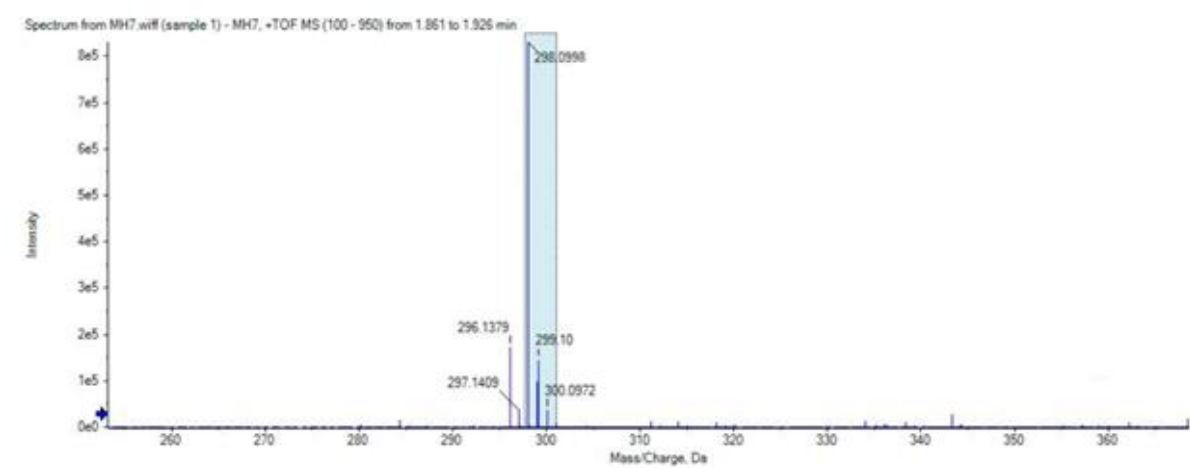

Figure S9. The spectrum HRMS of Product 3. 

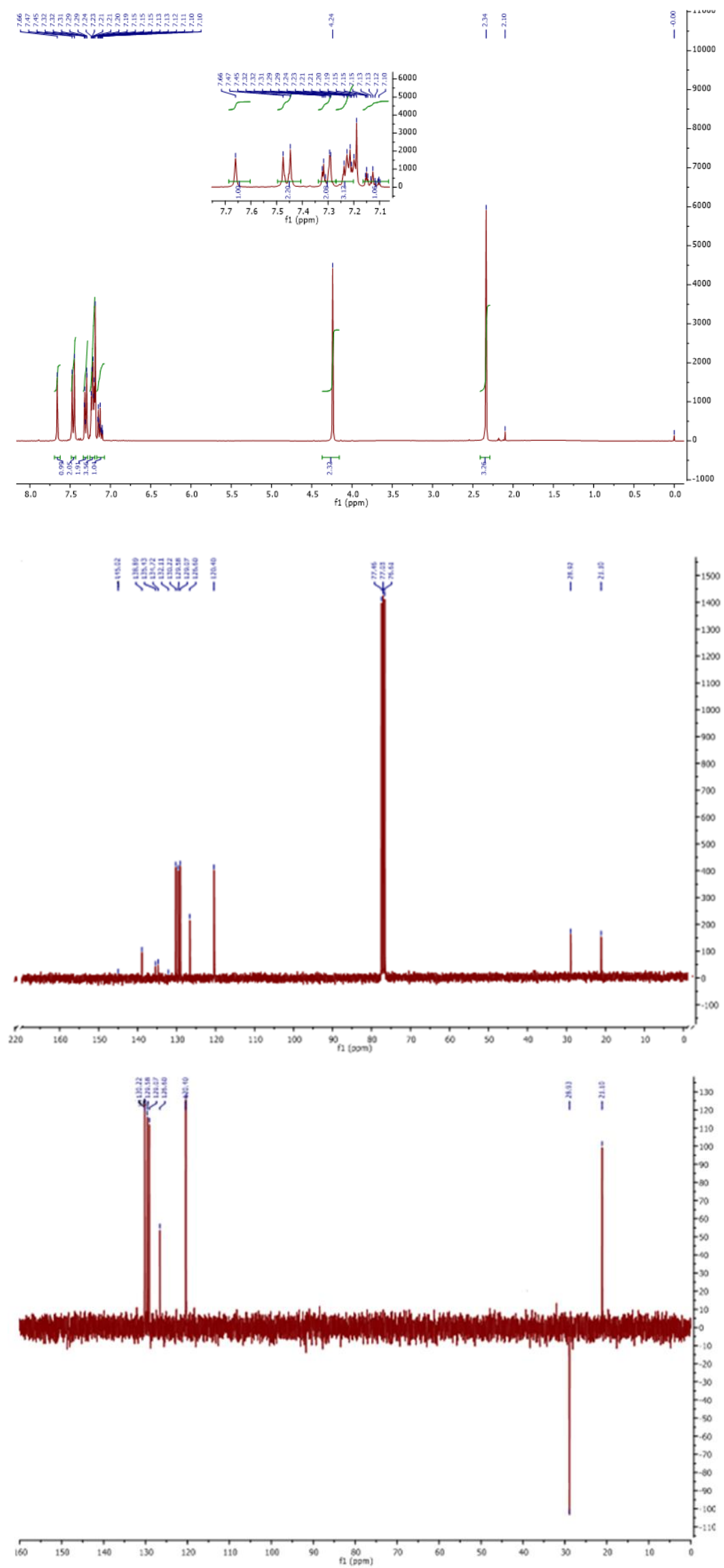

Figure S10. The spectrums NMR proton, Carbone, and Dept 135 of Product 4. 


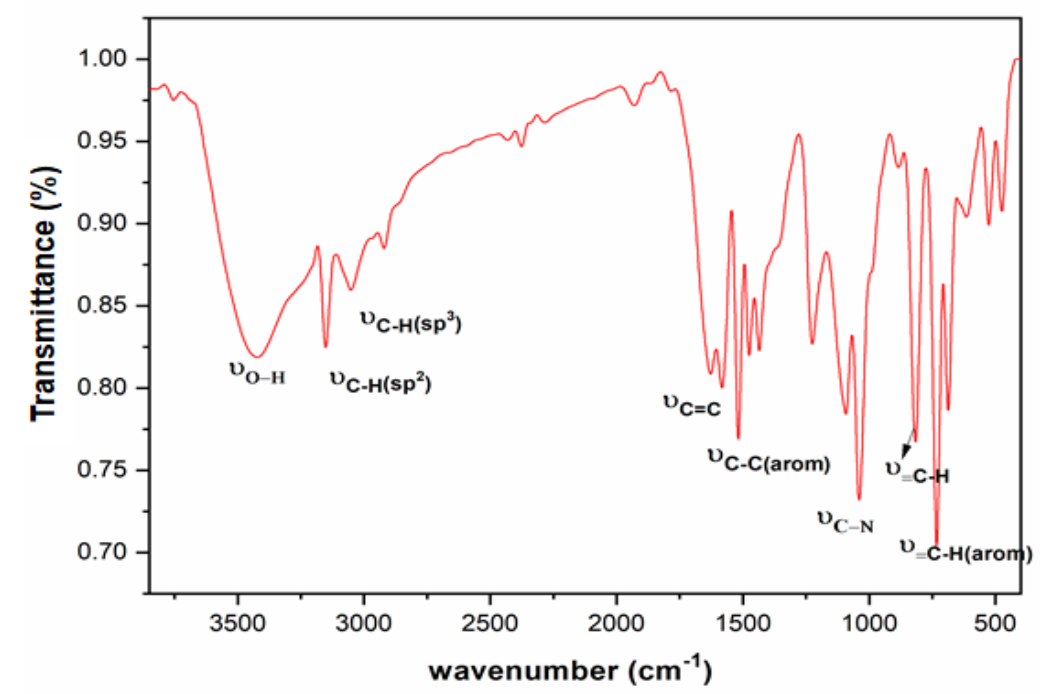

Figure S11. FT-IR absorption spectrum of Product 4.

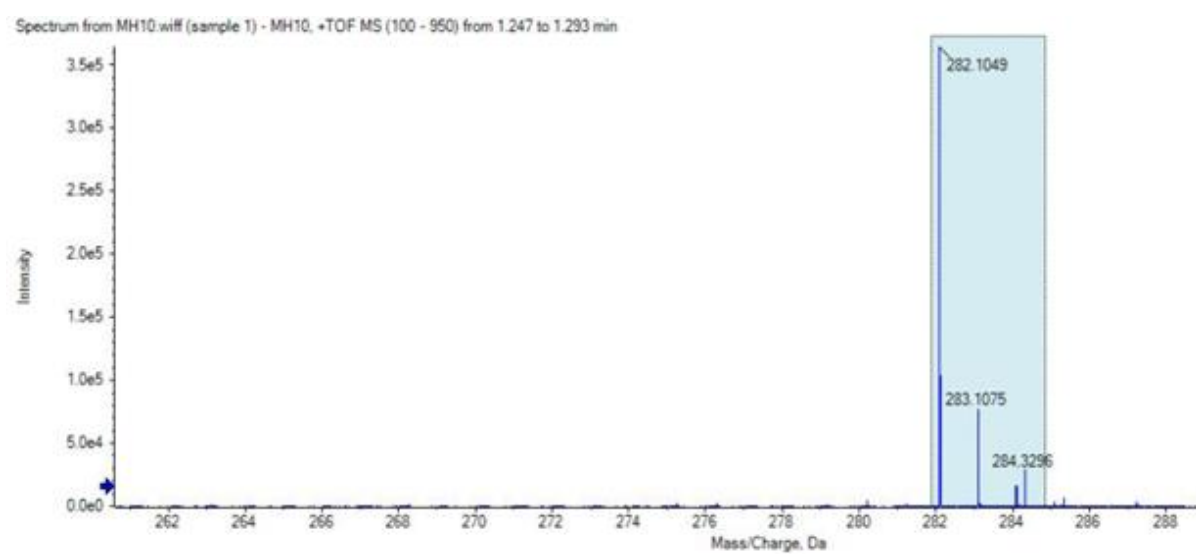

Figure S12. The spectrum HRMS of Product 4.

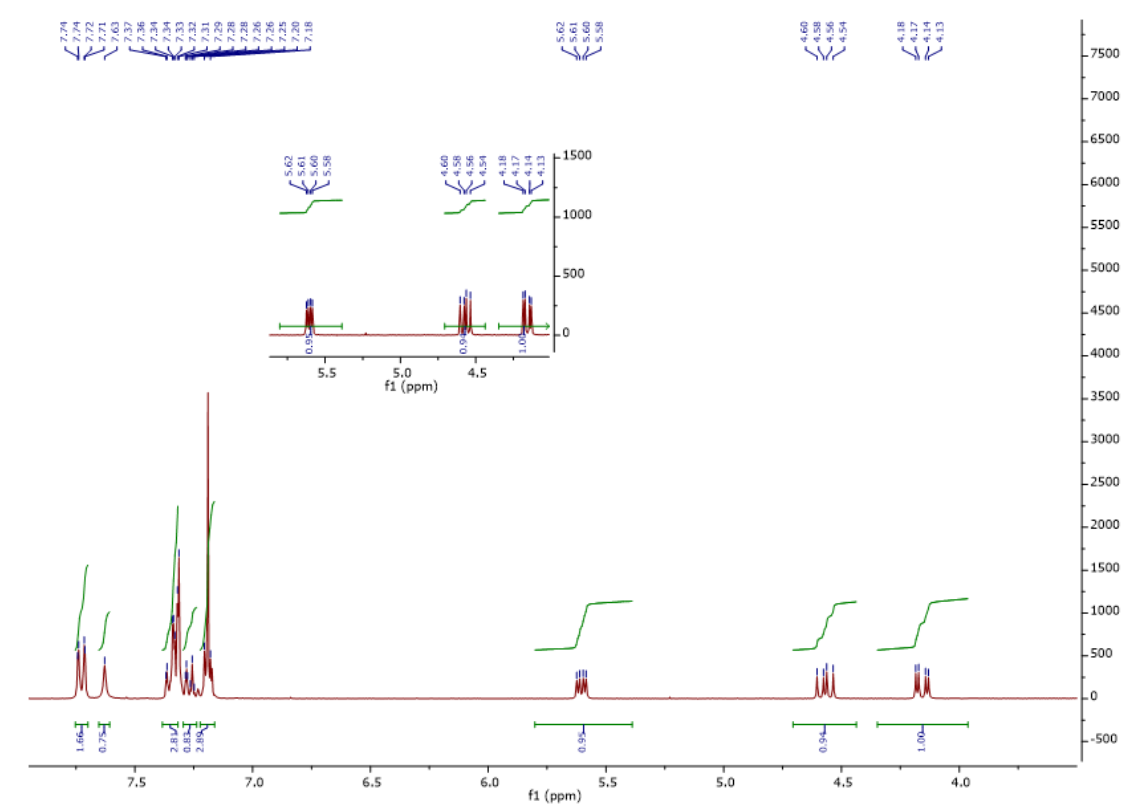



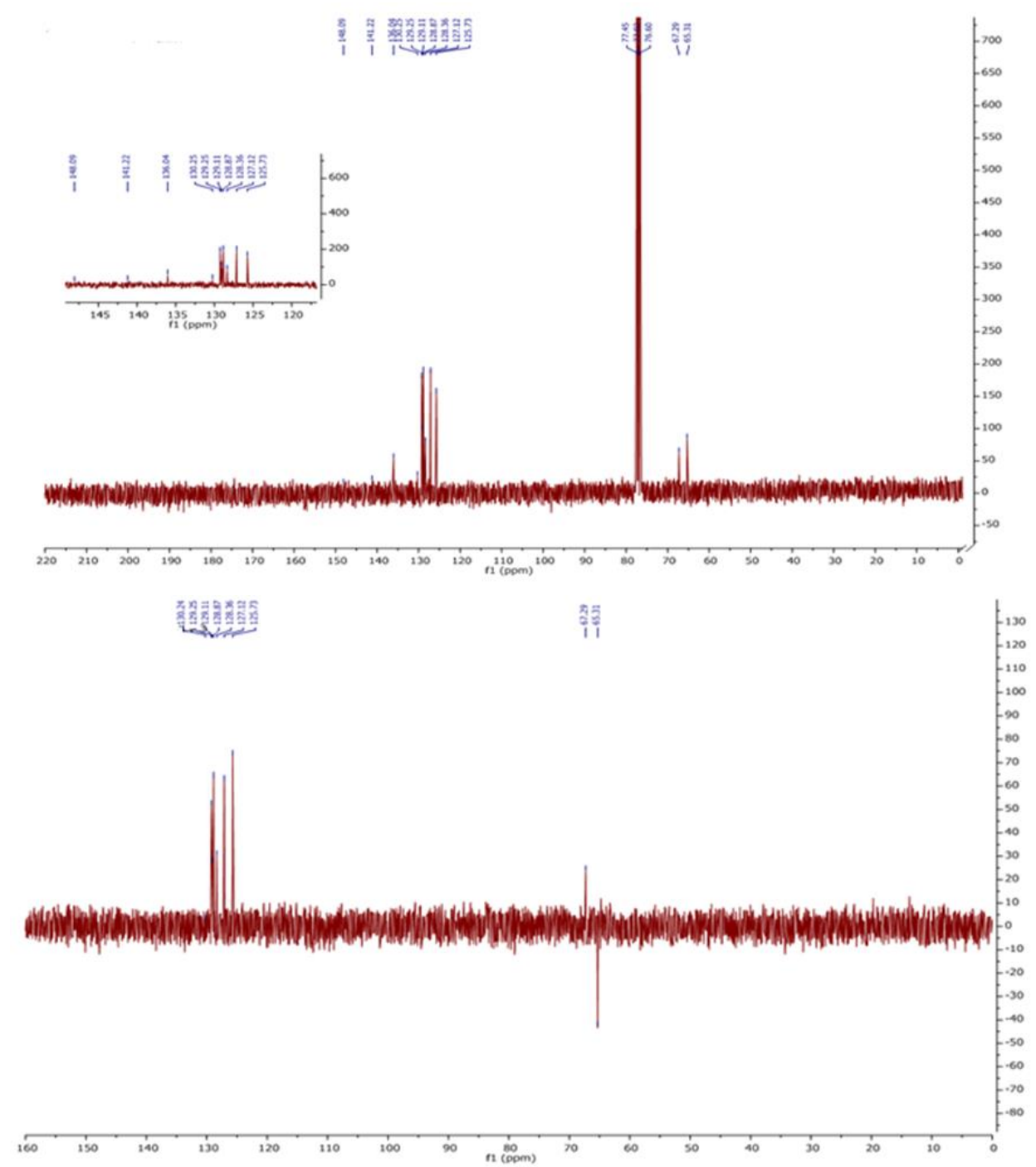

Figure S13. The spectrums NMR proton, Carbone, and Dept 135 of Product 5.

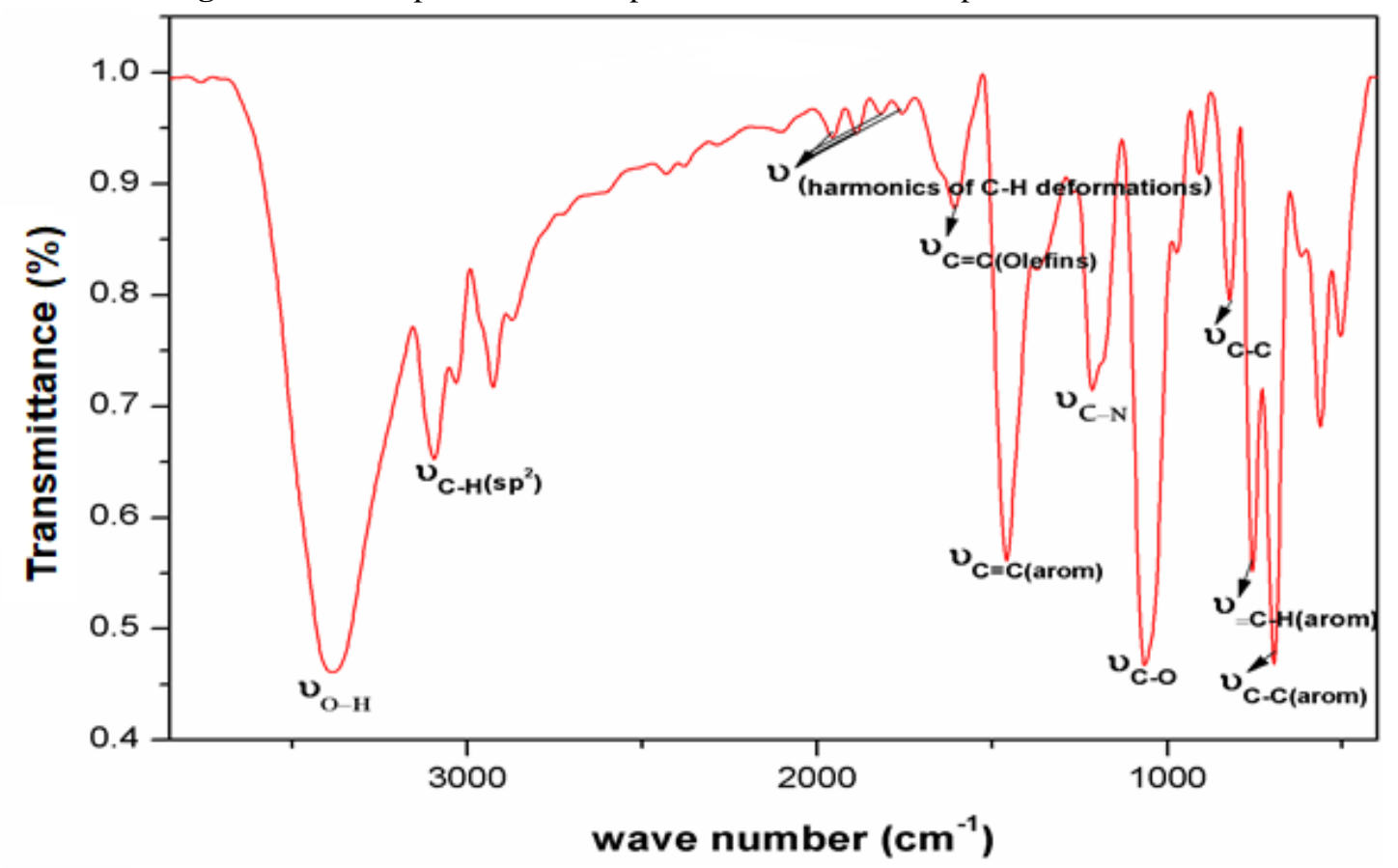

Figure S14. FT-IR absorption spectrum of Product 5. 


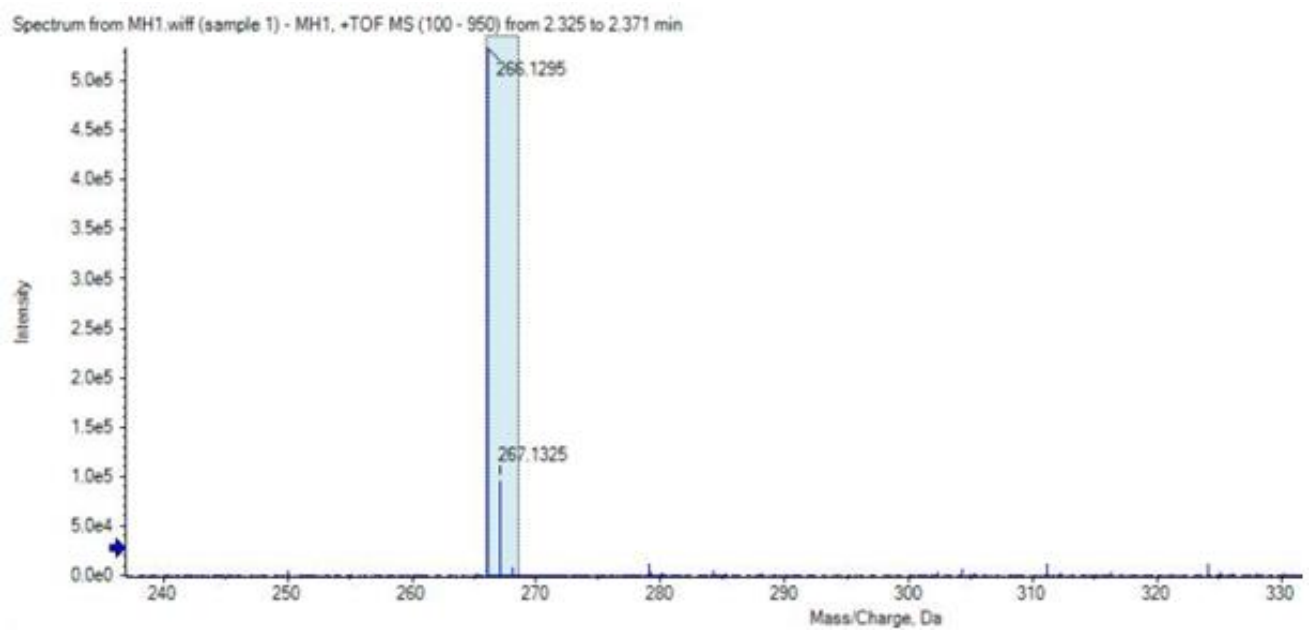

Figure S15. The spectrum HRMS of Product 5.
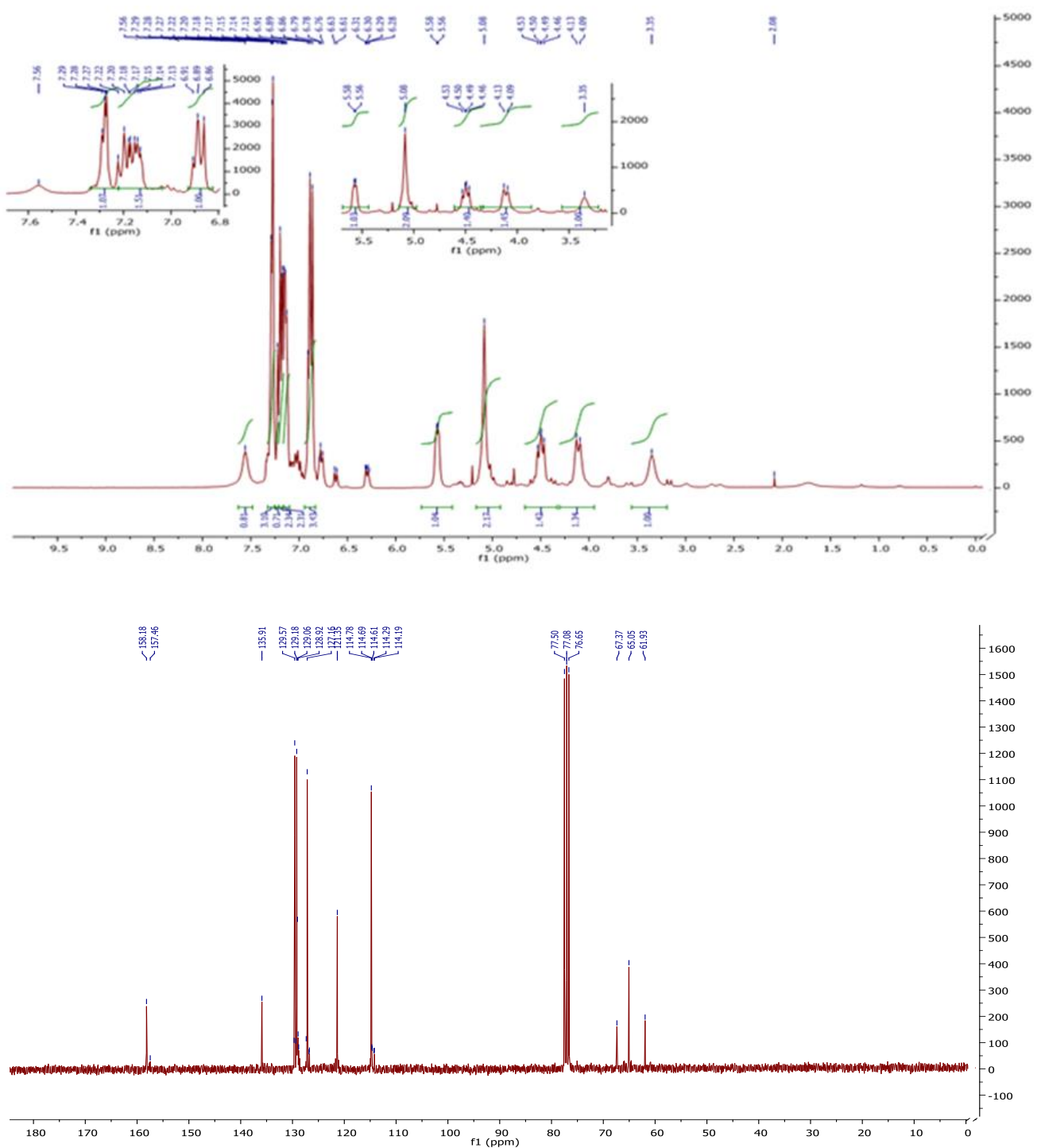


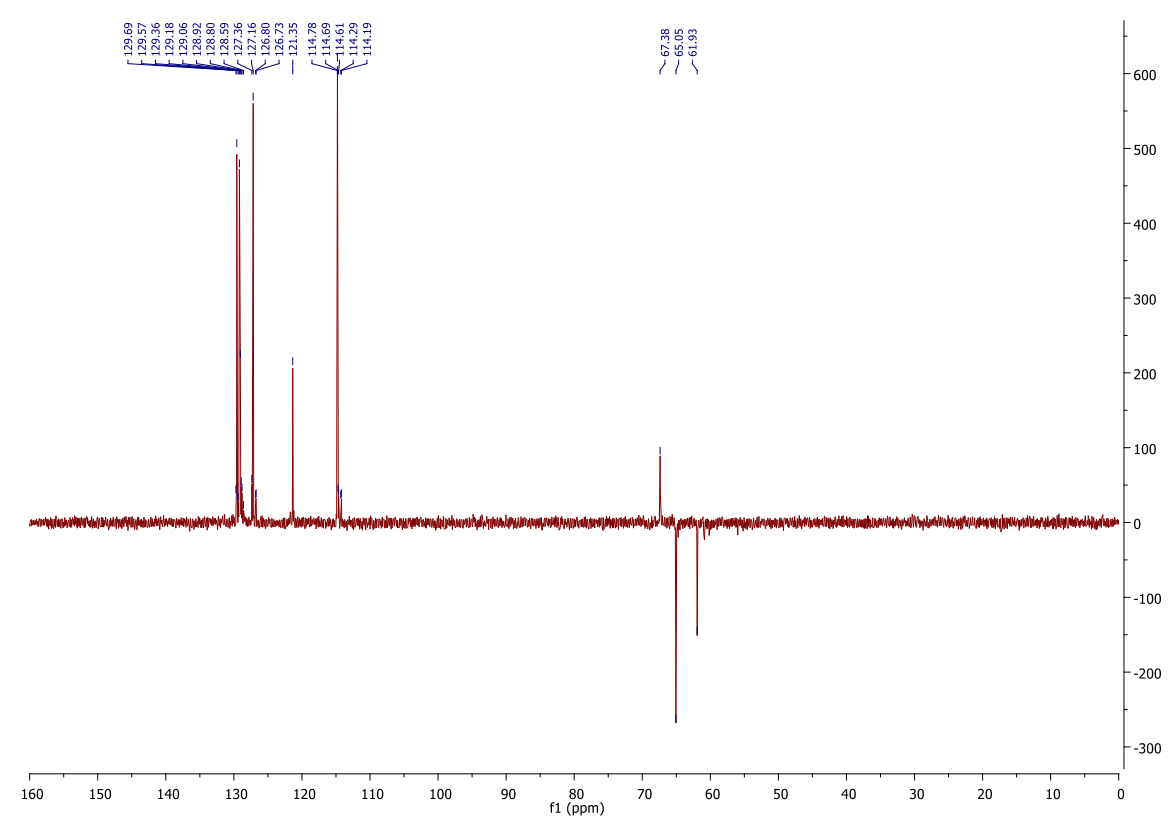

Figure S16. The spectrums NMR proton, Carbone, and Dept 135 of Product 6.

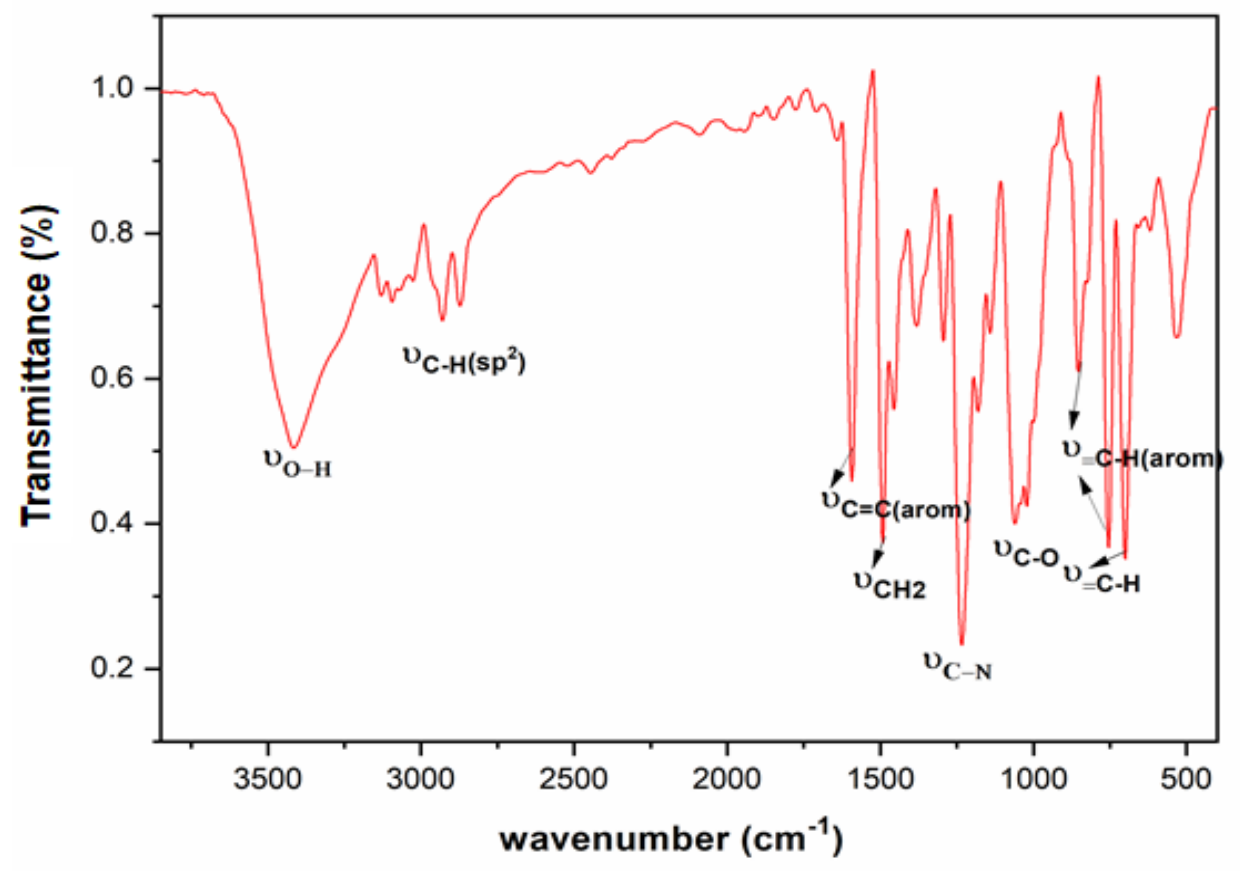

Figure S17. FT-IR absorption spectrum of Product 6.

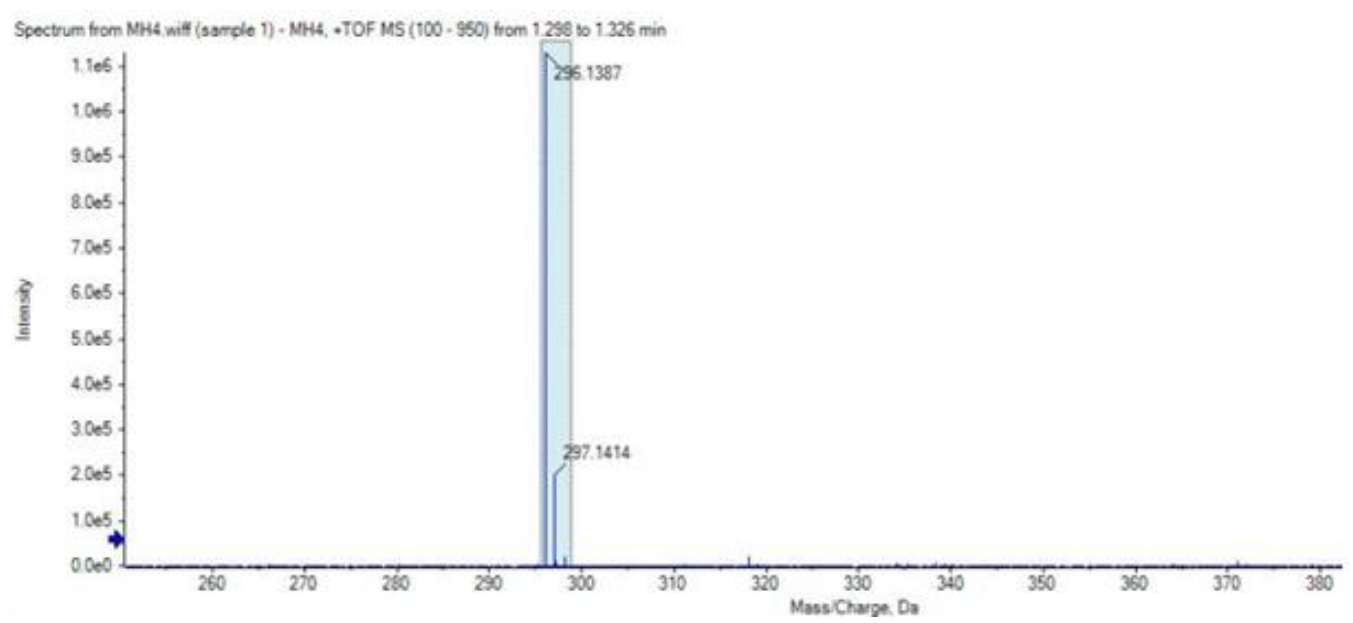

Figure S18. The spectrum HRMS of Product 6. 

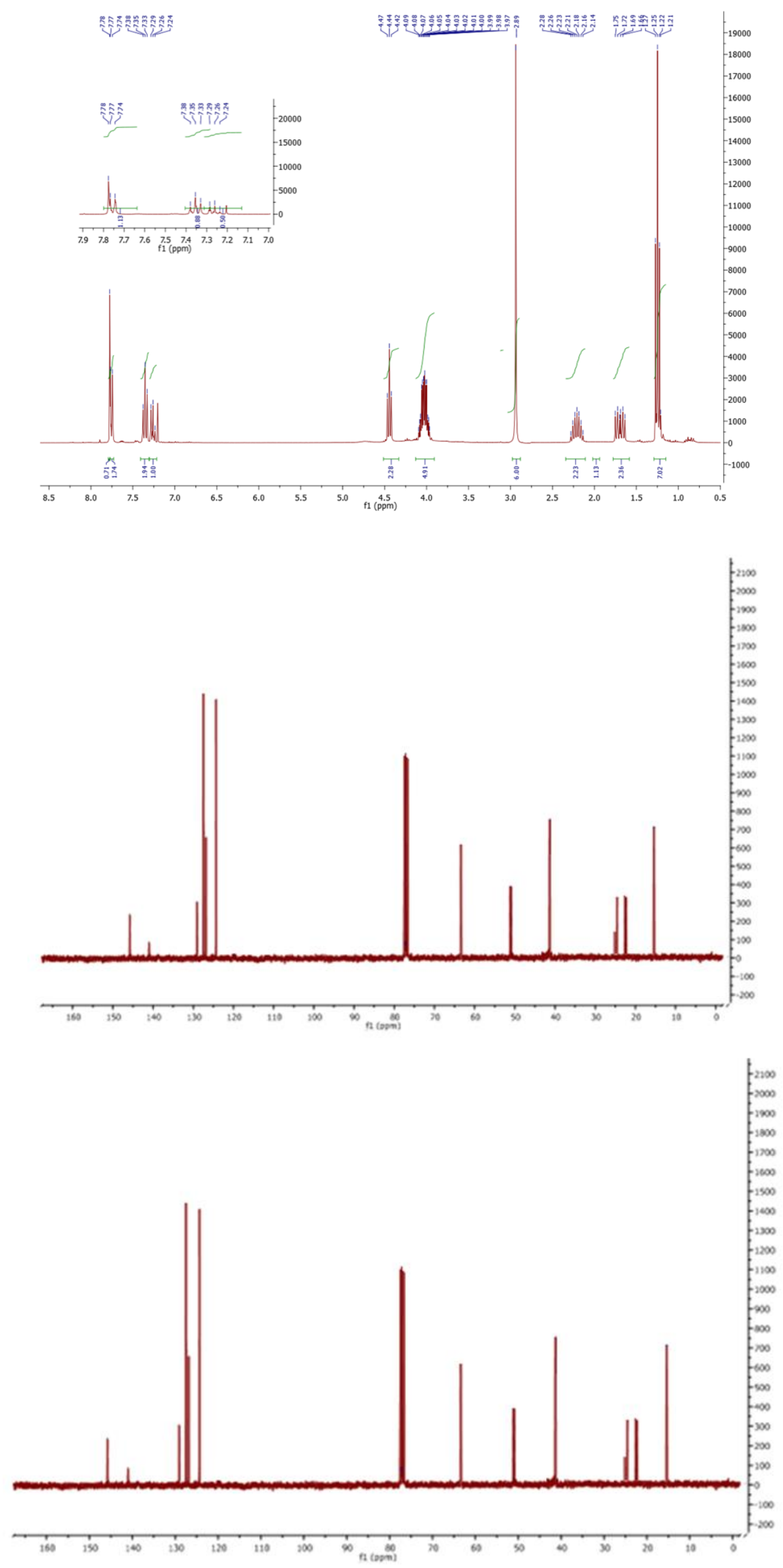

Figure S19. The spectrums NMR proton, Carbone, and Dept 135 of Product 7. 


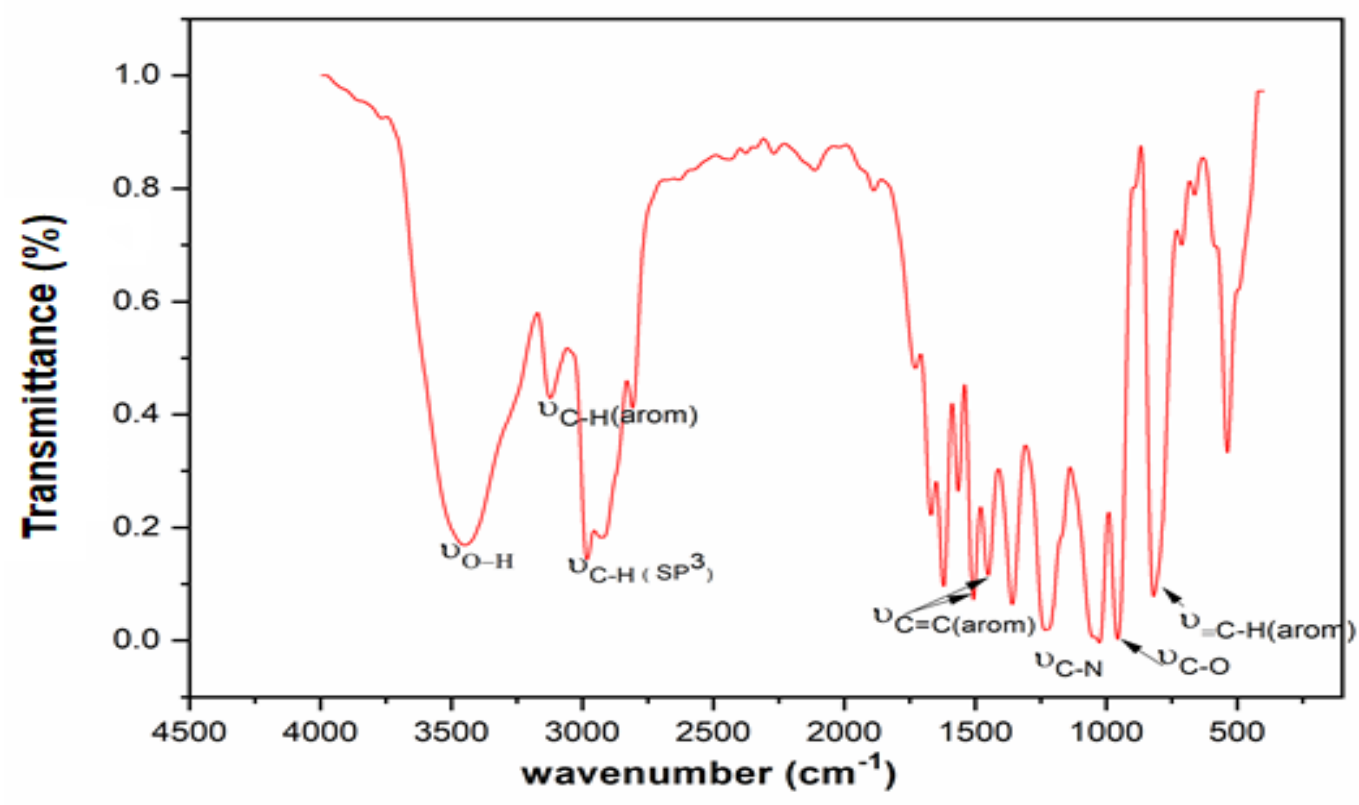

Figure S20. FT-IR absorption spectrum of Product 7.

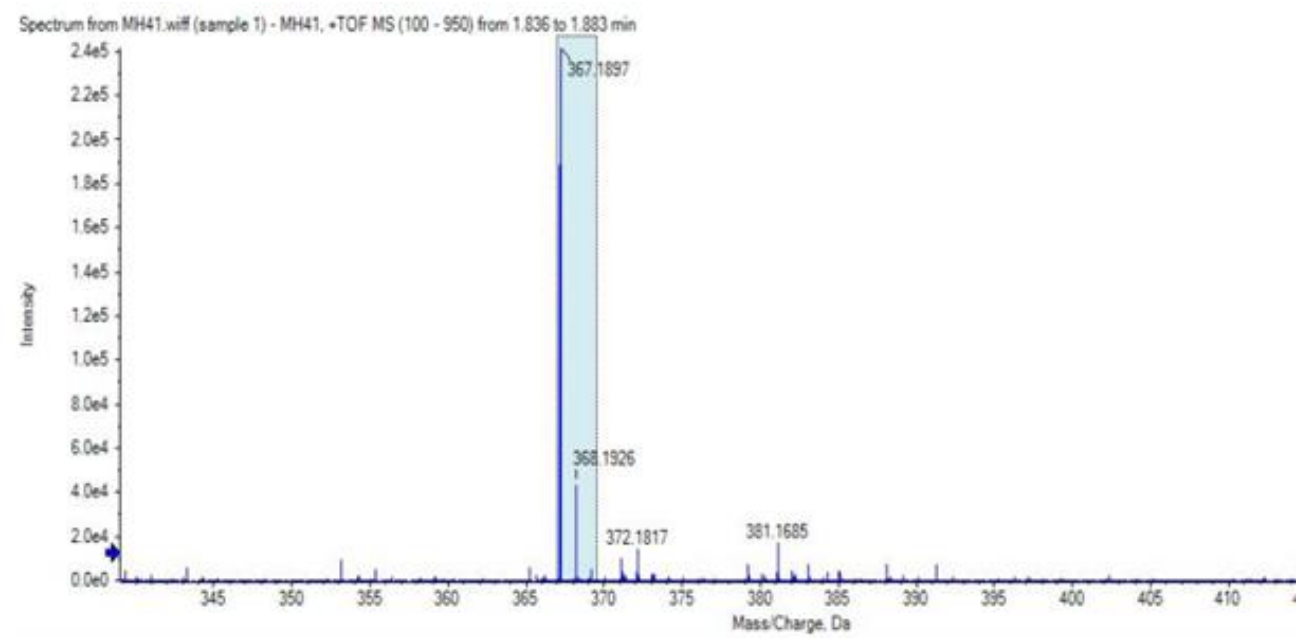

Figure S21. The spectrum HRMS of Product 7.

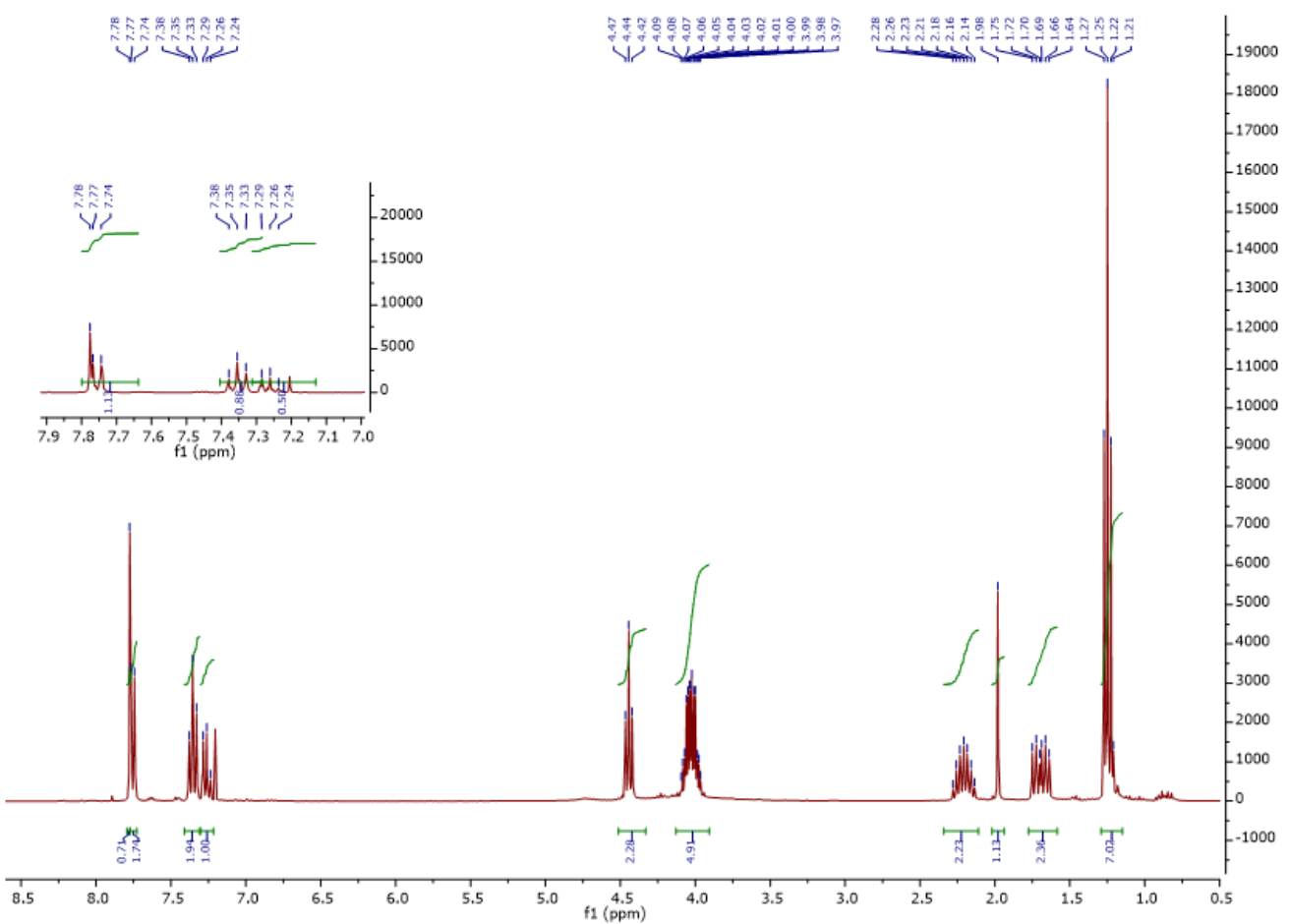




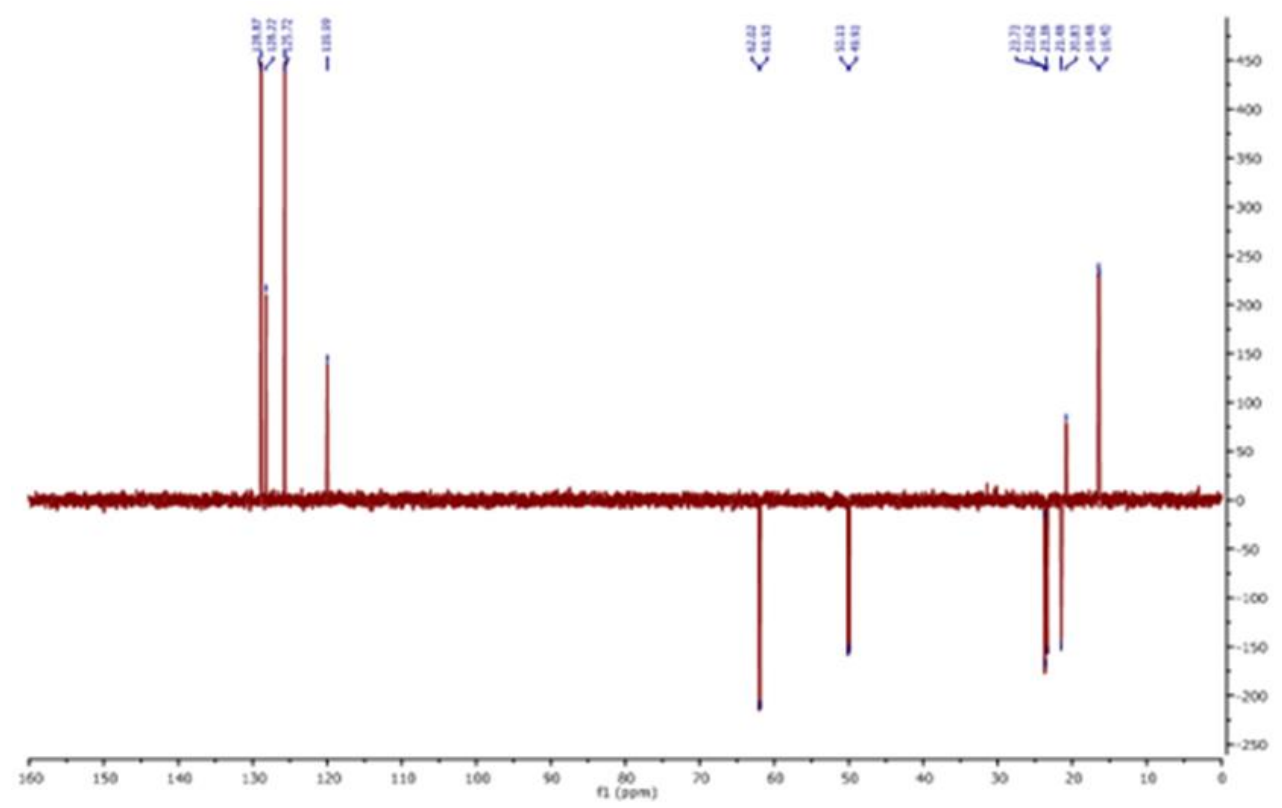

Figure S22. The spectrums NMR proton, and Dept 135 of Product 8.

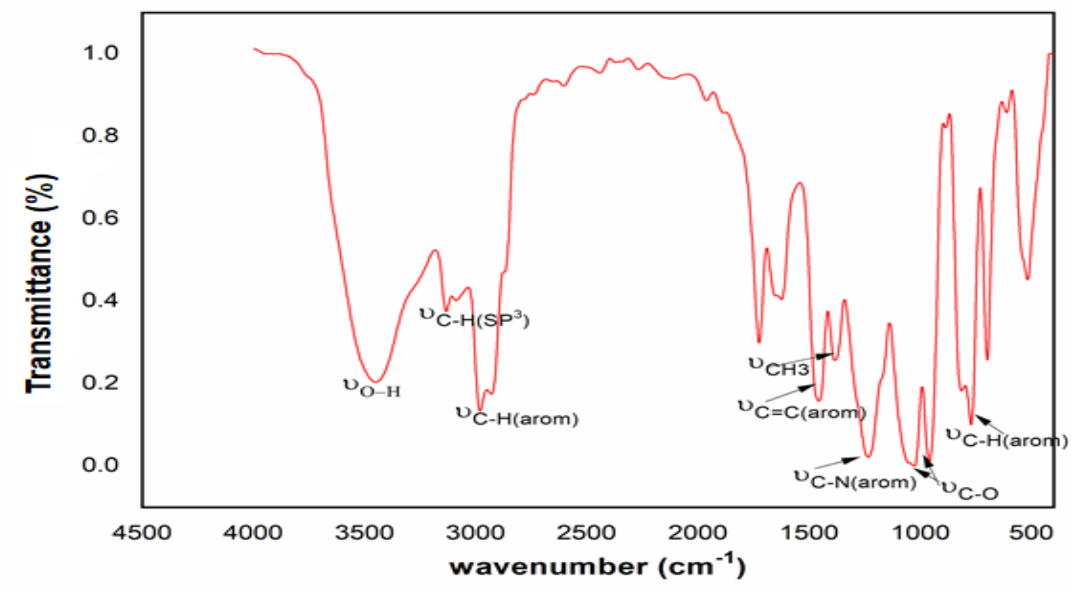

Figure S23. FT-IR absorption spectrum of Product 8 .

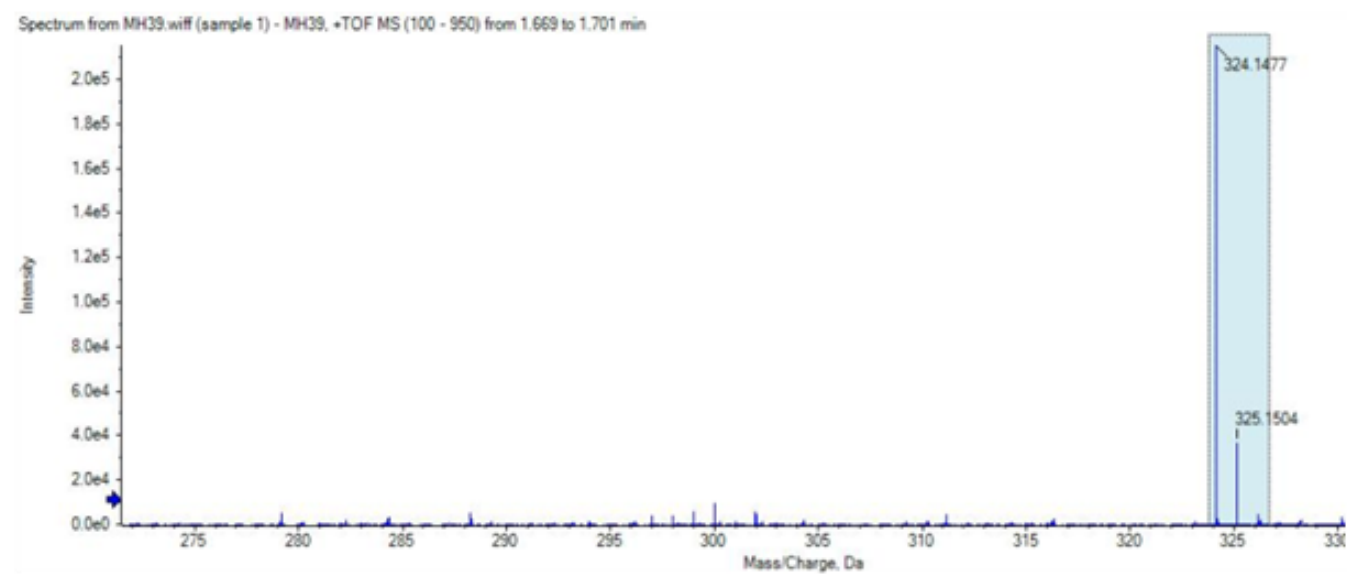

Figure S24. The spectrum HRMS of Product 8. 

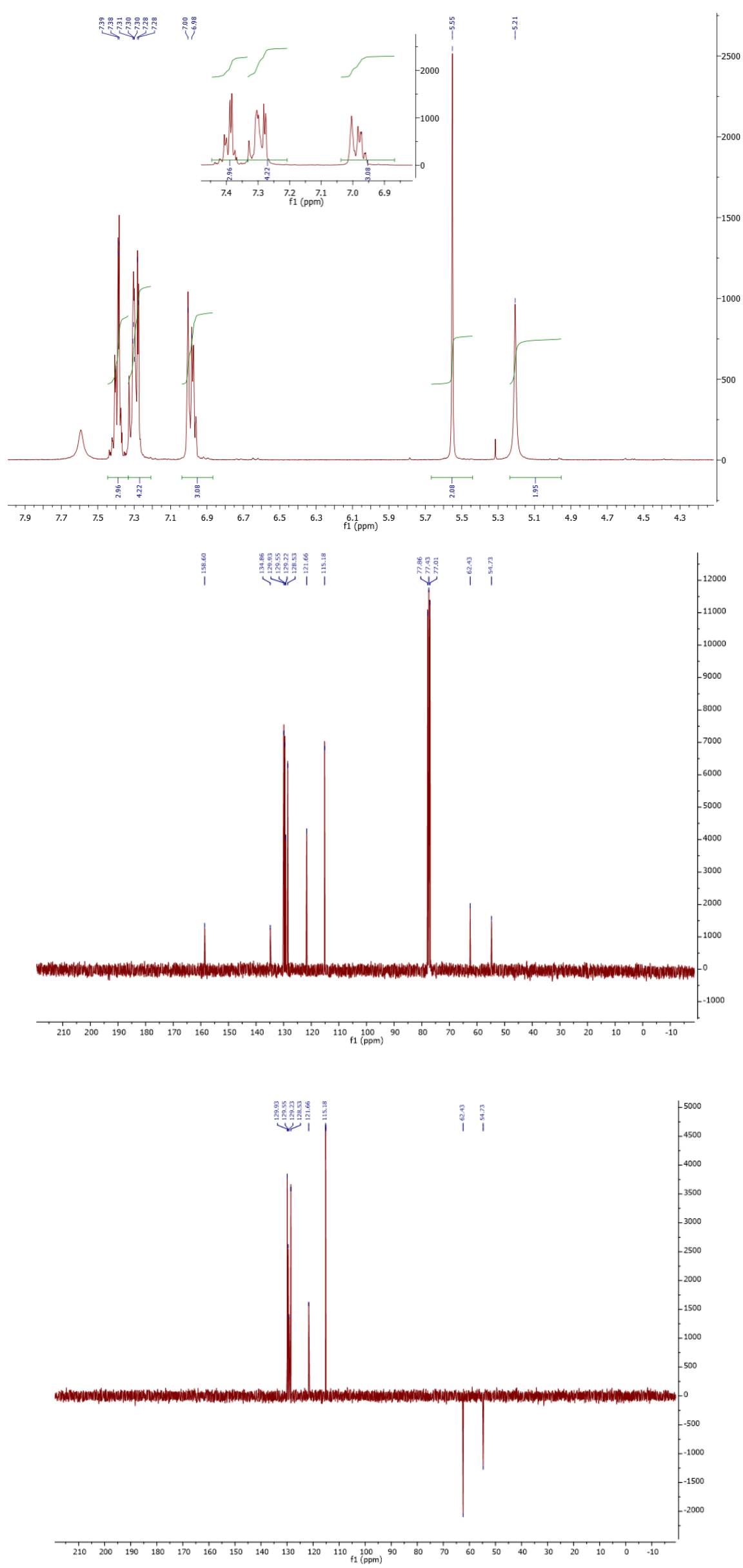

Figure S25. The spectrums NMR proton, Carbone, and Dept 135 of Product 9. 


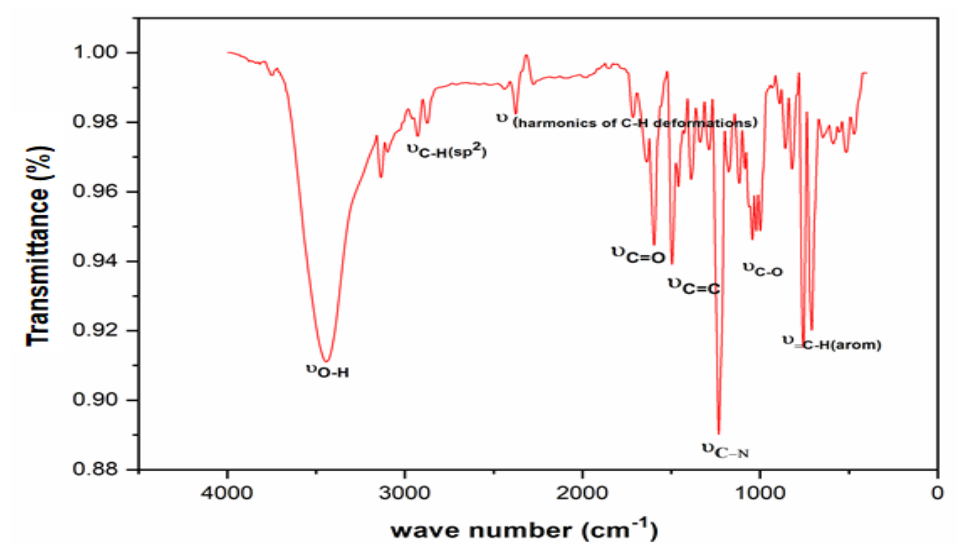

Figure S26. FT-IR absorption spectrum of Product 9.

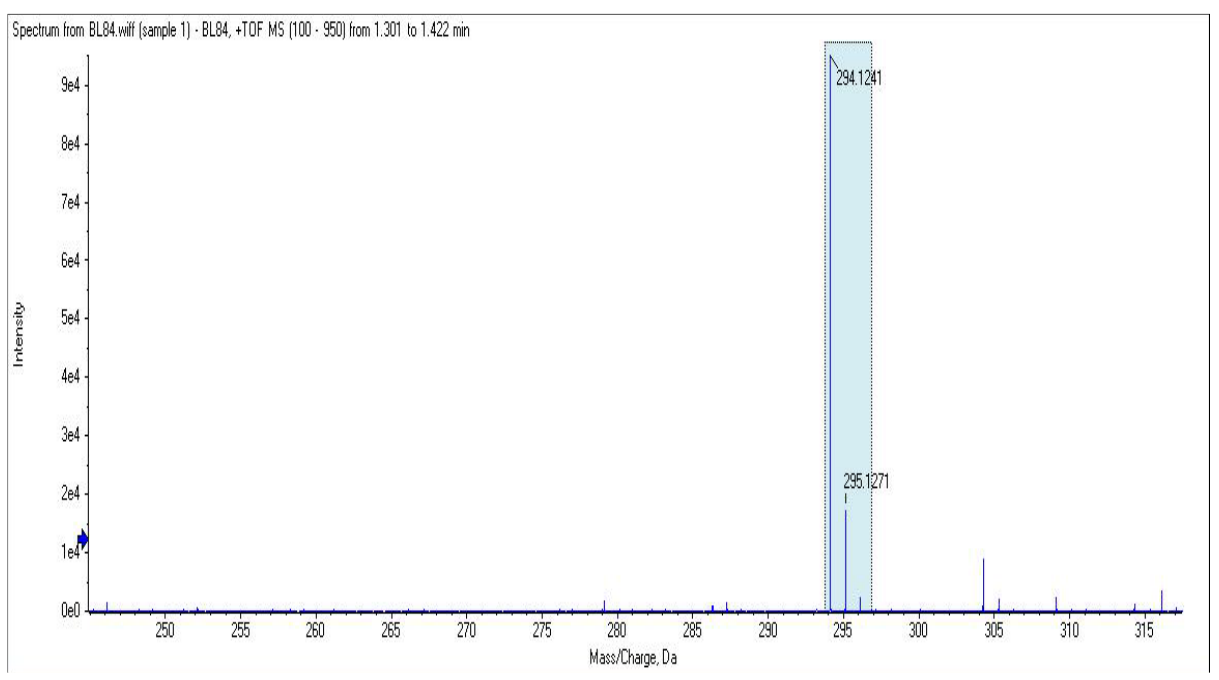

Figure S27. The spectrum HRMS of Product 9.

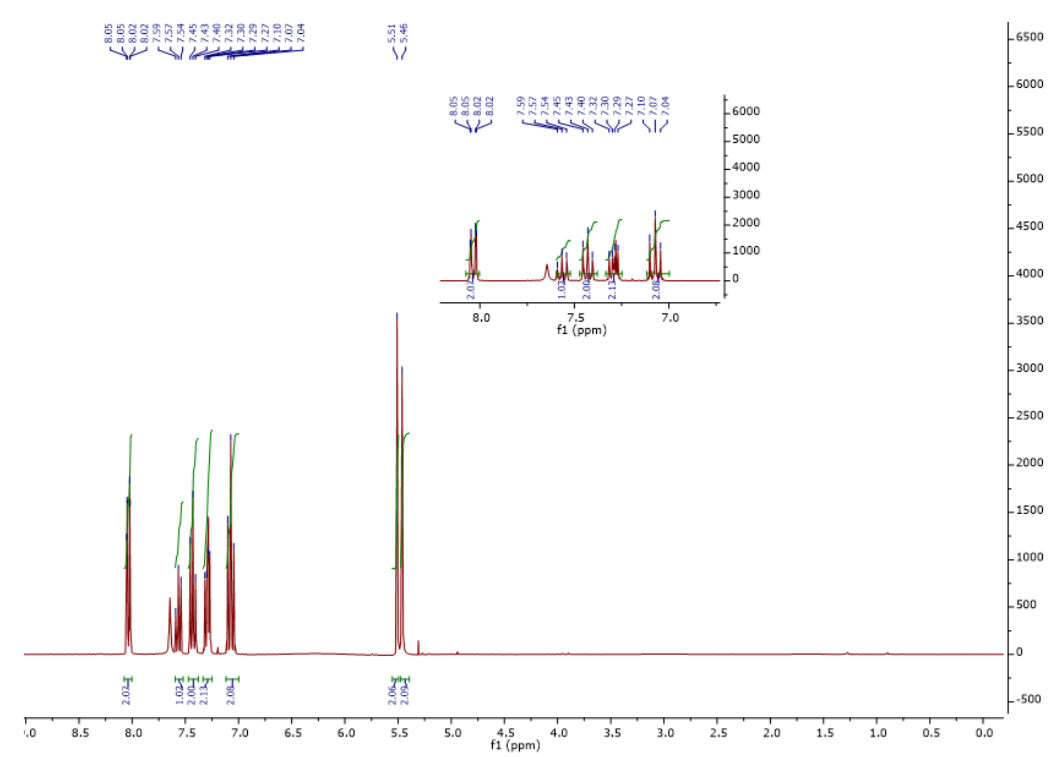



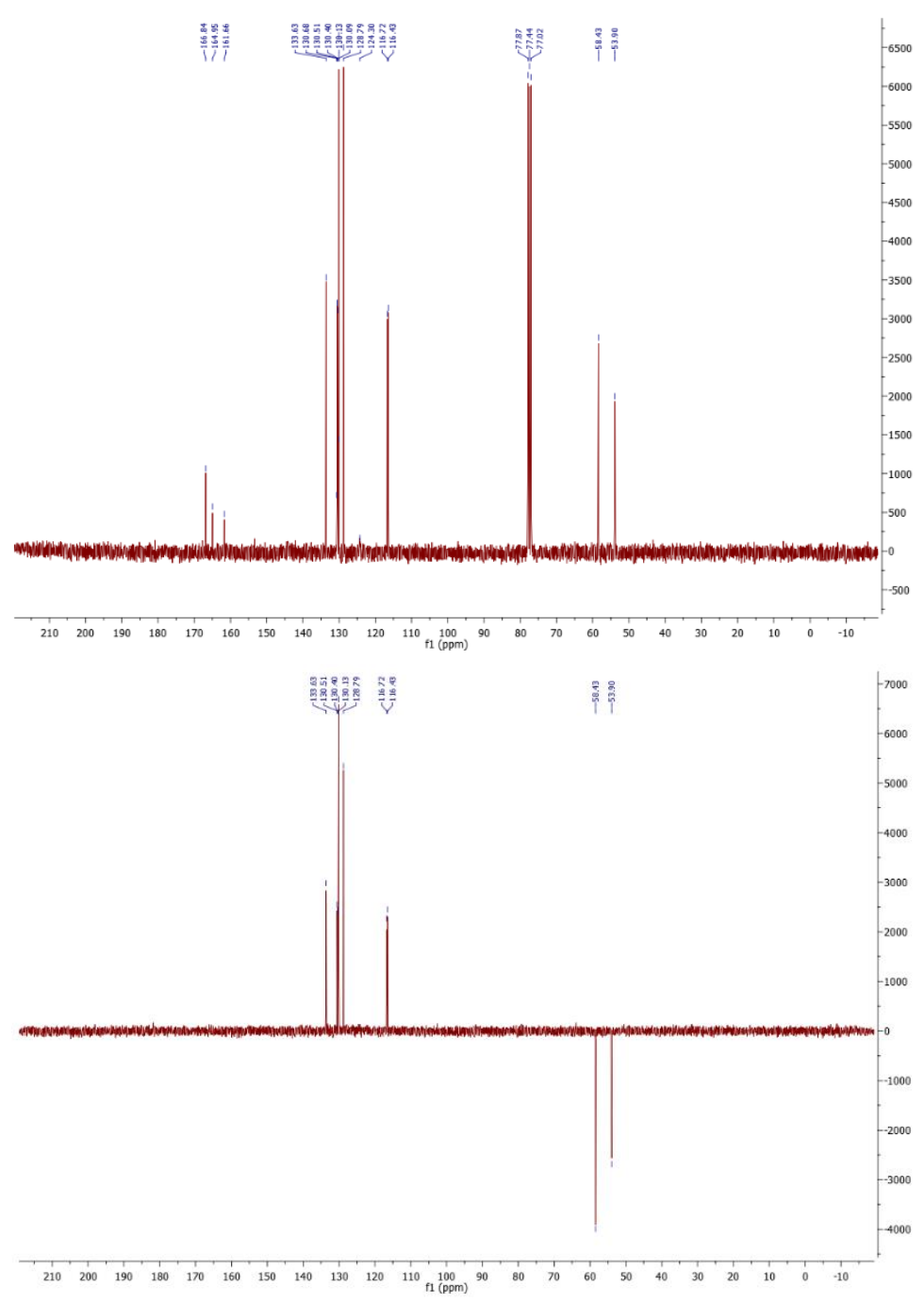

Figure S28. The spectrums NMR proton, Carbone, and Dept 135 of Product 10.

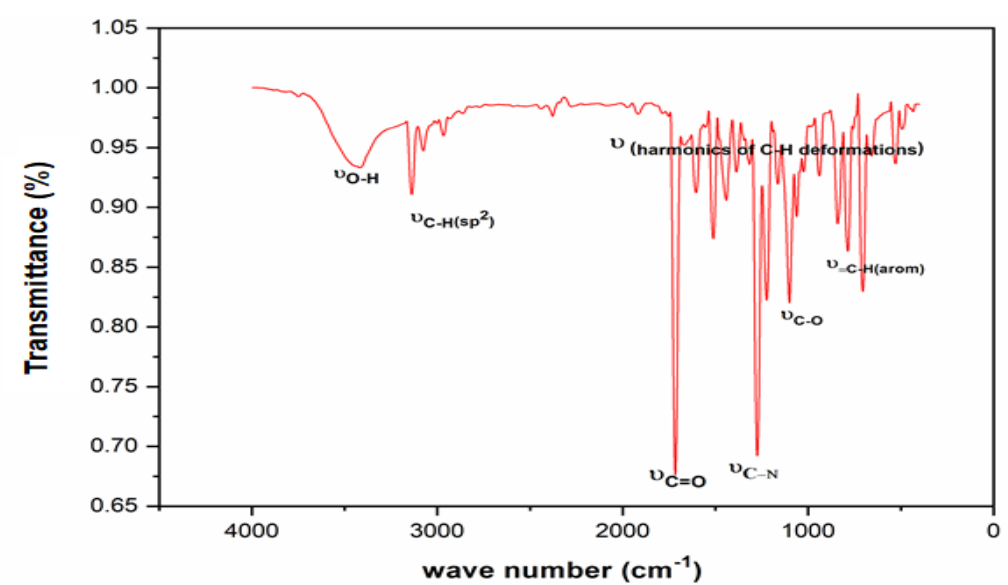

Figure S29. FT-IR absorption spectrum of Product 10. 


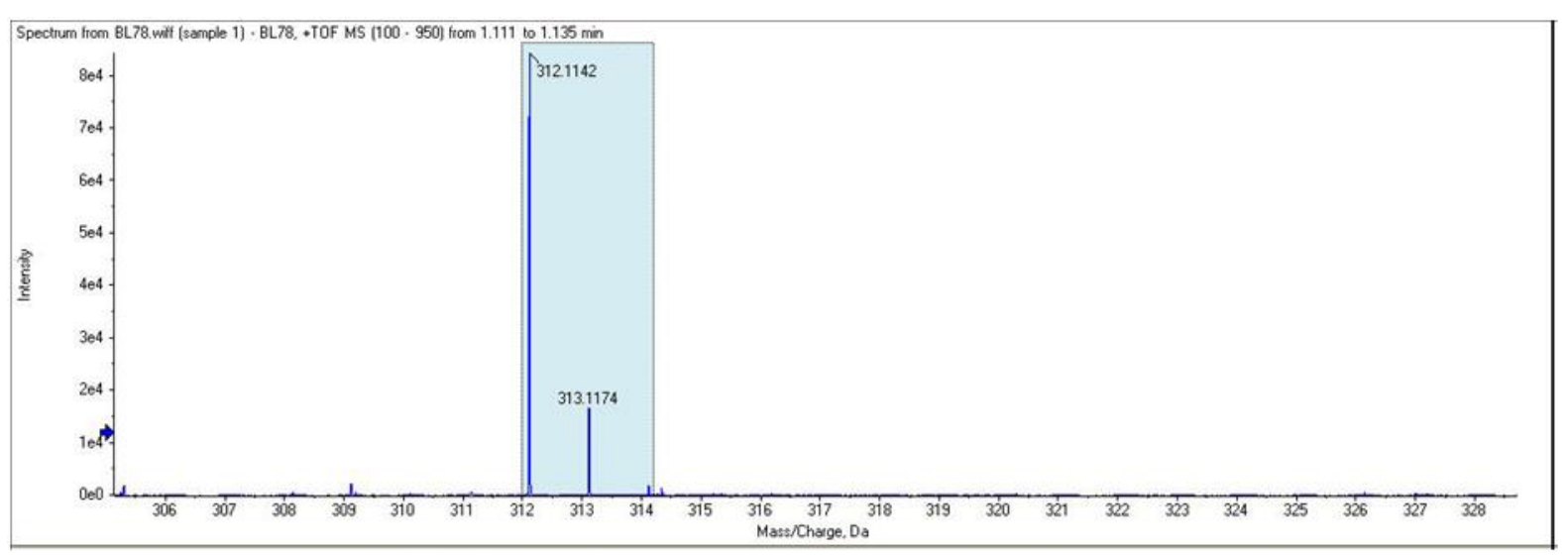

Figure S30. The spectrum HRMS of Product 10. 